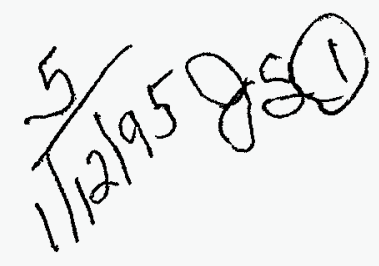

UCRL-ID- 119129

\title{
Molten Salt Destruction of Rubber and Chlorinated Solvents
}

\author{
Ravindra S. Upadhye \\ John G. Wilder
}

September 1994

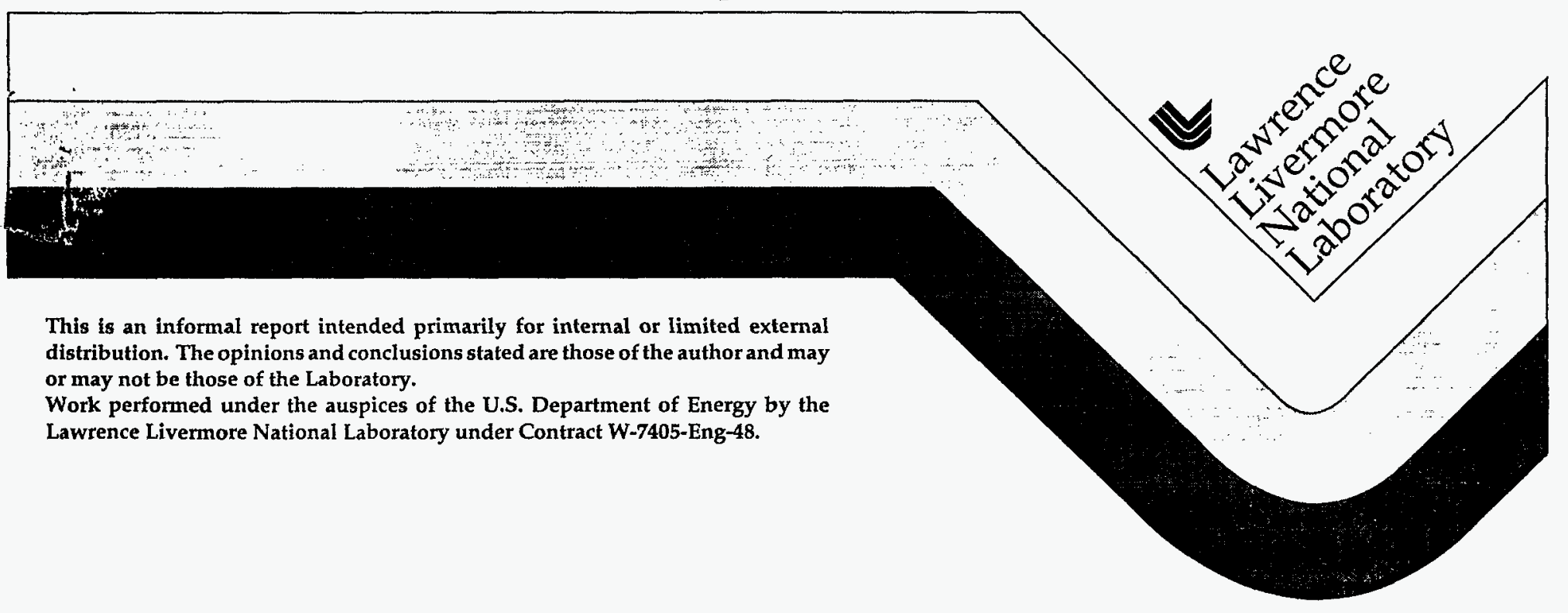




\section{DISCLAIMER}

This report was prepared as an account of work sponsored by an agency of the United States Government. Neither the United States Government nor any agency thereof, nor any of their employees, make any warranty, express or implied, or assumes any legal liability or responsibility for the accuracy, completeness, or usefulness of any information, apparatus, product, or process disclosed, or represents that its use would not infringe privately owned rights. Reference herein to any specific commercial product, process, or service by trade name, trademark, manufacturer, or otherwise does not necessarily constitute or imply its endorsement, recommendation, or favoring by the United States Government or any agency thereof. The views and opinions of authors expressed herein do not necessarily state or reflect those of the United States Government or any agency thereof. 


\section{DISCLAIMER}

Portions of this document may be illegible in electronic image products. Images are produced from the best available original document. 


\title{
MOLTEN SALT DESTRUCTION OF RUBBER AND CHLORINATED SOLVENTS
}

Ravindra S. Upadhye and John G. Wilder Lawrence Livermore National Laboratory

\begin{abstract}
Molten Salt Destruction (MSD) is an alternative to, and offers several advantages over, incineration. We have demonstrated the viability of the MSD process to cleanly destroy rubber and chlorinated solvents.
\end{abstract}

\section{INTRODUCTION}

Acceptable methods for the treatment of mixed wastes are not currently available. We have investigated Molten Salt Destruction (MSD) as an alternative to incineration of mixed wastes. MSD was originally developed by Rockwell International as a single stage process for coal gasification, and later used for treatment of hazardous wastes such as PCB's. MSD differs from incineration in several ways: there is no evidence of open flames in MSD, the containment of actinides is accomplished by chemical means (wetting and dissolution), the operating temperature of MSD is much lower $\left(700-950^{\circ} \mathrm{C}\right.$ vs. $\left.1000-1200^{\circ} \mathrm{C}\right)$ thus lowering the volatility of actinides. Furthermore, no acid gases are released from MSD. These advantages provide the main incentive for developing MSD as an alternative to incineration.

In MSD, wastes are introduced with air or oxygen into a bed of molten salt (typically alkali metal carbonate). In this environment, the organic components of the mixed waste are converted into $\mathrm{CO}_{2}$ and $\mathrm{H}_{2} \mathrm{O}$, heteroatoms such as chlorine form stable salts (e.g., sodium chloride), and the actinides remain in the melt (either dissolved into the melt or as a separate phase). The lower operating temperature of the process $\left(700-950^{\circ} \mathrm{C}\right.$, compared to $1000-1200^{\circ} \mathrm{C}$ for incineration) keeps the actinide volatility low. The products of the MSD process are some combination of benign gases $\left(\mathrm{CO}_{2}, \mathrm{H}_{2} \mathrm{O}\right)$, concentrated actinide oxides/salts, and low level waste, resulting in a large volume reduction from the original mixed waste. Treatable waste streams consist of organic liquids (including those containing chlorinated solvents and PCB's), greases, and combustible solids such as cellulosic matter, rubber and plastics. The experiments reported here were the first demonstration of solid waste and halogen solvent destruction by the MSD process. 


\section{SUMMARY}

We have demonstrated the viability of the MSD process to cleanly destroy rubber and chlorinated solvents. A schmatic of the apparatus which was designed and built at LLNL is shown in Figure 1. Vulcanized rubber was selected as the surrogate organic solid waste because of its relatively high chemical durability. It is also a constituent of glove box waste and other low level radioactive waste, and its decomposition products are environmentally offensive if not completely mineralized. - Our supply was obtained from a local tire recapping shop. Rubber crumbs were fed into the vessel utilizing a gas-tight screw feed apparatus as shown in Figure 2. This equipment was modified at LLNL for handling oil shale and proved to be ideal for rubber, as well. The rubber crumbs were fed into the combustion air stream directly without the use of any liquid slurry intermediates.

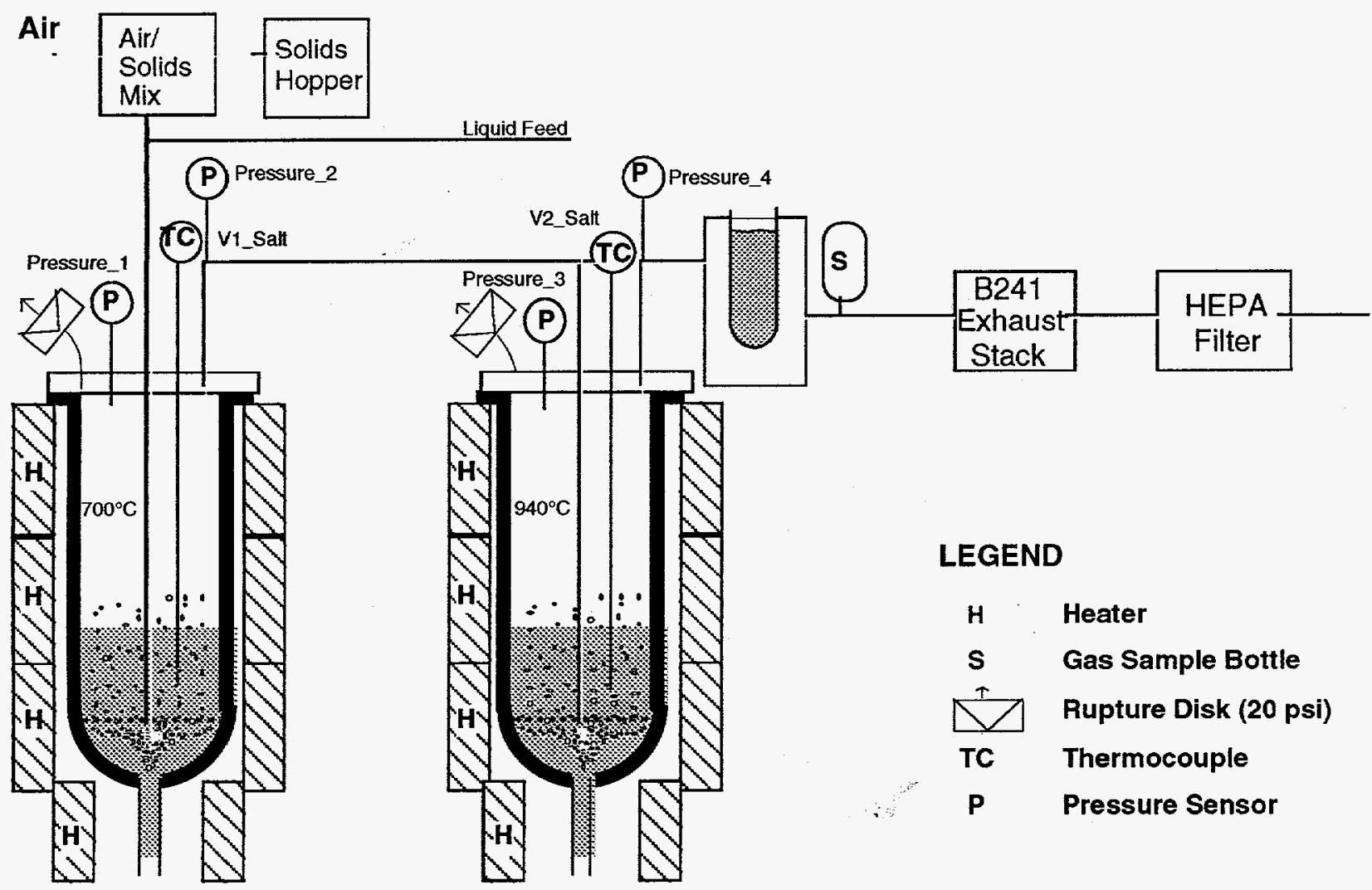

Figure 1. Schematic of Molten Salt Destruction apparatus. 


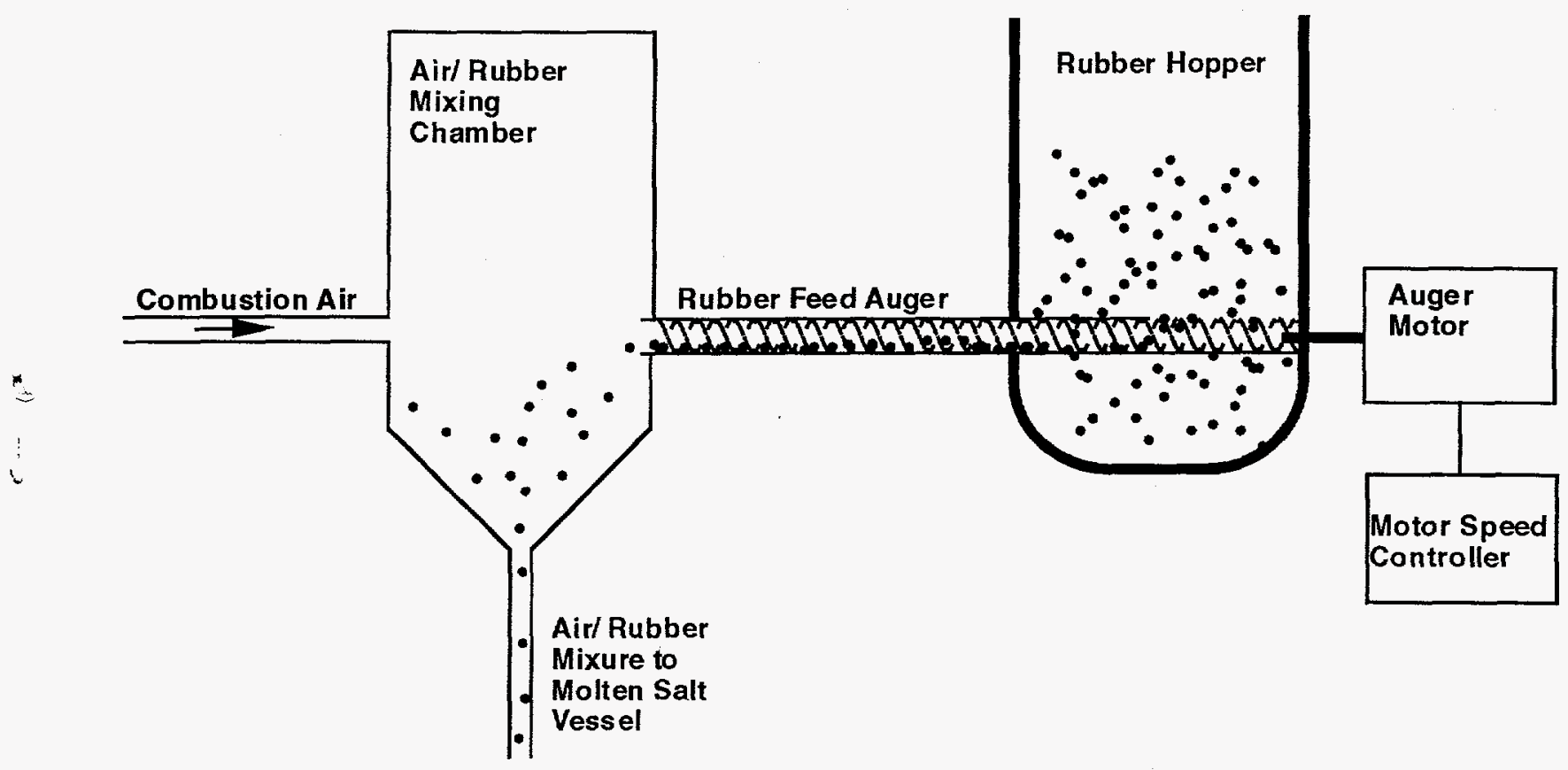

Figure 2. Schematic of screw feed apparatus.

A series of experiments were completed in September 1993 in which approximately 30 kilograms of rubber and a variety of chlorinated solvents were destroyed. The combustion gas/rubber mixture was injected directly into the molten salt. The destruction was completed using the apparatus in a two stage configuration under oxidizing conditions. The two stages were maintained at $700^{\circ} \mathrm{C}$ and $940^{\circ} \mathrm{C}$, respectively. Exhaust gas samples were taken at four hour intervals. The longest continuous run operated for 85 hours consuming 12 kilograms of rubber. Gas analysis of the dry exhaust identified nitrogen, carbon dioxide, oxygen, and argon as the major components. Carbon monoxide, hydrogen, and nitric oxide were detected in minor quantities $(0.4 \%$ maximum) in some samples. Minor constituents were undetected in about one third of the gas samples. Destruction of chlorinated solvents was also demonstrated. Trichloroethylene, chloroform, carbon tetrachloride, 1-chloronapthalene, 1,2-dichloroethane, and chlorobenzene were destroyed. These compounds were selected primarily because of the immediate availability in local chemical storage cabinets. However, they also represent a good cross section of chlorinated solvents in industrial use. Exhaust gas analysis showed only carbon dioxide, nitrogen, argon, and oxygen. There was no trace of any other gas. The destruction of these materials appeared to be complete. 


\section{MSD Equipment}

\section{EXPERIMENT}

The corrosive characteristic of molten salt coupled with uncertainty of the received waste form in a "real world" operation dictates a simple robust design. The two crucibles, physically identical, are made of 304 stainless steel. They are 5.76 inches inside diameter, 6.63 inches outside diameter, 37.75 inches long, and fitted with a drain pipe at the bottom and a flange on the top. The drain pipe leads to a retention bucket, large enough to contain the molten salt inventory, which is placed under each crucible. Three cylindrical electric heaters, each rated at $3 \mathrm{~kW}$, surround each crucible. Waste and combustion air are introduced through a $13 / 8$ inch diameter feed tube near the center of both crucibles. Each tube extends below the salt surface to about one inch above the crucible bottom. After percolating through the first crucible, the gaseous product is sent to the second crucible to assure complete oxidation. Additional combustion gas for the second crucible can be introduced separately into the second feed tube, if desired. All combustion gas was introduced into the first vessel during the rubber destruction experiments; while $25 \%$ of the combustion gas was utilized in stage one with the remainder going directly to stage two for the chlorinated solvent destruction experiments. Off-gas from the second crucible passes through a cold trap (i.e., water finger near room temperature) to capture entrained liquid droplets and salt vapor prior to discharge into a ventilation hood. Samples of the dry off-gas are collected via a sample port downstream of the cold trap.

The two vessels and the connecting piping are instrumented to monitor temperature and pressure. Thermocouple readouts monitor the salt temperature in each vessel and the temperature of each vessel wall at three elevations. The elevations (low, middle, and high) correspond to each heater. There are additional thermocouples employed in the automatic temperature controller feedback loop for each heater and are independent of the readout monitor. We use a data logger/controller program to continuously save the data and to control the operation of the unit. Because the temperature control units do not monitor the same thermocouple that the operator observes, there can be a discrepancy between the set point temperature of the controller and the observed steady state temperature of the vessel. The set points were subordinated to maintain the desired temperatures on the operator readouts. Four pressure transducers are employed. Pressure is monitored in each vessel and with in each exhaust line. The system is designed to 
operate at near atmospheric pressure. Pressure increases indicate the location of impending blockages. Each vessel is fitted with an independent burst disk set at 22 psig. This disk will rupture and vent if the system becomes blocked and corrective action is neglected. Gas samples can be taken through a number of sampling ports for off-line analysis.

\section{Experimental Procedure}

All temperatures and pressures are timed stamped and recorded every 20 seconds. The heaters are used to raise the MSD vessel temperatures to the desired level. The procedure is to heat the vessels to melt the salt and bring the salt to the desired temperatures. This was $700^{\circ} \mathrm{C}$ and $940^{\circ} \mathrm{C}$ for vessels one and two, respectively. When the combustion gas was introduced, temperatures and gas flow were allowed to stabilize. At this point the waste feed was started. For the rubber destruction experiments, we sieved the rubber through a \#10 sieve prior to loading it into the screw-feed hopper. The hopper capacity is about two kilograms. The screw-feed apparatus is controlled by a variable speed controller set to deliver three grams per minute. Combustion gas is supplied from the building compressed air source and was passed through a mass flow meter, a flow control valve, and into the screw-feed discharge chamber where it collects the rubber shavings from the feed discharge and blows the shavings into the MSD first stage injection tube. The airflow is set to $1.6 \mathrm{scfm}$ (standard cubic feet per minute) or $120 \%$ of the stoichiometric requirement for theoretical complete combustion. We assumed the empirical chemical formula of a saturated hydrocarbon $\left(\left(\mathrm{CH}_{2}\right)_{n}\right)$ as the formula for rubber for this calculation. For the chlorinated solvent destruction experiments, the solvent was delivered into vessel one via a separate liquid feed line "teed" into the combustion air supply just above the injection line. The solvents were delivered by a positive displacement pump set at $3.4 \mathrm{ml} / \mathrm{min}$ (milliliters per minute). The combustion air was $0.5 \mathrm{scfm}$. An additional $1.5 \mathrm{scfm}$ of combustion air was supplied to the first stage exhaust for injection into the second vessel. Time logs and gas samples were collected. Gas was sampled from a port downstream of the cold trap and held for later analysis.

\section{Exhaust Gas Analysis}

Exhaust gas samples were collected in 50 milliliter bottles and analyzed using mass spectroscopy. Collection bottles were 316 Stainless Steel fitted with a leak tight valve and tubing connection. The bottles were evacuated at elevated temperature, the valve shut, and stored until required for sample collection. Sample collection 
was simply connecting the bottle via its tube fitting to the sample port, opening the valve for 10 seconds, shutting the valve, disconnecting the tube fitting, and transporting the filled bottle to the analytical laboratory. A gas mass spectrometer was used for all analysis. A broad range mass analysis for all species up to mass number 200 was performed. The detection limit for species of interest was 50 parts per million or $0.005 \%$.

\section{RESULTS}

The data for all experiments can be found in Appendix B. Below is a brief description of the results for each experiment listed by the completion date.

22 June 1993 - Solvent Destruction

Experimental Conditions:

\begin{tabular}{|c|c|c|c|c|}
\hline $\begin{array}{c}\text { Combustion } \\
\text { Air Flow } \\
(\mathrm{scfm})\end{array}$ & $\begin{array}{c}\text { Solvent feed } \\
(\mathrm{ml} / \mathrm{min})\end{array}$ & $\begin{array}{c}\text { Exhaust Gas } \\
\text { Samples } \\
\text { Taken }\end{array}$ & $\begin{array}{c}\text { First Stage } \\
\text { Salt Temp. } \\
\left({ }^{\circ} \mathrm{C}\right)\end{array}$ & $\begin{array}{c}\text { Second Stage } \\
\text { Salt Temp. } \\
\left({ }^{\circ} \mathrm{C}\right)\end{array}$ \\
\hline 2.0 & 3.4 & 1 each & 710 & 900 \\
\hline
\end{tabular}

Results:

\begin{tabular}{|c|c|c|c|c|c|c|}
\hline Solvent & $\% \mathrm{O}_{2}$ & $\% \mathrm{CO}_{2}$ & $\% \mathrm{CO}$ & $\% \mathrm{NO}_{x}$ & $\% \mathrm{~N}_{2}$ & $\% \mathrm{Ar}$ \\
\hline Tricloroethylene & 17.10 & 4.30 & $<.005$ & $<.005$ & 77.70 & 0.91 \\
\hline 1,2-dichloroethane & 15.49 & 5.41 & $<.005$ & $<.005$ & 78.18 & 0.91 \\
\hline Chlorobenzene & 11.87 & 8.29 & $<.005$ & $<.005$ & 78.93 & 0.92 \\
\hline 1-chloronaphthalene & 14.19 & 5.28 & $<.005$ & $<.005$ & 79.60 & 0.93 \\
\hline Chloroform & 18.10 & 3.49 & $<.005$ & $<.005$ & 77.50 & 0.91 \\
\hline Carbon tetrachloride & 19.76 & 3.54 & $<.005$ & $<.005$ & 75.82 & 0.88 \\
\hline
\end{tabular}

Discussion:

The above table gives the general conditions for six different chlorinated solvent destruction experiments. The solvent was either trichloroethylene, chloroform, carbon tetrachloride, 1-chloronapthalene, 1,2-dichloroethane, or chlorobenzene. Each run lasted approximately 30 minutes. All gas analysis showed only nitrogen, oxygen, argon, and carbon dioxide. The oxygen was highest and the carbon dioxide lowest in the solvents having the least carbon content (carbon tetrachloride). There were no surprises here, only a confirmation of what was predicted. Destruction efficiency of these materials approaches $100 \%$; no products of incomplete combustion were detected. 


\section{September 1993 - Rubber Destruction}

Experimental Conditions:

\begin{tabular}{|c|c|c|c|c|}
\hline $\begin{array}{c}\text { Combustion } \\
\text { Air Flow } \\
(\mathrm{scfm})\end{array}$ & $\begin{array}{c}\text { Rubber Feed } \\
(\mathrm{g} / \mathrm{min})\end{array}$ & $\begin{array}{c}\text { Exhaust Gas } \\
\text { Samples } \\
\text { Taken }\end{array}$ & $\begin{array}{c}\text { First Stage } \\
\text { Salt Temp. } \\
\left({ }^{\circ} \mathrm{C}\right)\end{array}$ & $\begin{array}{c}\text { Second Stage } \\
\text { Salt Temp. } \\
\left({ }^{\circ} \mathrm{C}\right)\end{array}$ \\
\hline 2.5 & 5.5 & 1 & $705-758$ & $705-730$ \\
\hline
\end{tabular}

Results:

\begin{tabular}{|c|c|c|c|c|c|c|}
\hline Feed Material & $\% \mathrm{O}_{2}$ & $\% \mathrm{CO}_{2}$ & $\% \mathrm{CO}$ & $\% \mathrm{NO}_{\mathrm{x}}$ & $\% \mathrm{~N}_{2}$ & $\% \mathrm{Ar}$ \\
\hline Vulcanized Rubber & 10.18 & 7.05 & $<.005$ & $<.005$ & 81.80 & 0.97 \\
\hline
\end{tabular}

Discussion:

This short "shakedown" run was discontinued due to blockage of the air-rubber supply line. It was terminated after less than two hours. Gas analysis showed only the expected major components.

\section{September 1993 - Rubber Destruction}

Experimental Conditions:

\begin{tabular}{|c|c|c|c|c|}
\hline $\begin{array}{c}\text { Combustion } \\
\text { Air Flow } \\
(\mathrm{scfm})\end{array}$ & $\begin{array}{c}\text { Rubber Feed } \\
(\mathrm{g} / \mathrm{min})\end{array}$ & $\begin{array}{c}\text { Exhaust Gas } \\
\text { Samples } \\
\text { Taken }\end{array}$ & $\begin{array}{c}\text { First Stage } \\
\text { Salt Temp. } \\
\left({ }^{\circ} \mathrm{C}\right)\end{array}$ & $\begin{array}{c}\text { Second Stage } \\
\text { Salt Temp. } \\
\left({ }^{\circ} \mathrm{C}\right)\end{array}$ \\
\hline 2.5 & 5.5 & 4 & $785-688$ & $721-744$ \\
\hline
\end{tabular}

Results:

\begin{tabular}{|c|c|c|c|c|c|c|c|}
\hline Feed Material & $\% \mathrm{O}_{2}$ & $\% \mathrm{CO}_{2}$ & $\% \mathrm{CO}$ & $\% \mathrm{NO}_{x}$ & $\% \mathrm{~N}_{2}$ & $\% \mathrm{Ar}$ & $\% \mathrm{H}_{2}$ \\
\hline Vulcanized Rubber & 6.88 & 11.66 & $<.005$ & $<.005$ & 80.23 & 0.95 & - \\
\hline Vulcanized Rubber & 6.55 & 11.92 & $<.005$ & $<.005$ & 80.25 & 0.95 & - \\
\hline Vulcanized Rubber & 7.68 & 10.95 & $<.005$ & $<.005$ & 80.00 & 0.95 & 0.09 \\
\hline Vulcanized Rubber & 13.05 & 6.39 & $<.005$ & $<.005$ & 79.61 & 0.94 & - \\
\hline Vulcanized Rubber & 14.29 & 5.47 & $<.005$ & $<.005$ & 79.13 & 0.94 & - \\
\hline
\end{tabular}

Discussion:

This experiment lasted five hours. There were no plugging problems. We initiated sieving the rubber crumbs to correct the blocking problem experienced in the previous day's run. The first stage vessel was operated above $780^{\circ} \mathrm{C}$ for most of 
the run. The second stage never exceeded $750^{\circ} \mathrm{C}$. All gas samples were found to contain carbon monoxide at up to $0.3 \%$ vol./vol. If destruction efficiency is defined as product detected in the exhaust stream divided by total product injected into the MSD unit, then destruction efficiency was $100 \%$. (Rubber is not volatile and it is doubtful that any would be detected in an exhaust gas sample.) If, however, destruction efficiency includes all compounds of carbon other than carbon dioxide, and the quantity of these products is compared to that of carbon dioxide, then the destruction efficiency is approximately $97 \%$ for this run.

\section{September 1993 - Rubber Destruction}

Experimental Conditions:

\begin{tabular}{|c|c|c|c|c|}
\hline $\begin{array}{c}\text { Combustion } \\
\text { Air Flow } \\
(\mathrm{scfm})\end{array}$ & $\begin{array}{c}\text { Rubber Feed } \\
(\mathrm{g} / \mathrm{min})\end{array}$ & $\begin{array}{c}\text { Exhaust Gas } \\
\text { Samples } \\
\text { Taken }\end{array}$ & $\begin{array}{c}\text { First Stage } \\
\text { Salt Temp. } \\
\left({ }^{\circ} \mathrm{C}\right)\end{array}$ & $\begin{array}{c}\text { Second Stage } \\
\text { Salt Temp. } \\
\left({ }^{\circ} \mathrm{C}\right)\end{array}$ \\
\hline 1.8 & 4.7 & 1 & $675-850$ & $540-920$ \\
\hline
\end{tabular}

Results:

\begin{tabular}{|c|c|c|c|c|c|c|}
\hline Feed Material & $\% \mathrm{O}_{2}$ & $\% \mathrm{CO}_{2}$ & $\% \mathrm{CO}$ & $\% \mathrm{NO}_{\mathrm{x}}$ & $\% \mathrm{~N}_{2}$ & $\% \mathrm{Ar}$ \\
\hline Vulcanized Rubber & 4.98 & 14.18 & 0.65 & 0.94 & 79.21 & 0.94 \\
\hline
\end{tabular}

Discussion:

This experiment was intended to test the result of sub-stoichiometric (90\%) air supply to the first stage vessel. The system was plagued by blockage problems in the rubber feed system that had not been experienced in the previous experiment. The gas analysis showed $0.65 \%$ carbon monoxide and, surprisingly, $0.044 \%$ nitrous oxide. Using the previous carbon compounds ratio to carbon dioxide, this equates to a destruction efficiency of $96 \%$.

\section{September 1993 - Rubber Destruction}

Experimental Conditions:

\begin{tabular}{|c|c|c|c|c|}
\hline $\begin{array}{c}\text { Combustion } \\
\text { Air Flow } \\
(\mathrm{scfm})\end{array}$ & $\begin{array}{c}\text { Rubber Feed } \\
(\mathrm{g} / \mathrm{min})\end{array}$ & $\begin{array}{c}\text { Exhaust Gas } \\
\text { Samples } \\
\text { Taken }\end{array}$ & $\begin{array}{c}\text { First Stage } \\
\text { Salt Temp. } \\
\left({ }^{\circ} \mathrm{C}\right)\end{array}$ & $\begin{array}{c}\text { Second Stage } \\
\text { Salt Temp. } \\
\left({ }^{\circ} \mathrm{C}\right)\end{array}$ \\
\hline 1.5 & 3.0 & 10 & $670-710$ & $926-936$ \\
\hline
\end{tabular}


Results:

\begin{tabular}{|c|c|c|c|c|c|c|}
\hline Feed Material & $\% \mathrm{O}_{2}$ & $\% \mathrm{CO}_{2}$ & $\% \mathrm{CO}$ & $\% \mathrm{NO}_{\mathrm{x}}$ & $\% \mathrm{~N}_{2}$ & $\% \mathrm{Ar}$ \\
\hline Vulcanized Rubber & 8.36 & 10.36 & 0.26 & $<.005$ & 80.06 & 0.95 \\
\hline Vulcanized Rubber & 8.76 & 9.98 & 0.22 & $<.005$ & 80.08 & 0.95 \\
\hline Vulcanized Rubber & 10.34 & 8.30 & $<.005$ & 0.01 & 80.40 & 0.95 \\
\hline Vulcanized Rubber & 17.94 & 2.89 & $<.005$ & 0.01 & 78.22 & 0.93 \\
\hline Vulcanized Rubber & 12.86 & 6.88 & $<.005$ & 0.01 & 79.30 & 0.94 \\
\hline Vulcanized Rubber & 10.62 & 8.55 & 0.20 & 0.07 & 79.81 & 0.95 \\
\hline Vulcanized Rubber & 9.74 & 9.20 & $<.005$ & 0.07 & 79.85 & 0.95 \\
\hline Vulcanized Rubber & 10.57 & 8.71 & $<.005$ & $<.005$ & 79.77 & 0.94 \\
\hline Vulcanized Rubber & 8.20 & 10.64 & $<.005$ & 0.01 & 80.20 & 0.95 \\
\hline Vulcanized Rubber & 10.74 & 8.46 & $<.005$ & 0.01 & 79.84 & 0.94 \\
\hline
\end{tabular}

Discussion:

This run lasted 39 hours. It was plagued in the early stages by routine plugging of the rubber particles in the supply line. This resulted in numerous short duration stops to unplug the line and continue the feed. Ten hours into the run the 1/4 inch feed line was replaced by a $3 / 8$ inch line. This solved the plugging problem. The gas analysis results showed small amounts (up to $0.25 \%$ ) of carbon monoxide in three of the ten gas samples. Trace amounts of nitrous and nitric oxide were also detected in some of the samples. The pressure in vessel one began to rise, prompting a controlled shutdown. Subsequent inspection showed salt buildup in the exhaust riser line of vessel one. Overall destruction efficiency exceeded $99 \%$.

\section{September 1993 - Rubber Destruction}

Experimental Conditions:

\begin{tabular}{|c|c|c|c|c|}
\hline $\begin{array}{c}\text { Combustion } \\
\text { Air Flow } \\
(\mathrm{scfm})\end{array}$ & $\begin{array}{c}\text { Rubber Feed } \\
(\mathrm{g} / \mathrm{min})\end{array}$ & $\begin{array}{c}\text { Exhaust Gas } \\
\text { Samples } \\
\text { Taken }\end{array}$ & $\begin{array}{c}\text { First Stage } \\
\text { Salt Temp. } \\
\left({ }^{\circ} \mathrm{C}\right)\end{array}$ & $\begin{array}{c}\text { Second Stage } \\
\text { Salt Temp. } \\
\left({ }^{\circ} \mathrm{C}\right)\end{array}$ \\
\hline 1.6 & 3.0 & 19 & $690-722$ & $930-937$ \\
\hline
\end{tabular}

Results:

\begin{tabular}{|c|c|c|c|c|c|c|c|}
\hline Feed Material & $\% \mathrm{O}_{2}$ & $\% \mathrm{CO}_{2}$ & $\% \mathrm{CO}$ & $\% \mathrm{NO}_{\mathrm{x}}$ & $\% \mathrm{~N}_{2}$ & $\% \mathrm{Ar}$ & $\% \mathrm{He}$ \\
\hline Vulcanized Rubber & 9.64 & 8.48 & 0.18 & 0.01 & 80.78 & 0.91 & - \\
\hline Vulcanized Rubber & 10.71 & 8.16 & 0.23 & 0.01 & 79.98 & 0.90 & - \\
\hline
\end{tabular}




\begin{tabular}{|l|c|c|c|c|c|c|c|}
\hline Vulcanized Rubber & 8.99 & 9.28 & 0.27 & $<.005$ & 80.55 & 0.91 & - \\
\hline Vulcanized Rubber & 8.66 & 9.55 & 0.26 & 0.01 & 80.60 & 0.91 & - \\
\hline Vulcanized Rubber & 10.24 & 8.17 & 0.23 & $<.005$ & 80.45 & 0.91 & - \\
\hline Vulcanized Rubber & 9.44 & 8.89 & 0.29 & 0.01 & 80.46 & 0.91 & - \\
\hline Vulcanized Rubber & 7.19 & 10.30 & 0.40 & 0.01 & 81.18 & 0.92 & - \\
\hline Vulcanized Rubber & 8.05 & 9.89 & $<.005$ & 0.02 & 81.16 & 0.91 & - \\
\hline Vulcanized Rubber & 11.16 & 7.33 & $<.005$ & $<.005$ & 80.61 & 0.89 & - \\
\hline Vulcanized Rubber & 10.87 & 7.44 & 0.19 & $<.005$ & 80.60 & 0.89 & - \\
\hline Vulcanized Rubber & 5.59 & 11.52 & $<.005$ & $<.005$ & 81.98 & 0.91 & - \\
\hline Vulcanized Rubber & 9.59 & 8.61 & 0.11 & 0.01 & 80.79 & 0.90 & - \\
\hline Vulcanized Rubber & 11.28 & 7.37 & 0.12 & $<.005$ & 80.33 & 0.89 & - \\
\hline Vulcanized Rubber & 10.26 & 8.07 & $<.005$ & $<.005$ & 80.74 & 0.90 & .030 \\
\hline Vulcanized Rubber & 10.87 & 7.47 & $<.005$ & $<.005$ & 80.77 & 0.89 & - \\
\hline Vulcanized Rubber & 11.66 & 6.94 & $<.005$ & $<.005$ & 80.51 & 0.89 & - \\
\hline Vulcanized Rubber & 12.65 & 6.14 & $<.005$ & $<.005$ & 80.32 & 0.89 & - \\
\hline Vulcanized Rubber & 11.25 & 7.13 & $<.005$ & $<.005$ & 80.71 & 0.89 & - \\
\hline Vulcanized Rubber & 10.19 & 8.09 & $<.005$ & $<.005$ & 80.81 & 0.90 & - \\
\hline
\end{tabular}

Discussion:

This experiment lasted 89 hours and was the longest continuous run of the series. The previous run was terminated sooner than intended due to salt buildup in the exhaust riser lines adjacent to the vessels. The plan was to "feel" the condition of the exhaust riser at periodic intervals using a tempered wire through an access port at the top of each riser. When a measurable quantity of salt was detected, the run would be stopped, an oxy-acetylene torch used to quickly melt the salt back into the vessel, and the run continued. This seemed reasonable in theory but was impractical in practice. The "wire feel" assessment was performed at four hour intervals but no salt build up was detected. The blockage that subsequently resulted was detected not by the wire, but rather by an increase in vessel pressure after about 86 hours into the run. The blockage seemed to occur over a very short time scale. Attempts to clear the line using the torch proved unsuccessful and the run was terminated. Analysis results of the gas samples followed the pattern established in the previous runs. Eight of the nineteen samples contained no detectable level of the minor constituent gases, the remaining samples showed small amounts of carbon monoxide, nitrous oxide, and nitric oxide in proportions found in earlier runs. Destruction efficiency equaled $98.6 \%$. 


\section{September 1993 - Rubber Destruction}

Experimental Conditions:

\begin{tabular}{|c|c|c|c|c|}
\hline $\begin{array}{c}\text { Combustion } \\
\text { Air Flow } \\
(\mathrm{scfm})\end{array}$ & $\begin{array}{c}\text { Rubber Feed } \\
(\mathrm{g} / \mathrm{min})\end{array}$ & $\begin{array}{c}\text { Exhaust Gas } \\
\text { Samples } \\
\text { Taken }\end{array}$ & $\begin{array}{c}\text { First Stage } \\
\text { Salt Temp. } \\
\left({ }^{\circ} \mathrm{C}\right)\end{array}$ & $\begin{array}{c}\text { Second Stage } \\
\text { Salt Temp. } \\
\left({ }^{\circ} \mathrm{C}\right)\end{array}$ \\
\hline 1.6 & 3.0 & 4 & $680-712$ & $930-940$ \\
\hline
\end{tabular}

Results:

\begin{tabular}{|c|c|c|c|c|c|c|}
\hline Feed Material & $\% \mathrm{O}_{2}$ & $\% \mathrm{CO}_{2}$ & $\% \mathrm{CO}$ & $\% \mathrm{NO}_{\mathrm{x}}$ & $\% \mathrm{~N}_{2}$ & $\% \mathrm{Ar}$ \\
\hline Vulcanized Rubber & 11.45 & 7.77 & $<.005$ & 0.06 & 79.78 & 0.93 \\
\hline Vulcanized Rubber & 11.26 & 7.59 & $<.005$ & 0.01 & 80.22 & 0.92 \\
\hline Vulcanized Rubber & 18.22 & 2.25 & $<.005$ & 0.01 & 78.62 & 0.90 \\
\hline
\end{tabular}

Discussion:

The final experiment in this series ran 28 hours. A steel wire brush was installed in the top of each exhaust line riser. The brush was welded to a steel shaft that extended through a sleeve and seal in the top of the riser. The intent was to physically clear the riser of salt deposits at regular intervals by running the brush the length of the pipe and into the top of the reaction vessel. Previous runs made it clear that the all blockages occurred in this region of the apparatus. We reasoned that a stiff wire scraper (in this case the wire brush) running the length of the pipe at regular intervals to push the preliminary salt deposits from the riser should allow a run of indefinite duration. Both risers were scraped at four hour intervals. This procedure worked as intended and the lines did not become blocked until the apparatus failed. The final attempt to clear the risers resulted in significant resistance to the brush movement in the riser of vessel one. When greater force was applied, the brush became irretrievably stuck in the top of vessel blocking the exhaust line. The run was then terminated. Four gas samples were taken but only three are reported (the forth was contaminated during analysis and disregarded). These three follow the trend established in the previous runs. There was no carbon monoxide detected in any of the samples. Destruction efficiency approached $100 \%$. 
Two Stage Molten Salt B-241 MSD 22 June $93 \quad$ MSD:DATA:MSD 22 June 93 TIMING REFERENCES-- VAX Time $=22$-JUN-1993 16:30:46.00, Decimal Hours = 16.5127778

6/23/93 9:10:13 AM 9.183056 General conditions for these experiments:

These experiments are to sample the combustion gases resulting from the destruction of dodecane, ethylene glycol, and a variety of chlorinated solvents.

The unit will operate in the two stage mode with the first stage at $700^{\circ} \mathrm{C}$ and the second stage at $950^{\circ} \mathrm{C}$. The first stage will be operated in a reducing mode and the second stage will be in an oxidizing mode. Combustion air to the first stage will be $0.5 \mathrm{scfm}$; air to the second stage will be $2.5 \mathrm{scfm}$. Fuel flow will be maintained at $5 \mathrm{cc}$ per minute. An additional $3.5 \mathrm{~kg}$ sodium carbonate and $3.0 \mathrm{~kg}$ potasium carbonate was added to the second stage vessel. Total second stage salt capacity is thought to be 11.5 to $13.5 \mathrm{~kg}$.

6/23/93 3:15:30 PM 15.286148 Change of plan: First stage injection is $0.5 \mathrm{scfm}$ combustion air and $3.4 \mathrm{cc} / \mathrm{min}$ fuel. Second stage combustion air is $1.5 \mathrm{scfm}$. First stage is $710^{\circ} \mathrm{C}$, Second stage is $900^{\circ} \mathrm{C}$.
$6 / 23 / 93$
3:16:35 PM
$6 / 23 / 93$
3:25:34 PM
15.304167
Gas Sample \#54: Dodecane
$6 / 23 / 93$
3:34:57 PM 15.610731
Gas Sample \#4: Ethylene glycol.
$6 / 23 / 93$
3:42:24 PM 15.735454
$6 / 23 / 93$
3:51:21 PM 15.885079
$6 / 23 / 93$
4:00:26 PM 16.036491
$6 / 23 / 93$
4:11:47 PM
16.226597
$6 / 23 / 93$
4:21:16 PM 16.385009
$6 / 23 / 93$
4:33:04 PM 16.581935
Gas sample \#43: Trichloroethylene.
Gas Sample \#57: Chloroform
Gas Sample \#3: Carbon tetrachloride.
Gas Sample \#56: 1-chloronapthalene.
Sample \#51: 1,2-dichloroethane
Sample \#55: Chlorobenzene.
Secure Experiment. 
Pressure (PSIA)

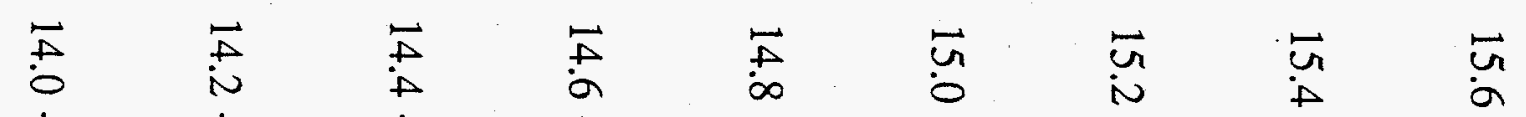

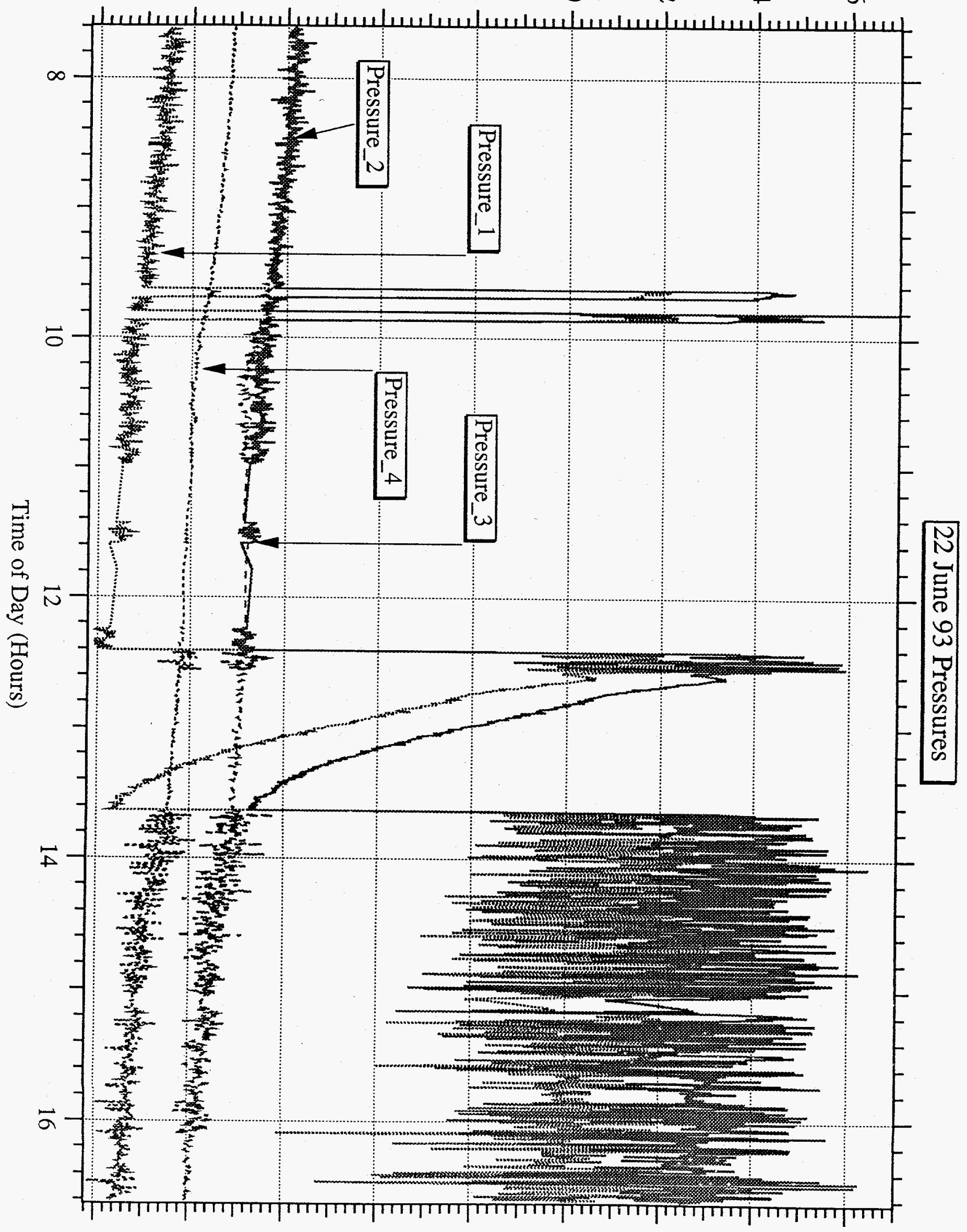




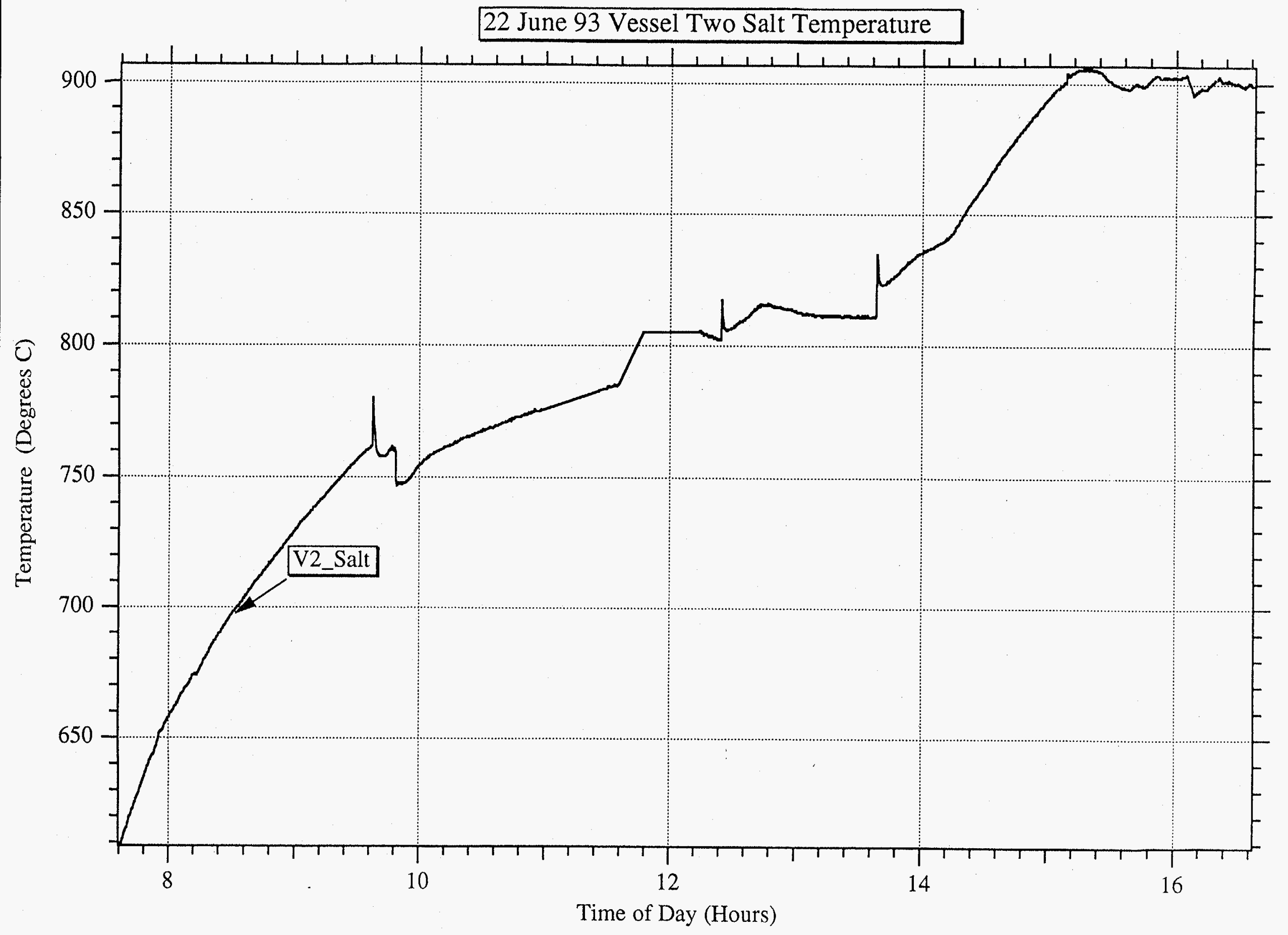


Temperature (Degrees C)

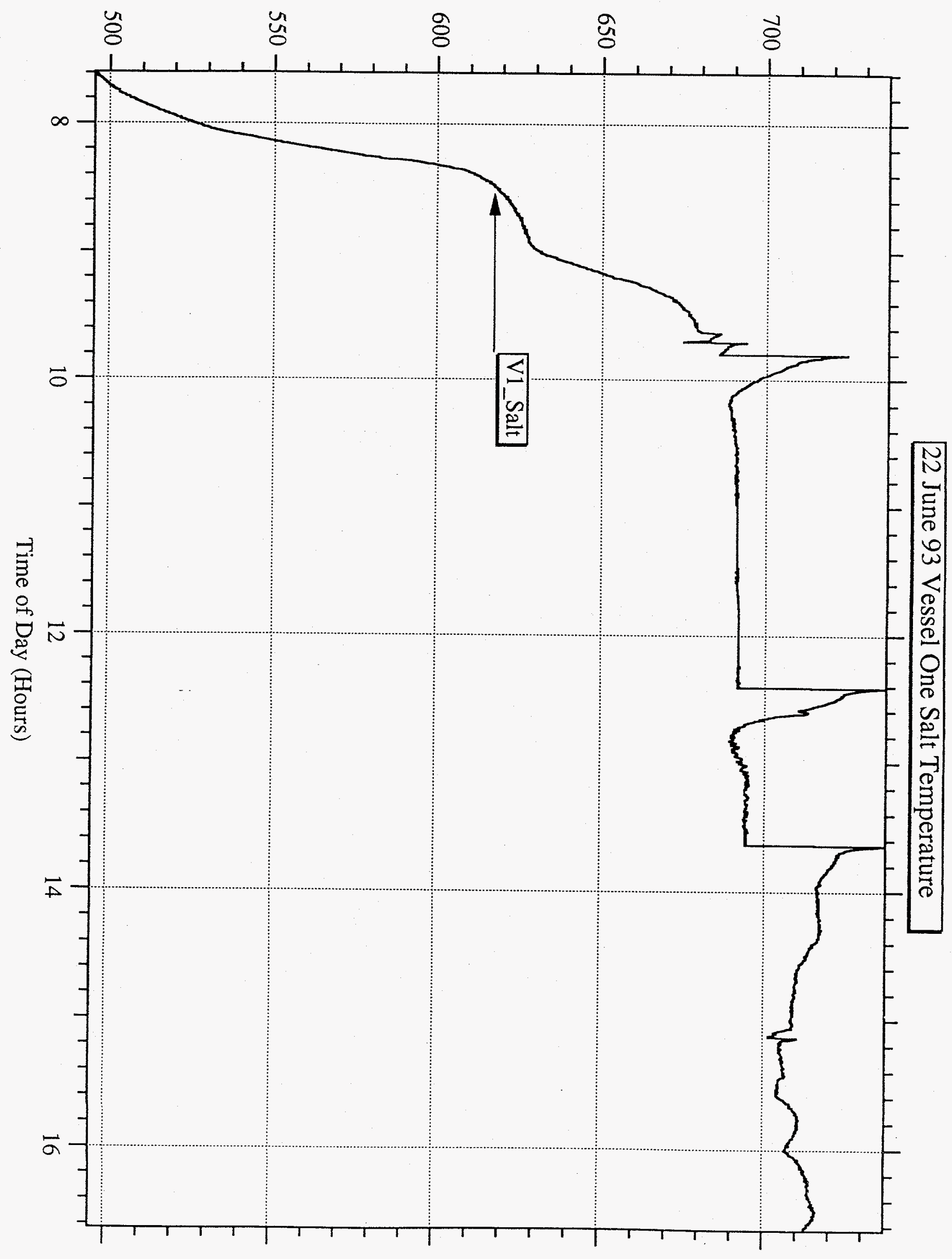




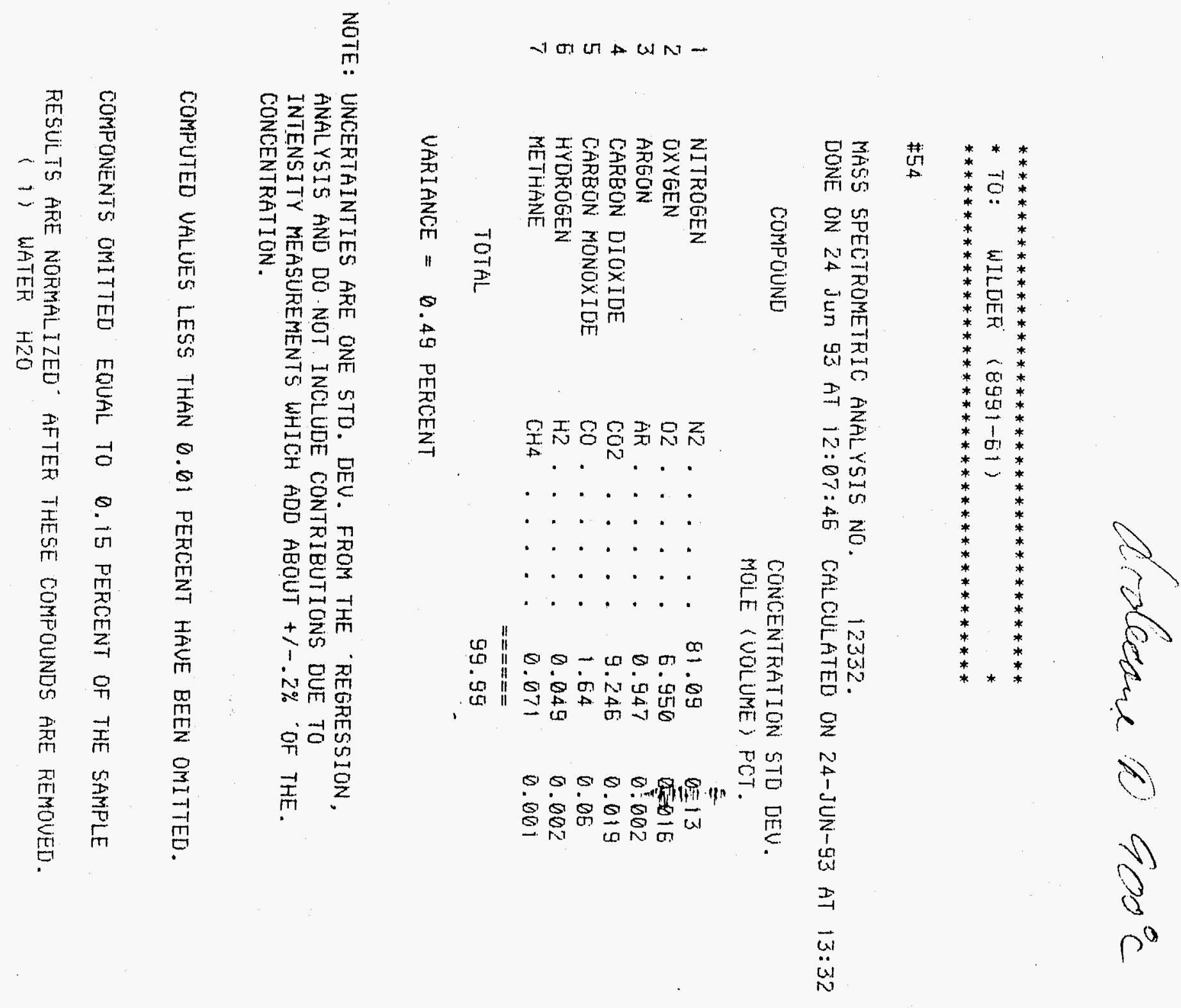




\section{Elhytemstyml@900 $\mathrm{C}$}

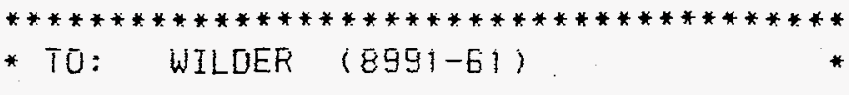

\#4

MASS SPECTROMETRIC ANALYSIS NO. 12329.

UONE ON 24 JUN $5 \overline{3}$ AT $11: 2 \overline{3}: 12$ CALCULATED ON 24-JUN-ȲS AT 13:31

LUMPOUNDE

CONCENTRATION STO DEU. MOLE (VOLUME) FET.

NITROGEN

OXYGEN

ARGON

CARBON DIOXIDE

CARBON MONOXIOE

TOTAL

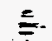

N2.... $79.69 \quad 0=13$

$02 . . . .13 .17 .03$

$A F$. . . 0.9340 .002

$002 . . .5 .501 \quad 0.013$

$\overline{\mathrm{CO}} \cdot . \cdot 0.31 .006$

$=====$

100.00

VARIÁNCE $=0.54$ FERCENT

NOTE: UNCERTAINTIES ARE ONE STO. DEU. FROM THE 'REGRESSION, ANALYSIS AND DO NOT INCLUDE CONTRIBUTIONS DUE TO

INTENSITY MEASUREMENTS WHICH ADO ABOUT +/ -.2\% OF THE. CONEENTRATION.

COMPUTEU VALUES LESS THAN 0.01 PERCENT HAUE BEEN OMITTEO.

COMPONENTS OMITTED EQUAL TO 0.20 PERCENT OF THE SAMPLE

RESULTS ARE NORMALIZED AFTER THESE COMPOUNDS ARE REMOVED.

(i) WATEF HZO 


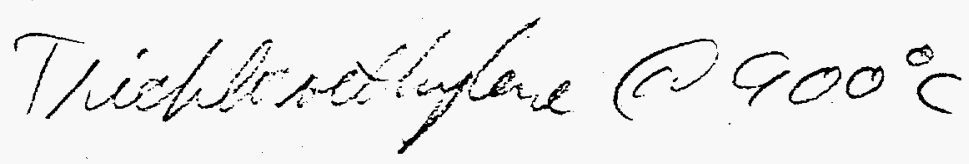

- TO: WILDER (895)-Ei)

$\# 43$

MÁSS SPECTROMETRIC ANALYSIS NO. 12330.

DONE ON 24 JUN 53 AT $11: 38: 04$ CALCULATED ON 24-JUN-53 AT 13:32

COMPOUNŪ

CONCENTRATION STO DEV. MOLE (VOLUME) FCT.

NITROGEN
OXYGEN
ARGON
CAREON DIOXIOE
TOTAL

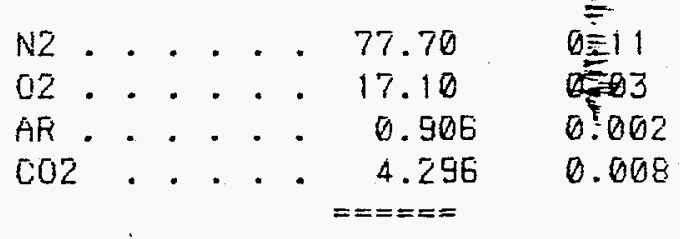

VARIANCE $=0.47$ PERCENT

NOTE: UNCERTAINTIES ARE ONE 5TD. DEU. FROM THE 'REGRESSION, ANALYSIS AND DO NOT INCLUDE CONTRIBUTIONS DUE TO INTENSITY MEASUREMENTS WHICH ADO ABOUT $+1-.2 \%$ OF THE. CONCENTRATION.

COMPUTED UALUES LESS THAN 0.01 PERCENT HAUE BEEN OMITTEO.

COMPONENTS OMITTED EQUAL TO 0.19 PERCENT OF THE SAMFLE

RESULTS ARE NORMALIZEO AFTER THESE COMPOUNOS ARE REMOUEO. ( 1 ) WATER HZO 


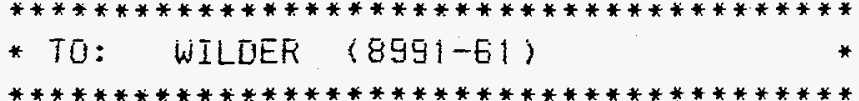

$\# 51$

MASS SPECTROMETRIC ANALYSIS NO. 12331.

DONE ON 24 JUN 93 AT 11:52:56 CALCULATED UN 24-JUN-93 AT 13:32

COMPOUND

CONCENTRATION STU DEU.

MOLE (UOLUME) FCT.

$\begin{array}{ll}1 & \text { NITROGEN } \\ 2 & \text { OXYGEN } \\ 3 & \text { ARGON } \\ 4 & \text { CARBON DIOXIDE } \\ & \\ & \text { TOTAL }\end{array}$

N2.

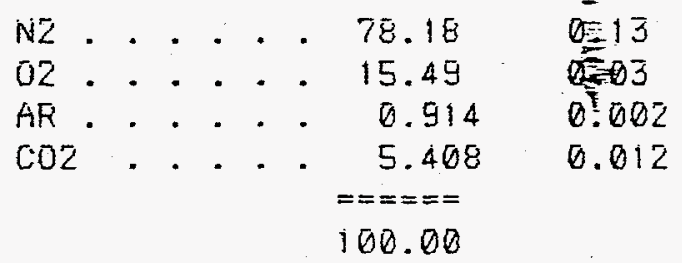

VARIANCE $=0.57$ PERCENT

NOTE: UNCERTAINTIES ARE ONE STO. DEU. FROM THE 'REGRESSION, ANALYSIS AND DO NOT INCLUDE CONTRIBUTIONS DUE TO INTENSITY MEASUREMENTS WHICH ADD ABOUT + $1-.2 \%$ OF THE. CONCENTRATION.

COMPUTED UALUES LESS THAN 0.01 PERCENT HAUE BEEN OMITTEO.

COMPONENTS OMITTED EQUAL TO 0.13 PERCENT OF THE SAMPLE

RESULTS ARE NORMALIZED' AFTER THESE COMPOUNDS ARE REMOVEU.

(1) WATER HZO 
Durrkancens@9oo'

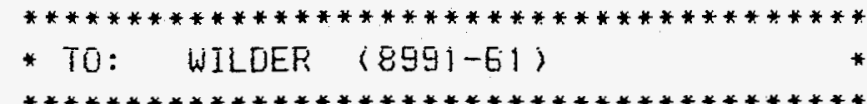

$\# 55$

MASS SFECTROMETRIC ANALYSIS NO. . 12335.

UONE ON 24 JUN 93 AT 12:22:31 CALCULATED ON 24-JUN-933 AT 13:32

COMPOUND

CONCENTRATION STD DEU.

MOLE (VOLUME) PLT.

$\begin{array}{ll}1 & \text { NITROGEN } \\ 2 & \text { OXYGEN } \\ 3 & \text { ARGON } \\ 4 & \text { CARBON DIOXIDE } \\ & \text { TOTAL }\end{array}$

$\mathrm{N2} \cdot \ldots . .78 .53 \quad 017$

$02 . . . \cdot 11.87 \quad 04$

$A R \ldots 0.519 \quad 6.003$

$\mathrm{C02} \cdot \cdots \cdot .280 .02$

UARIANCE $=0.81$ PERCENT

NOTE: UNCERTAINTIES ARE ONE STD. DEU. FROM THE 'REGRESSION, ANALYSIS AND DO NOT INCLUDE CONTRIBUTIONS DUE TO INTENSITY MEASUREMENTS WHICH ADO ABOUT $+1-.2 \%$ OF THE. CONCENTRATION.

COMPUTED UALUES LESS THAN 0.01 PERCENT HÁUE BEEN OMITTED.

COMPONENTS OMITTED EQUAL TO 0.17 PERCENT OF THE SAMPLE

RESULTS ARE NORMALIZED' AFTER THESE COMPOUNUS ARE REMOUED. ( 1 ) WATER HZO 


\section{1- Chboriguatare900}

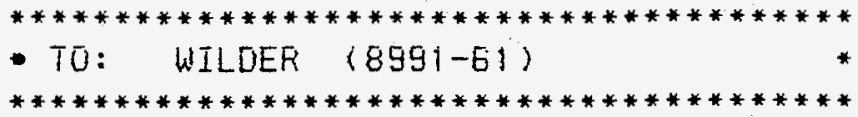

$\$ 56$

MASS SPECTROMETRIC ANALYSIS NO. 12334.

DONE ON 24 JUI 93 AT 13:22:05 CALLCULATED ON 24-JUN-ȲJ AT 14:11

GOMPOUND

CONCENTRATION STD DEV.

MOLE (UOLUME) PCT.

NITROGEN
OXYGEN
AREON
CARBON DIOXIDE
TOTAL

$\mathrm{N2} . . .75 .50$

$02 . . . .14 .19$

$A R+\cdots . .531$

$\mathrm{CO2}$. . . 5.278

$\Xi$

$\begin{array}{ll}1 & \text { NITROGEN } \\ 2 & \text { OXYGEN }\end{array}$

3 AREON

4

$$
\text { TOTAL }
$$$$
100.00
$$

UARIANCE $=0.65$ PERCENT

NOTE: UNCERTAINTIES ARE ONE STD. DEU. FROM THE REGRESSION, ANALYSIS AND DO NOT INCLUDE CONTRIBUTIONS DUE TO

INTENSITY MEASUREMENTS WHICH ADD ABOUT $+1-.2 \%$ OF THE. CONCENTRATION.

COMPUTED UALUES LESS THAN 0.01 PERCENT HAVE BEEN OMITTED.

COMPONENTS OMITTED EQUAL TO "0.0Z PERCENT OF THE SAMPLE

RESULTS ARE NORMALIZED' AFTER THESE COMPOUNOS ARE REMOUED. (1) WATER HZO 

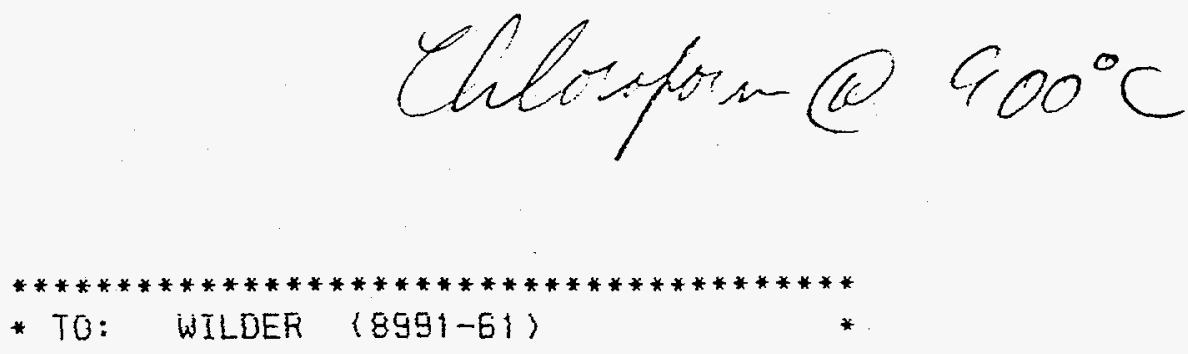

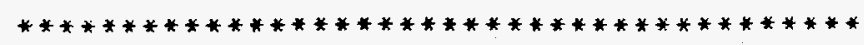

$\# 57$

MASS SPECTROMETRIC ANALYSIS NO. 12335.

DONE ON 24 JUN 93 AT 13:37:D0 CALCULATED ON 24-JUN-93 AT 14:11

COMPOUND

CONCENTRATION STD DEV.

MOLE (UOLUME) PCT.

NITRUGEN
OXYGEN
ARGON
CARBON DIOXIDE
TOTAL

N2 . . . $77.50 \quad 6=13$

$02 . . . .18 .10$. . 02

$A R . \cdots 0.908 \quad 0.002$

$002 \ldots 3.488 \quad 0.008$

TOTAL

100.00

VARIANCE $=0.55$ PERCENT

NOTE: UNCERTAINTIES ARE ONE STD. DEU. FROM THE 'REGRESSION, ANALYSIS AND DO NOT INCLUDE CONTRIBUTIONS DUE TO

INTENSITY MEASUREMENTS WHICH ADO ABOUT $+1-.2 \%$ OF THE. CONCENTRATION.

COMPUTED VALUES LESS THAN 0.01 PERCENT HAVE BEEN OMITTED.

COMFONENTS OMITTED EQUAL TO D. 19 PERCENT OF THE SAMPLE

RESULTS ARE NORMALIZED' AFTER THESE COMFOUNDS ARE REMOUED. (1) WATER HZO 


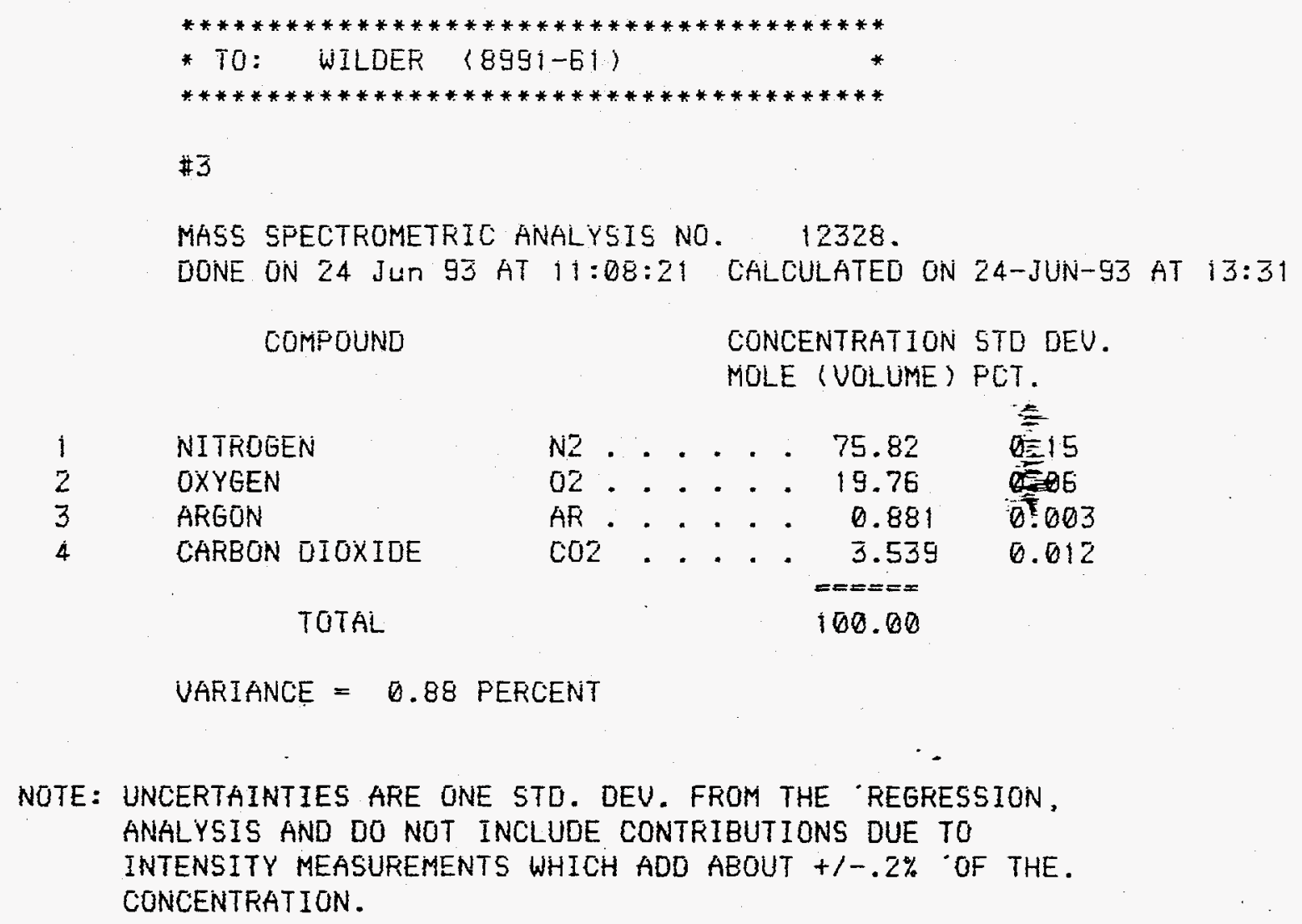

NOTE: UNCERTAINTIES ARE ONE STO. DEU. FROM THE 'REGRESSION, ANALYSIS AND DO NOT INCLUDE CONTRIBUTIONS DUE TO

INTENSITY MEASUREMENTS WHICH ADD ABOUT $+1-.2 \%$ OF THE. CONCENTRATION.

COMPUTEO VALUES LESS THAN 0.01 PERCENT HAVE BEEN OMITTED.

COMPONENTS OMITTED EQUAL TO 0.02 PEFCENT OF THE SAMFLE

RESULTS ARE NORMALIZEO' AFTER THESE COMPOUNDS ARE REMOVEO. (1) WATER H2O 
Two Stage Molten Salt B-241 MSD 2 Sept 93 MSD:DATA:MSD 2 Sept 93

TIMING REFERENCES-- VAX Time =01-SEP-1993 16:26:31.00, Decimal Hours = 16.4419444

9/2/93 12:22:29 PM 12.390444 Start $2.5 \mathrm{scfm}$ of air through system. The air originates through the screw feeder that will deliver about $5.5 \mathrm{gram} / \mathrm{minute}$ of old tyre particals.

$9 / 293$

$9 / 2 / 93$

$12: 23: 27 \mathrm{PM}$

12.406681 Begin rubber (the waste) feed.

$9 / 2 / 93$

$12: 32: 08$ PM

12:51:51 PM

12.551495 Take gas sample \#3.

appears to have stopped.

9/2/93 12:55:55 PM

12.881111 Secure experiment. The flow of rubber

the passage into the injection tube. I will go grab a bite to eat before continuing.

9/2/93

1:50:18 PM 13.857315 Begin injection of rubber with same conditions as

- before.

9/2/93

$9 / 2 / 93$

1:53:30 PM 13.911120

1:57:31 PM 13.978079

Secured, another block.

$9 / 2 / 93$

2:04:07 PM 14.088315

Restart as before.

Secured due to plugging. 


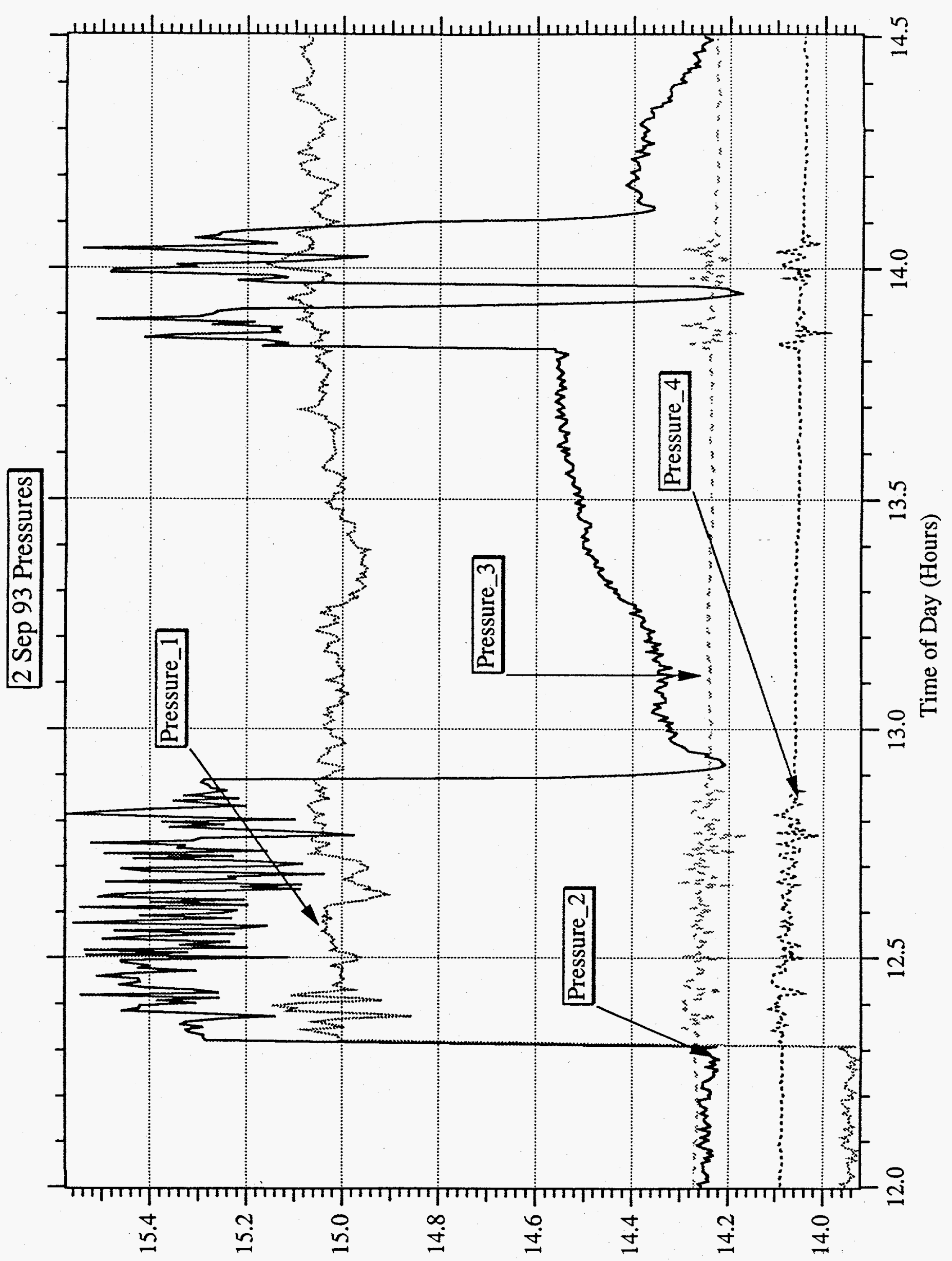




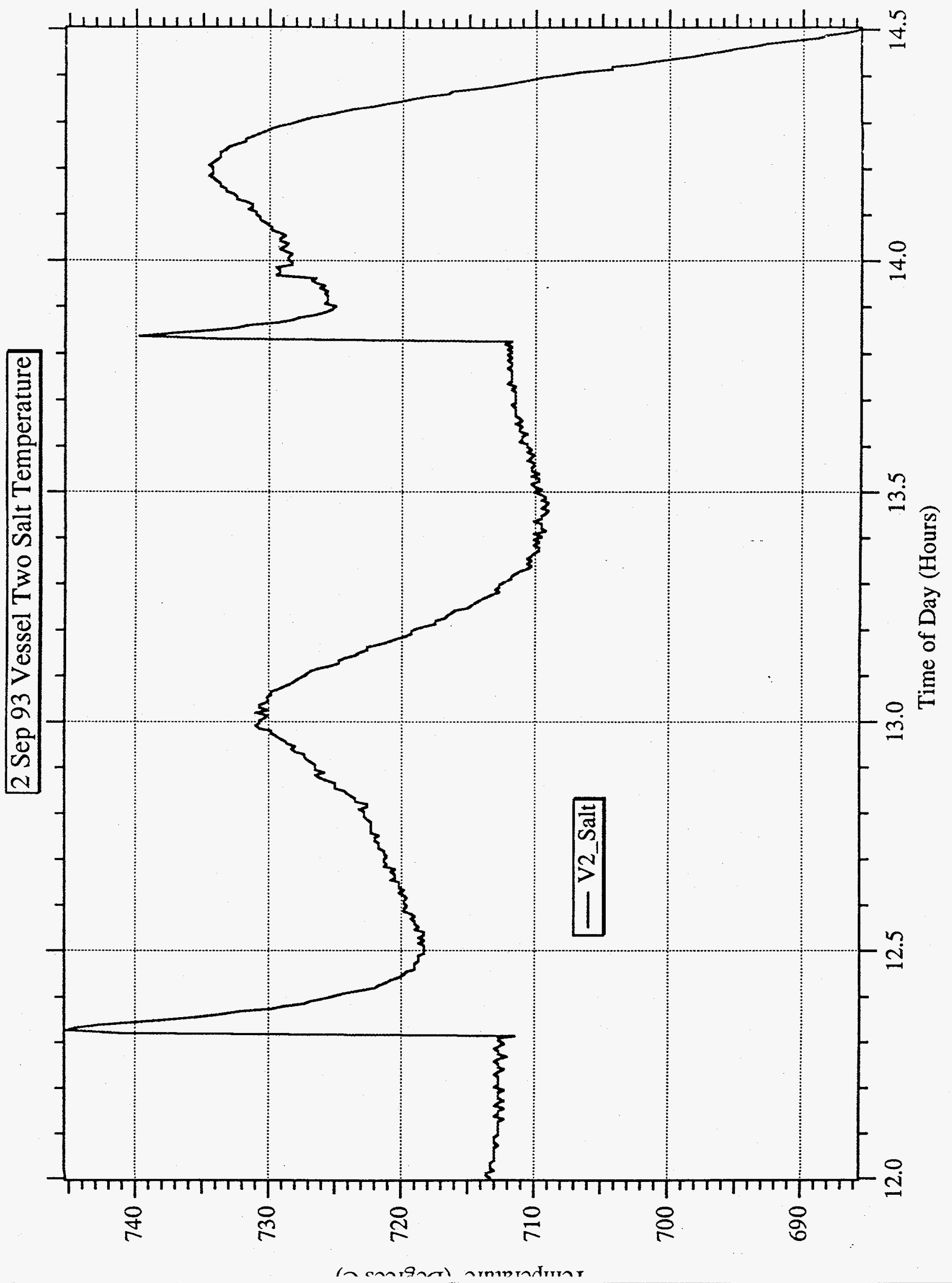




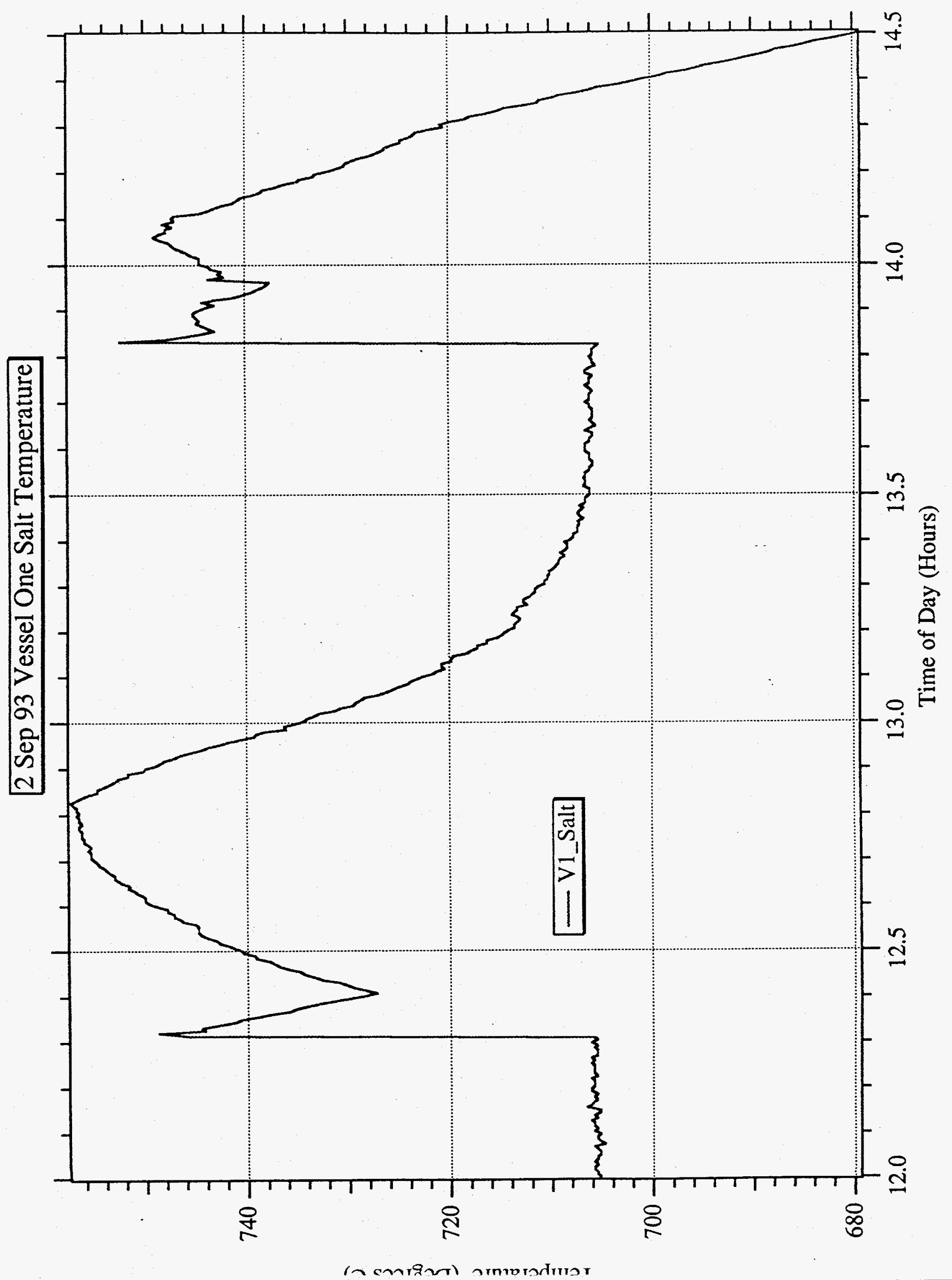




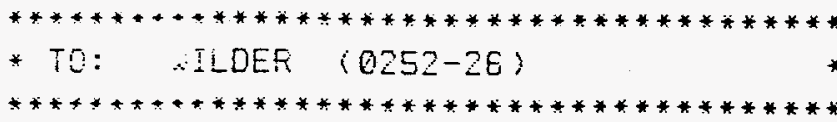

$+3$

MASE EFE-TFOMETRIC ANALYSIS NO. 12510.

BOHE OU ? SEP 93 AT 11:17:44 CALCULATED ON O8-SEF-9E AT 13:52

$50=20100$

CONCENTRATION $5 T D$ DEU.

MOLE (VOLUME) FCT.
NTTEEZE:
$\mathrm{N2} \cdot . . .81 .80$
(3. 17
GYYE?:
AFGOA:
$[2 \cdot . \cdot 10.18$
$0.0 \Xi$
EAFEA: - ZXIE
$A R$. . . . 0.969
B. 2003
$\mathrm{CO} 2$
7.05
0.02
$--\div \div$
$=====$
100.00
UARIANE = O.SE PEFCENT

NOTE: INTERTATRT:EE ARE OME STD. DEU. FROM THE 'REGRESSION, AWALY TE TO DO NOT INCLUOE CONTRIBUTIONS DUE TO

INTENSITY $\because$ ELREMENTS WHICH ADO ABOUT $+i-.2 \%$ OF THE.

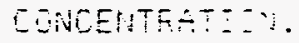

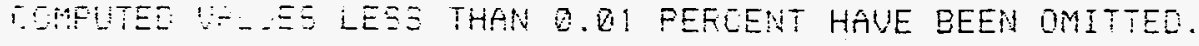

OMFOHENE : ITTED EQUAL TO 0.34 FEFCENT OF THE SAMPLE

FEZULTE GFE MFMALZES AFTEF THESE COMPOUNDS ARE FEMOVES. (1) $\therefore$ YTEF H2O 
Two Stage Molten Salt B-241 MSD 3 Sept 93 MSD:DATA:MSD 3 Sept 93 TIMING REFERENCES--VAX Time = 02-SEP-1993 14:41:40.00, Decimal Hours = 14.6944444

9/3/93 11:29:17 AM 11.501426 This is the continuation of the experiment begun yesterday. All of the rubber has been removed and sieved so as to prevent clogging of the combustion gas line at the screw feed injector. The purpose of this experiment is to demonstrate a long duration reliably controlled destruction of the used tyres!

9/3/93 11:34:00 AM 11.580292 Experimental conditions: $2.5 \mathrm{scfm}$ combustion air and the feed speed of the screw feed apparatus set to maximum. This setting is about $5.6 \mathrm{~g} / \mathrm{min}$ of chopped tyres. This value will be confirmed later.

- $9 / 3 / 93$

9/3/93

$11: 34: 31$ AM

11.588819 Begin feed.

11:45:36 AM

11.773866

12:07:10 PM

11.773866 Take gas sample \#54.

- $9 / 3 / 93$

$9 / 3 / 93$

1:14:31 PM

12.134190 Take gas sample \#56.

Take gas sample \#55.

9/3/93 1:16:04 PM 13.285468 This experiment has been in continuous steady-state operation since it began about 11:30. Everything is very stable and quiet and I'm becoming bored with it!

9/3/93 to $700^{\circ} \mathrm{C}$.

9/3/93 gas sample \#51.

1:43:05 PM 13.736940 Secure heater on first stage to reduce temperature

9/3/93 4:06:21 PM 16.130560 The whole experiment has proceeded flawlessly.

Take the final exhaust gas sample, gas sample \#57.

9/3/93 4:27:25 PM 16.482477 Salt temperature began to decline. I suspect we are out of rubber. Shut down experiment.

9/3/93 4:35:00 PM 16.609287 Hopper is not empty, though most of the rubber is gone. I was interpreting noise a bit too enthusiastically. 


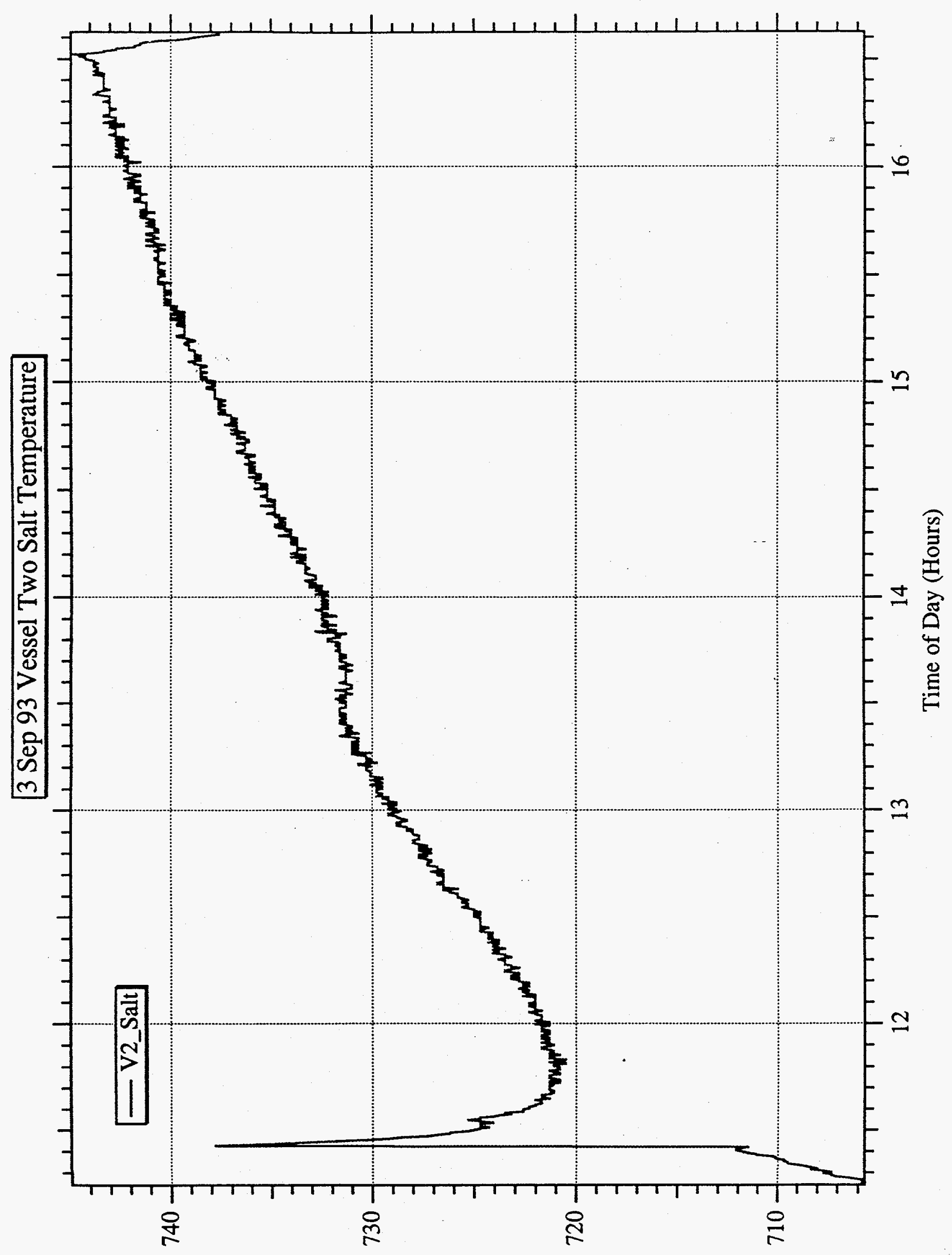




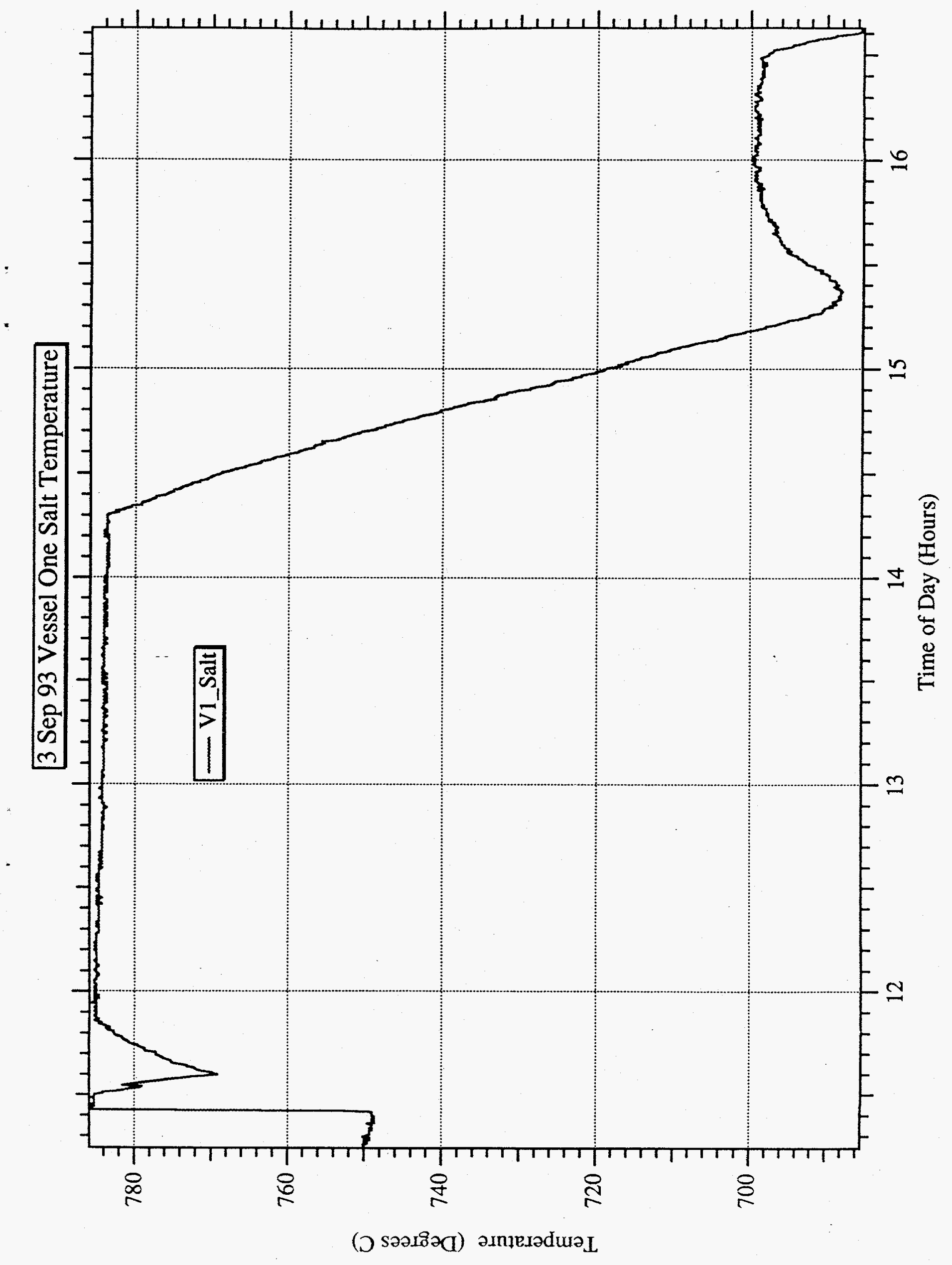




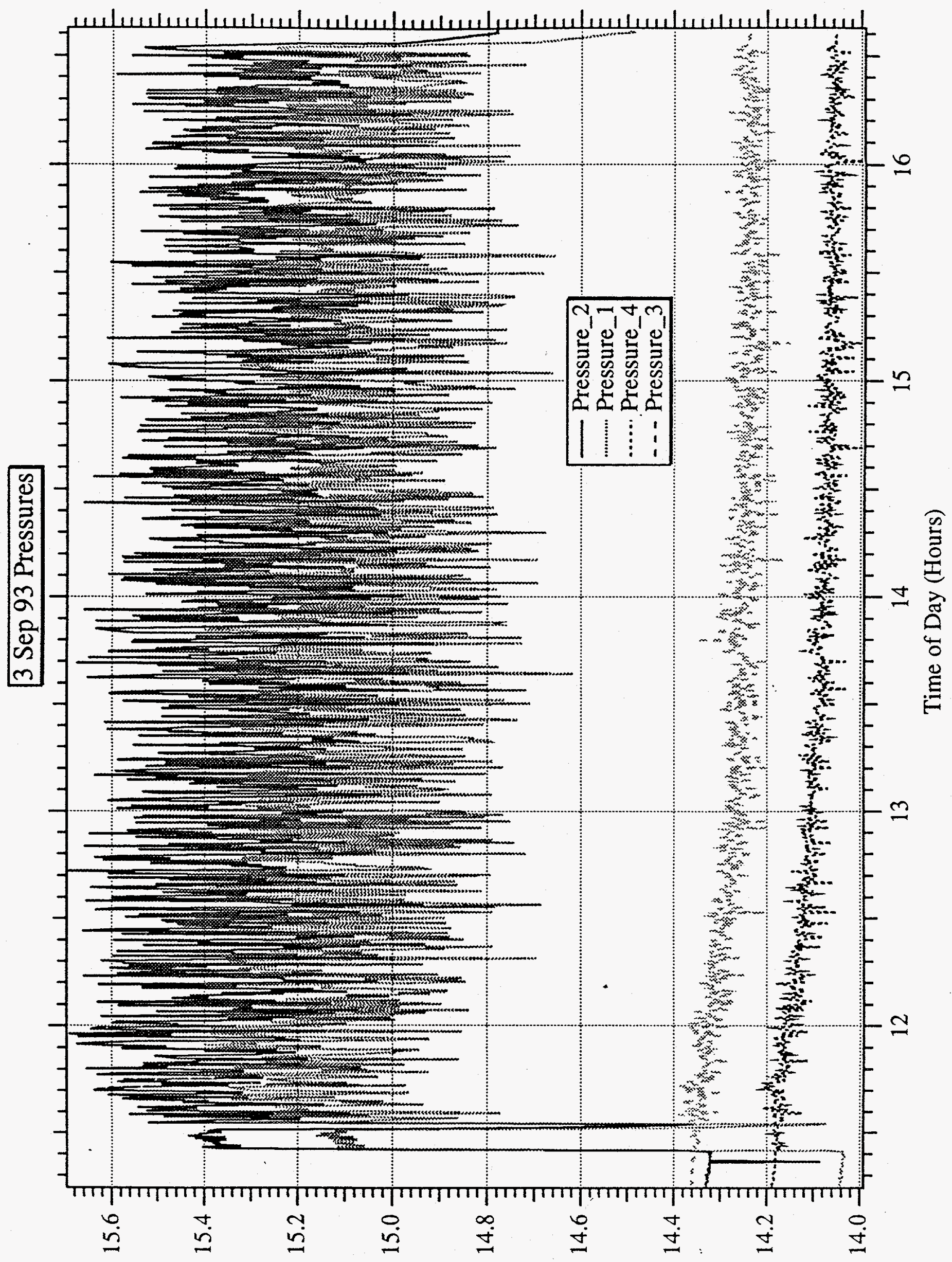

(VISd) arnssard 


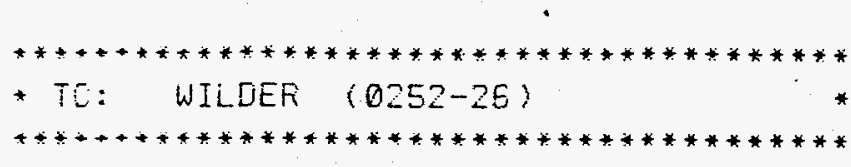

$+54$

MAES ZFESTROMETRIC ANALYSIS NO. 12511.

DUIE 7 SEP 93 AT 11:33:59 CALCULATED ON D8-SEP-93 AT $13: 53$

-MPบUNบ

CONCENTRATION STE DEU.

MOLE : VOLUME) FCT.

\begin{tabular}{|c|c|}
\hline 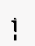 & $\frac{1 \bar{i}}{\bar{i}} \bar{F}=\bar{l}$ \\
\hline 2 & $-\therefore: \Sigma \equiv$ \\
\hline 3 & $\triangle E E \because$ \\
\hline 4 & OFEZ, OIXIOE \\
\hline ᄃ & ZFEE \\
\hline
\end{tabular}

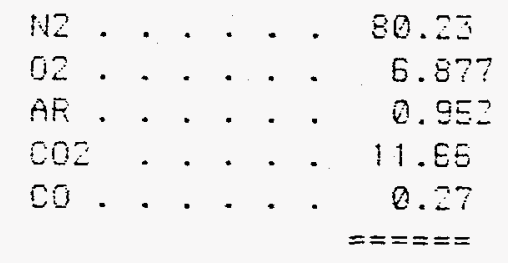

0.15

100.00

RTFE-EE = D.EE PEREENT

DOTE: UHETT:TES AFE ONE STO. DEU. FROM THE REEFESSTON,

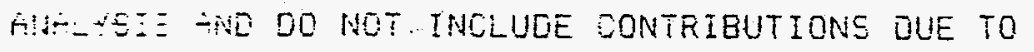
TH:ESE YEASUFEHENTS WHICH ADD ABOUT $+i-.2 \%$ OF THE. -

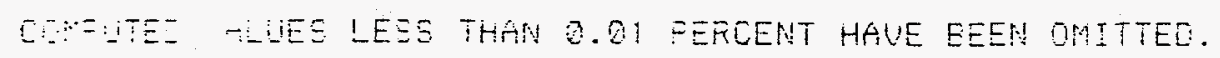

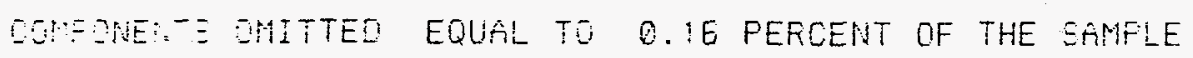

FEE:UTE WATER HZO 


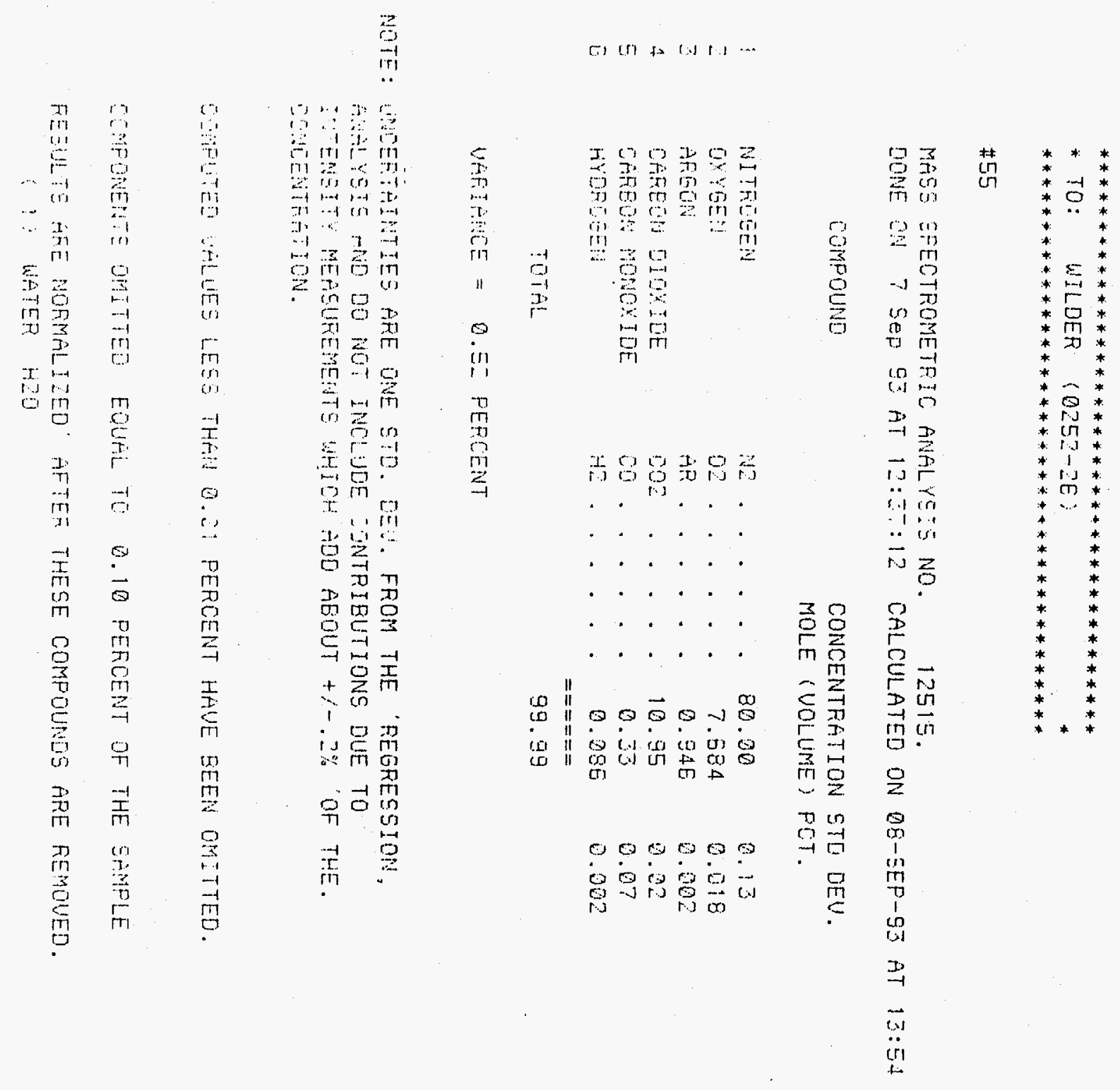




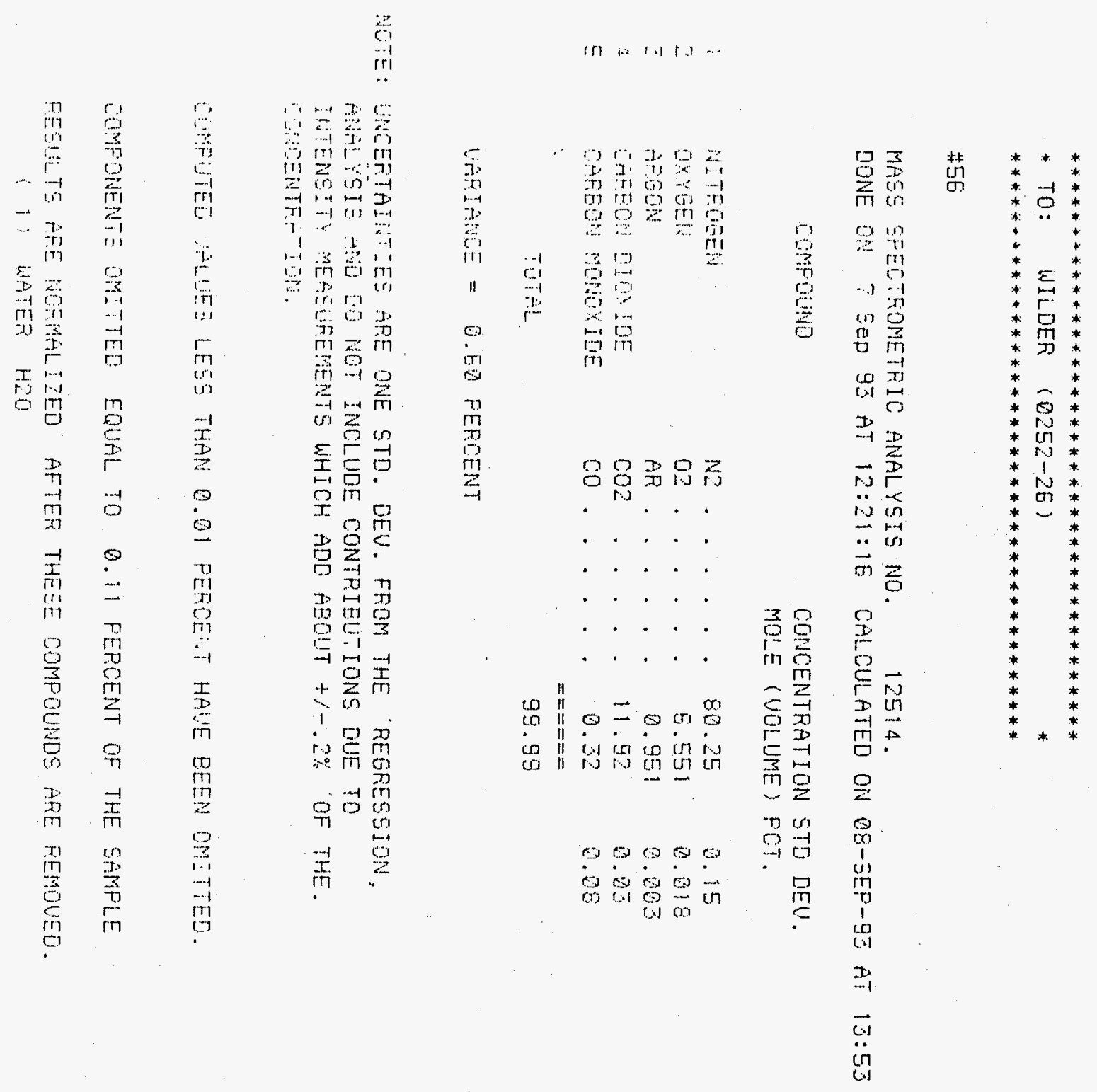




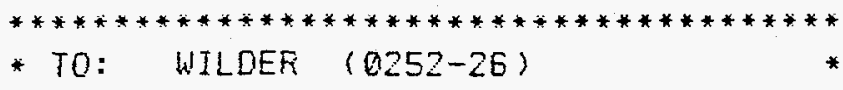

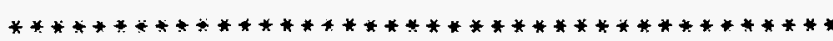

$\# 57$

MAES SFECTROMETRIC ANALYSIS NO. 12513.

DONE UN, 7 SEP 93 AT 12:05:23 CALCULATED ON 08-5EP-93 AT 13:E3

COMFOUNO

CONCENTRATION STD DEU.

MOLE IVOLUME: PCT.

$\begin{array}{ll}\because & \text { NITEOEEN } \\ \vdots & \text { OXYEEN } \\ \vdots & \text { AFGON } \\ \div & \text { CAREON DIOXIDE } \\ \equiv & \text { CAFEON MONOXIOE }\end{array}$

TOTAL

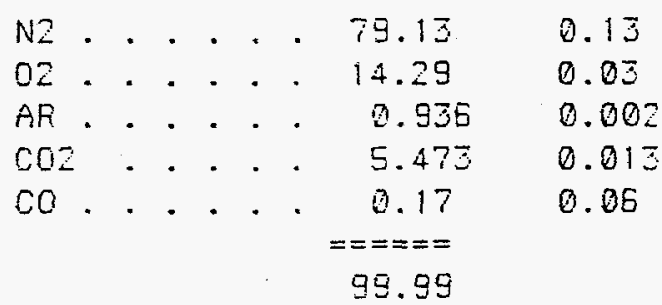

VARIANEE = 0.60 PEFCENT

WOTE: LNCERTAINTIES ARE ONE STO. DEU. FROM THE REGRESSTON, ANAL YSIE AND DO NOT INCLUDE CONTRIGUTIONE DUE TO

INTENSITY MEASUREMENTS WHIEH ADD ABOUT $+1-.2 \%$ OF THE. COMCEMTEATION.

COMFUTED UAUES LESS THAN O.DI PEFCEMT HAVE EEEN OMITTEO.

COMFONENTE OMITIED EQUAL TO 0.11 FERCENT OF THE SAMFLE

FESULTS ARE NORMALIZED AFTEF THESE COMPOUNDS ARE FEMOUED.

(1) WATEF H2O 
Two Stage Molten Salt B-241 17 Sep 93 Run MSD:DATA:17 Sep 93 Run TIMING REFERENCES-- VAX Time = 16-SEP-1993 18:42:02.00, Decimal Hours $=$ 18.7005556

9/16/93 6:45:57 PM 18.765926 Set timer to start heaters at 0500 hours, 17 Sep 93. I hope I got it right.

9/17/93 10:17:42 AM 10.307847 This run to operate at 90\% stoicheometric. This is to test the tar buildup hypothesis. Combustion flow will be set at $1.8 \mathrm{scfm}$ and the rubber flow is 4.7 gram per minute. I will now wait for the second stage to reach temperature $\left(900^{\circ}+\mathrm{C}\right)$ since this test is to examine the tar buildup phenomenon. 9/17/93 10:19:51 AM 10.343565 Combustion air feed begun. Start rubber feed.

9/17/93 10:26:42 AM

9/17/93 10:31:13 AM

9/17/93 10:35:54 AM

9/17/93 11:52:03 AM

10.458380 Rubber feed plugged. Stopped momentarily. 10.533671 Rubber bridged. Clear and restart.

10.612023 Rubber stopped again!! 11.884236 Suspect pyrolized rubber is clogging up the injection tube and/or the diffusion plate of the first vessel. Raised the temperature to $830^{\circ}$ $\mathrm{C}$ and purged through air only to burn out the char. I've no idea how clogged the exhaust riser is. It is too hot to disassemble now. Will restart run using $120 \%$ combustion air and the high temperature. The plan is to let the temperature creep down to $700^{\circ} \mathrm{C}$.

9/17/93 11:54:55 AM 11.932315 Start rubber feed. Combustion air flow is 2.4 scfm. Rubber feed is believed to be $4.7 \mathrm{gram}$ per minute.

9/17/93 12:07:41 PM $\quad 12.145634$ Take gas sample "A".

9/17/93 12:29:14 PM $\quad 12.505560$ Injection plugged. Secure feed.

9/17/93 12:58:39 PM 12.996880 Shut down all power to heaters and secure combustion air. Exhaust riser appears to be plugged. 


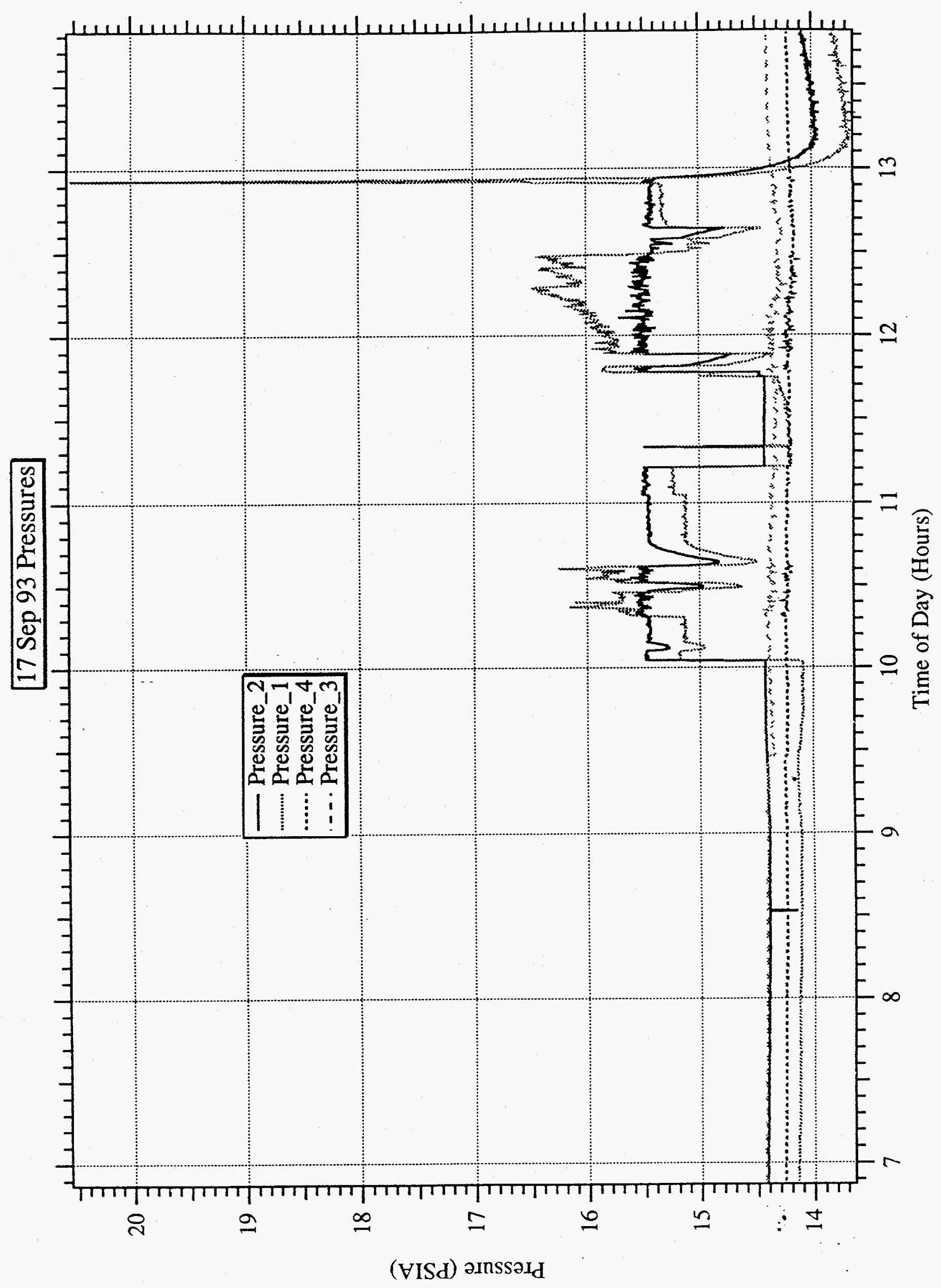




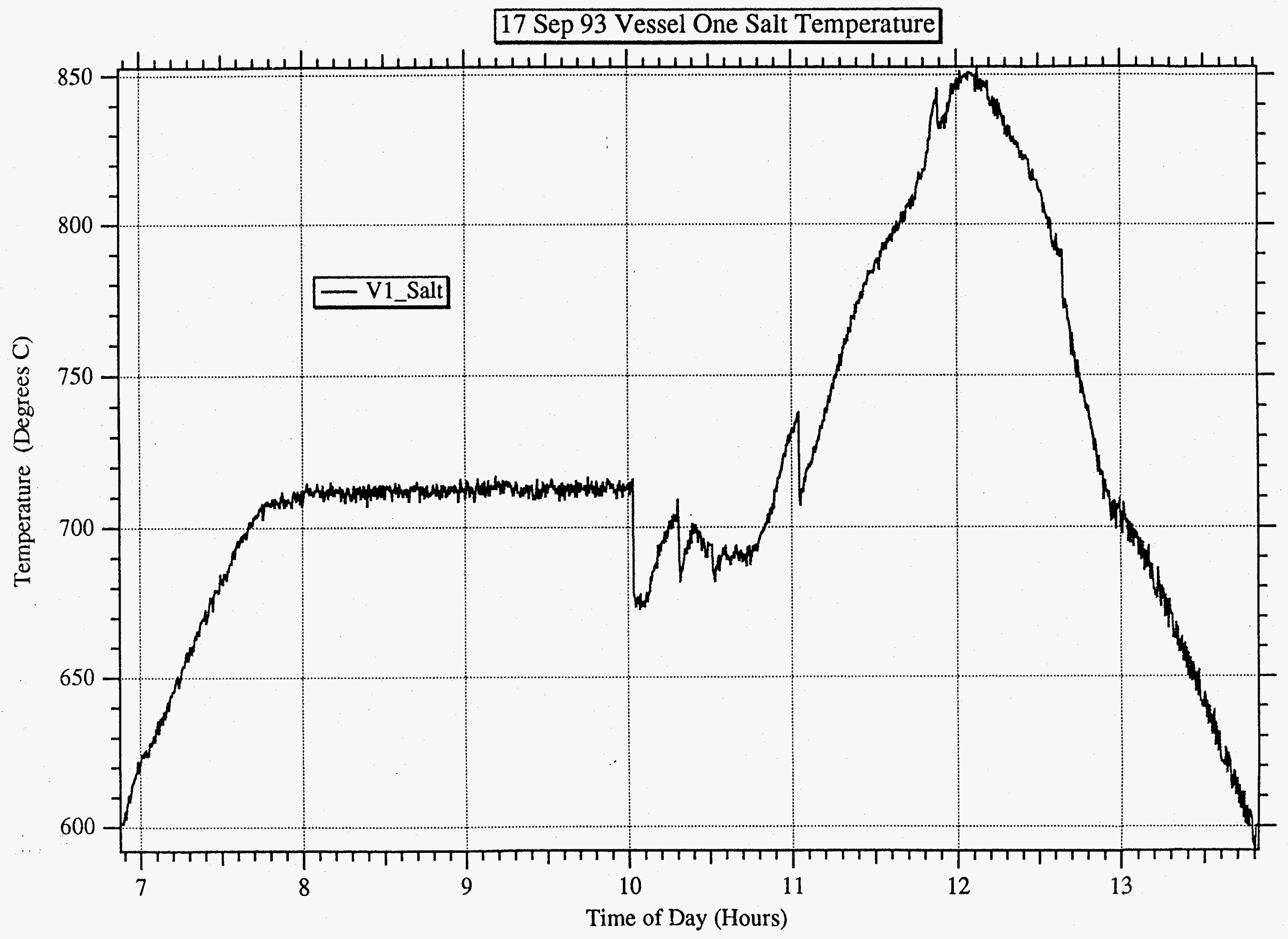




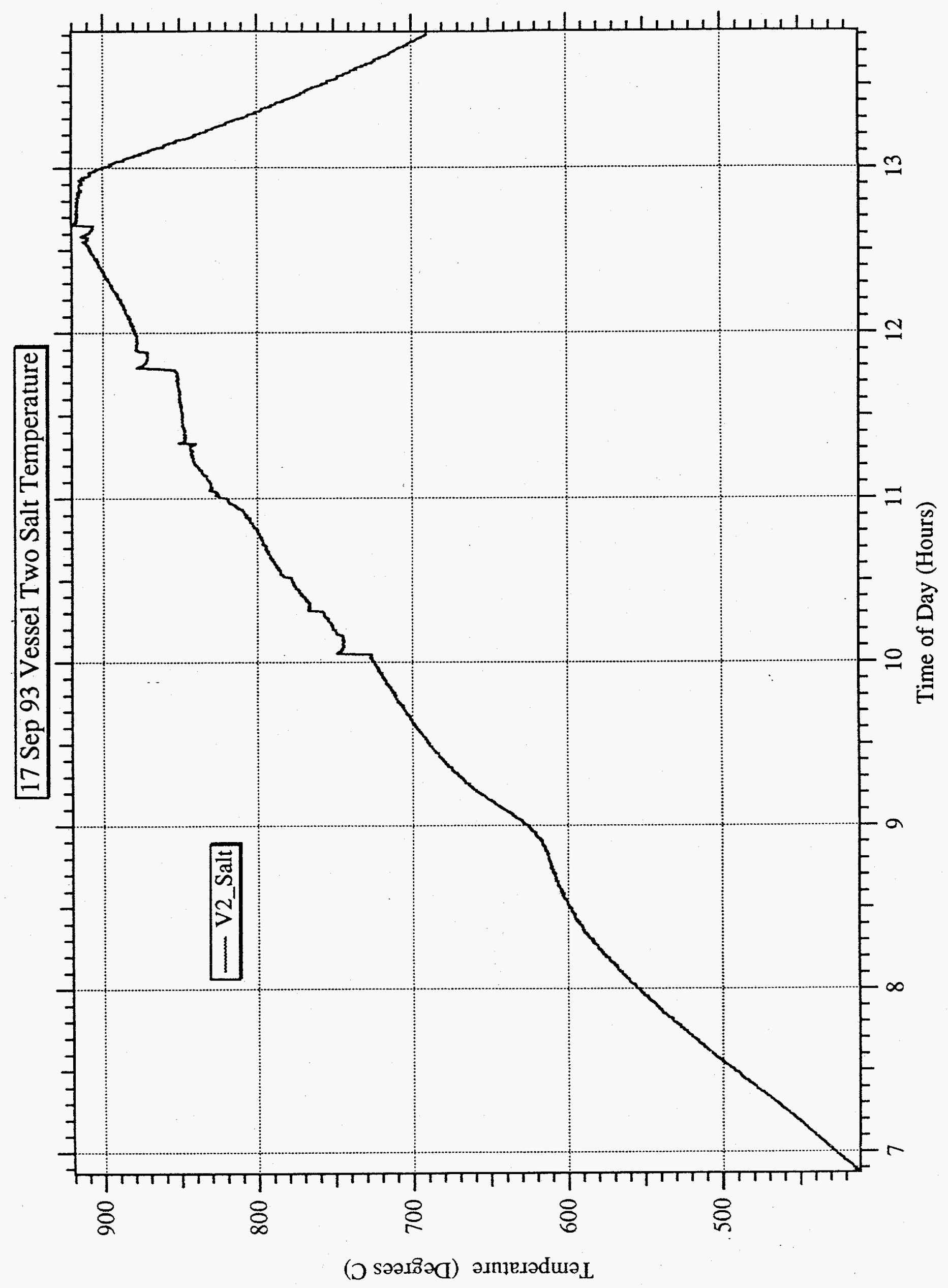




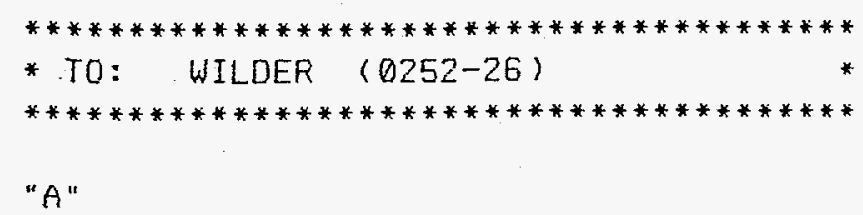

MASS SPECTROMETRIC ANALYSIS NO. 12542.

DONE ON 22 sep 93 AT $09: 31: 51$ CALCULATED ON 22-5EP-93 AT 11:22

COMPOUND

CONCENTRATION STD DEV. MOLE (VOLUME) PCT.

NITROGEN
OXYGEN
ARGON
CARBON DIOXIDE
CARBON MONOXIDE
NITROUS OXIDE

TOTAL

\begin{tabular}{|c|c|c|c|c|c|}
\hline N2 & . & * & * & 79.21 & 0.07 \\
\hline 02 & . & . & . & 4.978 & 0.006 \\
\hline$A R$ & • & . & * & 0.939 & 0.001 \\
\hline $\mathrm{CO} 2$ & . &. & . & 14.177 & 0.014 \\
\hline $\mathrm{CO}$. & - & • & • & 0.65 & 0.04 \\
\hline$N 20$ & . & - . & . & 0.044 & 0.006 \\
\hline
\end{tabular}

100.00

UARIANCE $=0.29$ PERCENT

NOTE: UNCERTAINTIES ARE ONE STD. DEU. FROM THE 'REGRESSION, ANALYSIS AND DO NOT INCLUDE CONTRIBUTIONS DUE TO INTENSITY MEASUREMENTS WHICH ADD ABOUT $+1-.2 \%$ 'OF THE. CONCENTRATION.

COMPUTED VALUES LESS THAN 0.01 PERCENT HAVE BEEN OMITTED.

COMPONENTS OMITTED EQUAL TO 0.02 PERCENT OF THE SAMPLE RESULTS ARE NORMALIZED' AFTER THESE COMPOUNDS ARE REMOVEO. (1) WATER H2O 
9/20/93 1:56:55 PM 13.956894 Restarted this experiment this morning. This program is up to its usual reliability. I am perpetually looking at the "Restart CAMAC", etc. and have no idea as to how to get rid of it. Anyway, the plan is to inject $3 \mathrm{~g} / \mathrm{min}$ of rubber and $120 \%$ of stoicheometric air. This is $1.5 \mathrm{scfm}$ (approximately).

9/20/93 2:07:08 PM 14.127551 This is a demonstration for Kelly and Bruce.

9/20/93 2:13:21 PM 14.231222 Begin injection of rubber.

9/20/93 2:25:53 PM 14.440722 we had to turn the system off for a couple of minutes but now were back on line

9/20/93 3:23:23 PM 15.401315 Installed a pneumatic vibrator on the rubber feed to, hopefully, stop the periodic plugging that has been plaguing us today. It seems to work, but the noise may drive us all mad.

9/20/93 3:57:11 PM 15.965968 Feed clogged, and unclogged, again.

9/20/93 4:10:38 PM 16.190935 Rubber feed bridged again, and was unclogged.

Vibrator quit working. Its demise is not a completely unwelcomed event.

9/20/93 4:33:12 PM 16.567551 Take gas sample "B"

9/20/93 4:44:49 PM 16.762083 this is a test 
Two Stage Molten Salt B-241 20 Sep 93 Run Cont. MSD:DATA:20 Sep 93 Run Cont.

TIMING REFERENCES-- VAX Time = 20-SEP-1993 19:44:24.00, Decimal Hours = 19.7400000

9/20/93 7:50:02 PM 19.834208 This is a continuation of 20 Sep 93 Run. The computer inexplicably locked and was restarted. It inexplicably locked again. It was restarted again. This is that time.

Corrie!!!!

$9 / 20 / 93$

7:50:33 PM 19.842694 The time is now about 1950 hours, 20 Sep 93.

9/20/93

7:53:35 PM 19.893056

Take gas sample " $\mathrm{C}$ ".

9/20/93 8:35:52 PM 20.599917 pop valve on hopper opened, line was clo gged with large parts of rubber. allso I turned the

salt up one degree (733 from 732).

$\mathrm{BB}$

9/20/93 10:32:12 PM

22.543444 Stopped feed, opened hopper, and added five (5) bottles of rubber crumbs. The bottles are emptied $500 \mathrm{~g}$. sodium carbonate jars. 9/20/93 10:33:00 PM 22.556662 This is the first refill of the hopper since startup. Time was 2230 hours.

9/20/93 10:57:40 PM 22.969000 Take gas sample "D".

9/20/93 11:03:21 PM 23.064019

9/20/93 11:04:01 PM 23.075144

9/21/93 12:16:58 AM $\quad 24.293977$ note! with heater set at 734 degrees $\mathrm{c}$, the salt temp. should remain at 700-699 degrees; however if a clog happens to the feed then the temp. will take a sudden drop to about 395 degrees.

9/21/93 12:39:10 AM 24.664866

9/21/93 1:19:29 AM 25.338444 for the last ten minutes or so the feed has been clogging more than in the past. Almost as if the feed material is alittle damp.

9/21/93 2:31:05 AM 26.534741 we lost feed for a couple of minutes; the line (poly flow) became plugged.

9/21/93 2:57:31 AM 26.976259 pulling vial sample "E".

9/21/93 3:23:20 AM 27.407671 checking level of feed material in hopper.

9/21/93 3 3:28:04 AM 27.486356 added four jars of feed material to hopper.

9/21/93 4:35:22 AM 28.611218 having problems with the feeder again

9/21/93 6:42:14 AM 30.730727 we'll be taking sample " $F$ " at 6:50

9/21/93 11:40:29 AM 35.713968 Take gas sample "G".

9/21/93 12:23:28 PM 36.431926 Shutdown feed for a short time to replace

$1 / 4$ inch injection tube with $3 / 8$ inch tube.

9/21/93 12:27:22 PM $\quad 36.497264$ Restart injector with 3/8 tube.

9/21/93 12:46:23 PM 36.814833 Stop feed to refill hopper.

9/21/93 12:47:45 PM 36.837593 Restart without adding additional rubber.

9/21/93 12:53:42 PM 36.936727 Note: For the last feed stoppage, I tumed off the screw feed and opened the hopper without shutting down the combustion air or disconnecting the injection tubing. The vessel pressure log does not show the

characteristic drop in pressure. I surmise that this indicates that the rubber entrained in the screw feed acts as a sufficient seal so as to maintain the pressure.

9/21/93 3:56:40 PM 39.993903 Take gas sample "H". 
9/21/93 3:57:30 PM 40.007940 System has performed flawlessly for hours. I hope I'm not speaking prematurely.

9/21/93 4:03:54 PM 40.114741 Stop rubber feed to refill the hopper.

9/21/93 4:05:52 PM 40.147366 Restart rubber feed after adding two bottles of rubber crumbs.

9/21/93 7:50:38 PM 43.902940 droped temp. down to 723 for awhile trying to get closer to $700 \mathrm{c}$ on salt temp. result was to low. so I turned it up to $725 \mathrm{c}$ until temp returned. Then I will put setting back to $724 \mathrm{c}$ where it seems to run best.

B.B.

9/21/93 8:00:32 PM 44.068310 Removed sample "I". B.B.

9/21/93 10:15:13 PM 46.318843 At approx. 10:05 there was a pressure rise and I shut down air \& rubber feed.

B.B.

9/21/93 10:27:02 PM 46.516111 This piece of crap software (Corrie!!) went ape and declared all pressures to be 1000 psi. The apparatus was shut down for awhile. The CAMAC crate was shutdown and restarted and this file continued but now we watch Corrie's "Restart CAMAC ..." because it won't go away.

9/21/93 10:42:09 PM 46.768648 All pressure readings now say zero. I will reboot this computer and continue on a follow on file. File Name will be 20 Sep 93 (2) 9/21/93 10:44:22 PM 46.805731 Change my mind. Follow on file will be called 20 Sep $93 a$ 


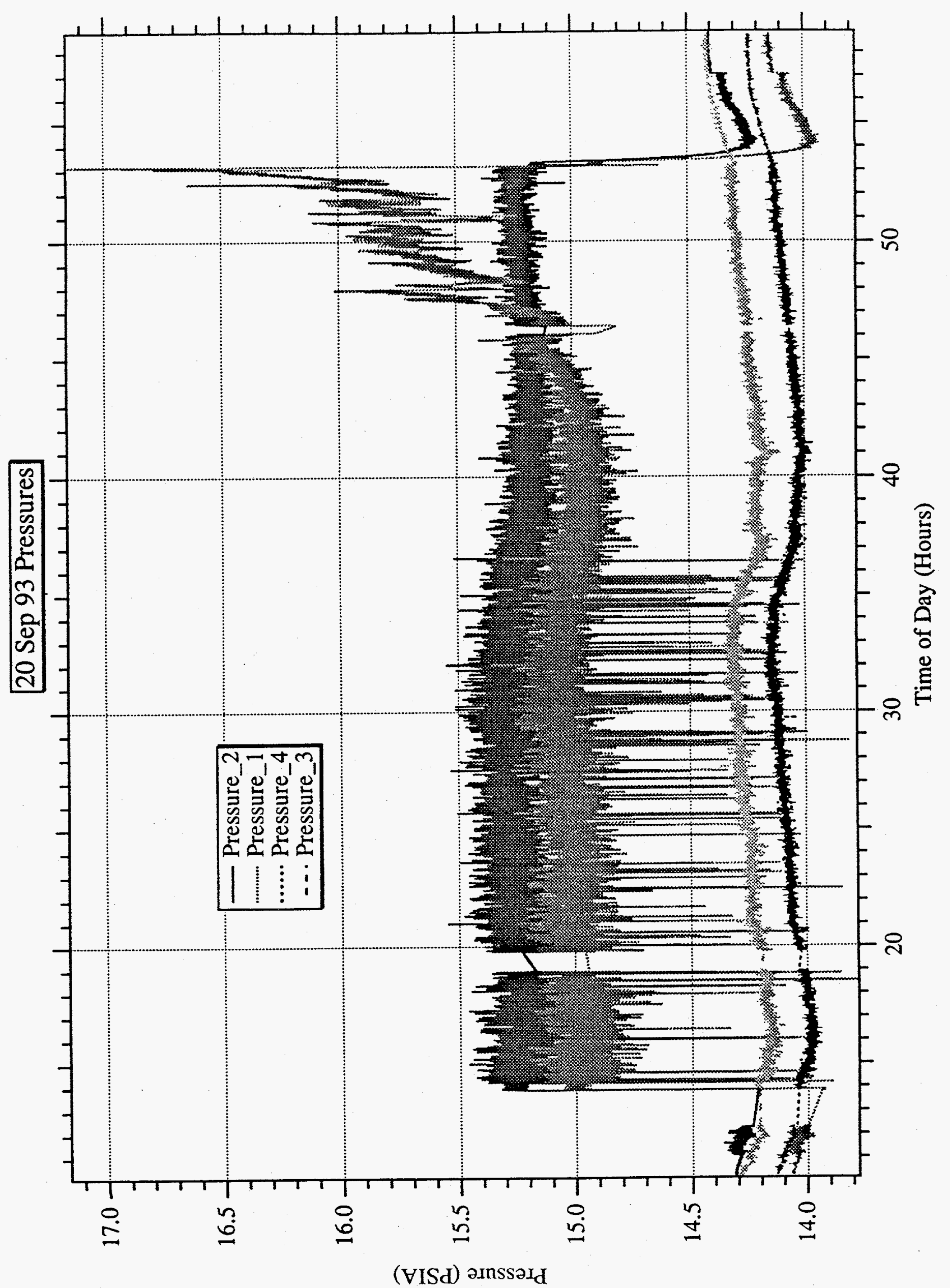


1 emperarure (1)grees 4 )

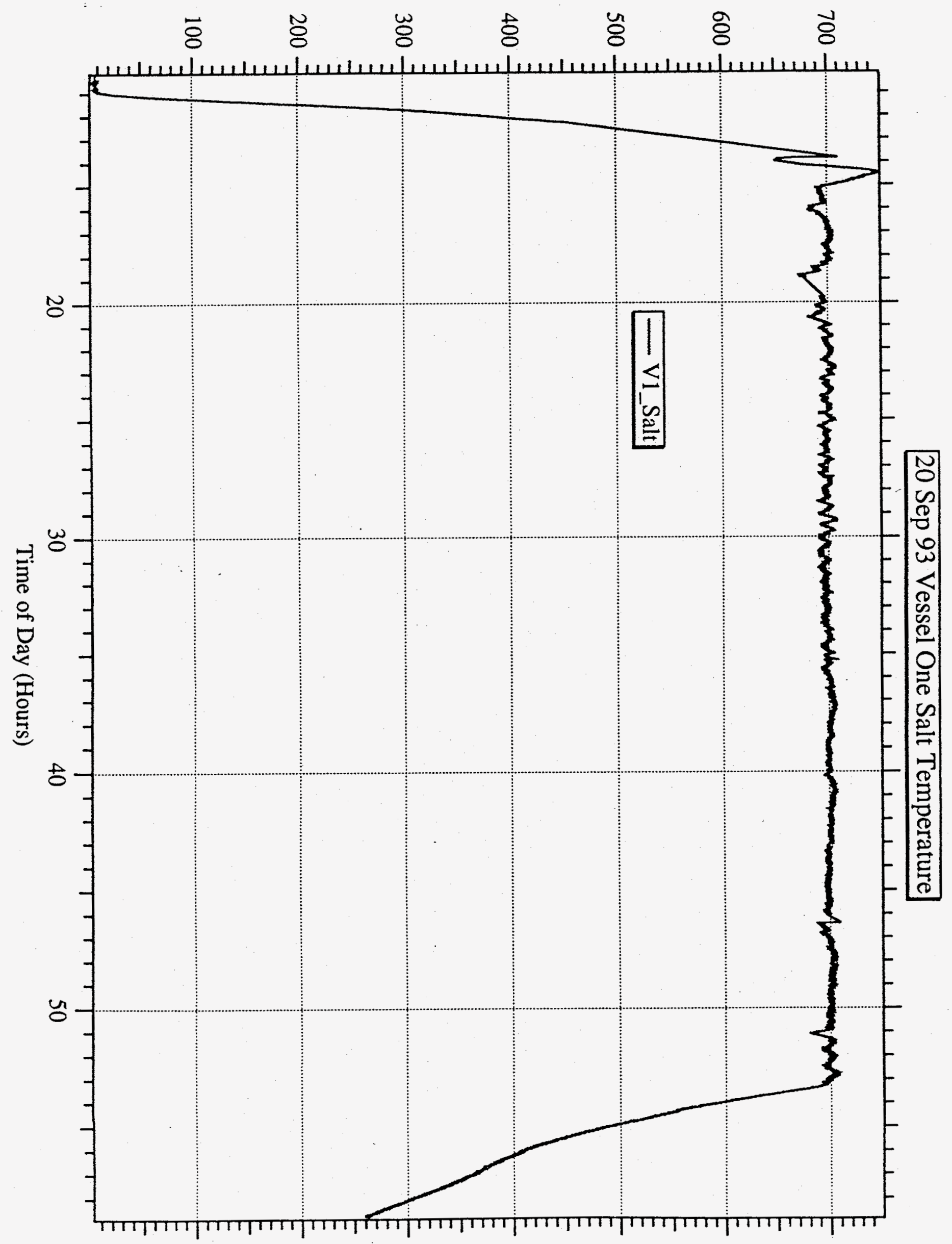




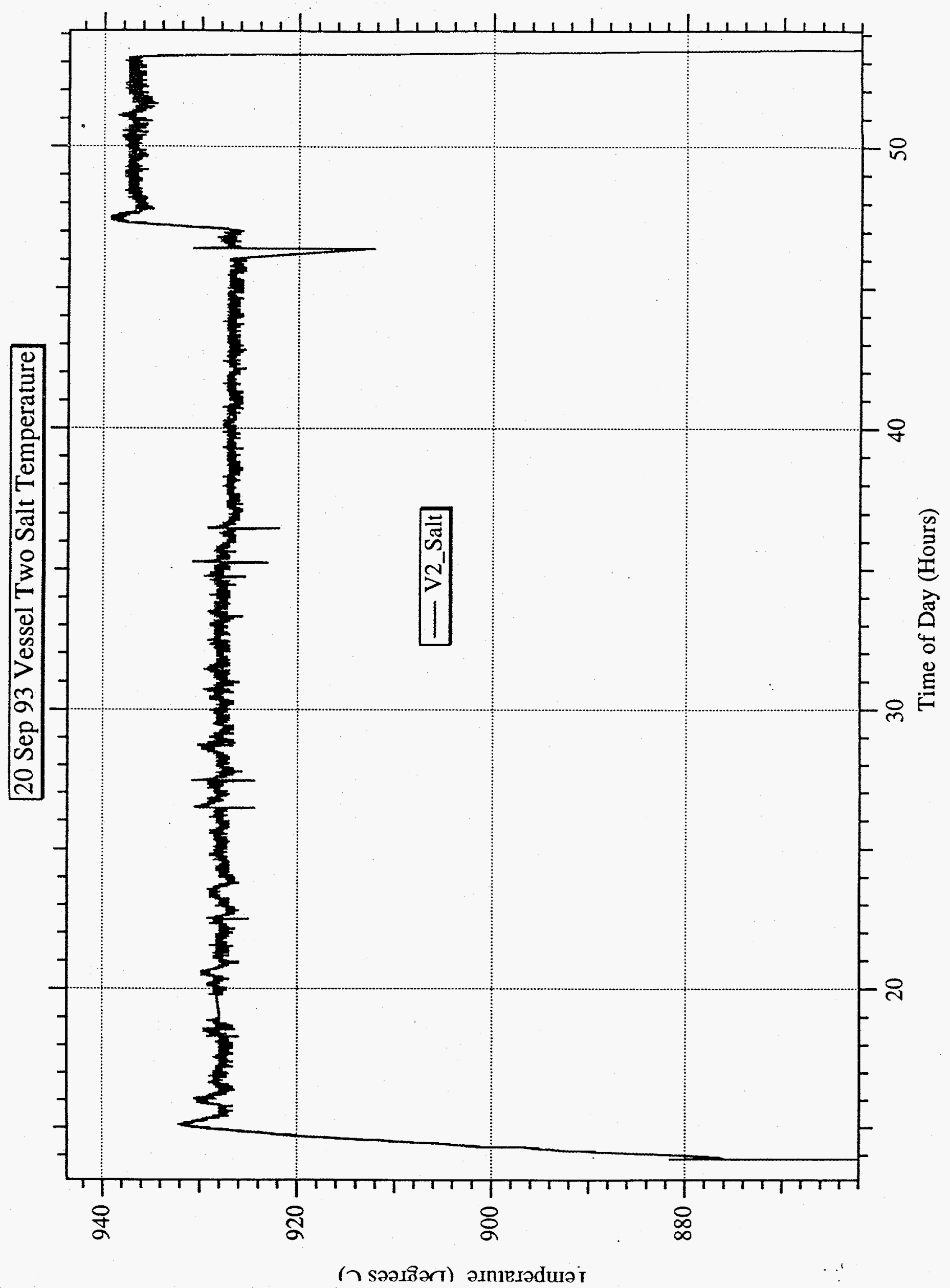




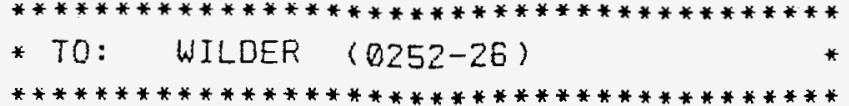

"A"

MASS SPECTROMETRIC ANALYSIS NO. 12542.

DONE ON 22 sep 93 AT 09:31:51 CALCULATED ON 22-5EP-93 AT 11:22

COMPOUND

CONCENTRATION STD DEV. MOLE (VOLUME) PCT.

NITROGEN
OXYGEN
ARGON
CARBON DIOXIDE
CARBON MONOXIDE
NITROUS OXIDE

TOTAL

$$
\begin{aligned}
& \text { N2 . . . . } 79.21 \\
& 02 \text {. . . . } 4.978 \\
& A R \ldots 0.939 \\
& \mathrm{CO} 2 \ldots 14.177 \\
& \mathrm{CO} \text {..... } 0.65 \\
& \mathrm{~N} 20 . . . .0 .044 \\
& ====== \\
& 100.00
\end{aligned}
$$

VARIANCE $=0.29$ PERCENT

NOTE: UNCERTAINTIES ARE ONE STD. DEV. FROM THE 'REGRESSION, ANALYSIS AND DO NOT INCLUDE CONTRIBUTIONS DUE TO

INTENSITY MEASUREMENTS WHICH ADO ABOUT $+1-.2 \%$ OF THE. CONCENTRATION.

COMFUTED UALUES LESS THAN O.01 PERCENT HAVE BEEN OMITTED.

COMPONENTS OMITTED EQUAL TO 0.02 PERCENT OF THE SAMPLE

RESULTS ARE NORMALIZED' AFTER THESE COMPOUNDS ARE REMOVED.

(1) WATER HZO 


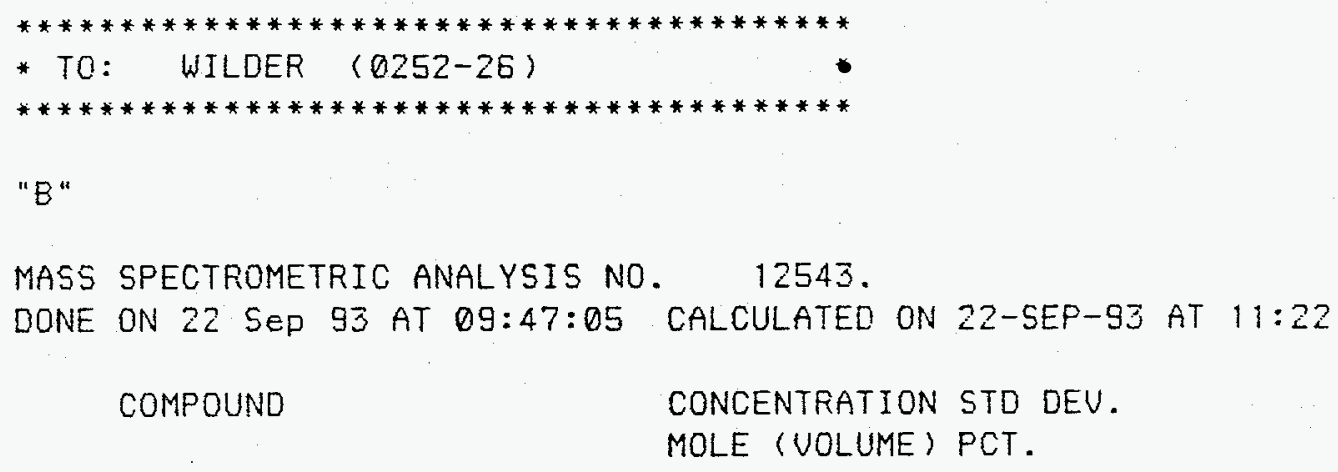

NOTE: UNCERTAINTIES ARE ONE STD. DEU. FROM THE 'REGRESSION, ANALYSIS AND DO NOT INCLUDE CONTRIBUTIONS DUE TO INTENSITY MEASUREMENTS WHICH ADO ABOUT $+1-.2 \%$ 'OF THE. CONCENTRATION.

COMPUTED VALUES LESS THAN O.O1 PERCENT HAVE BEEN OMITTED.

COMPONENTS OMITTED EQUAL TO 0.12 PERCENT OF THE SAMPLE

RESULTS ARE NORMALIZED' AFTER THESE COMPOUNDS ARE REMOVED. (1) WATER HZO 


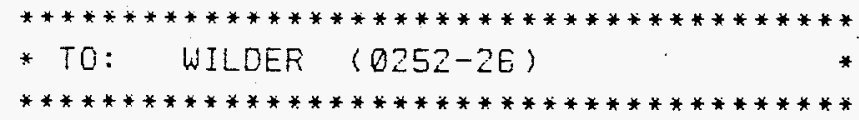

"C" $8: 00 P M \quad 9-20-93$

MASS SPECTROMETRIC ANALYSIS NO. 12544.

DONE ON 22 SEP 93 AT 10:02:16 CALCULATED ON 22-SEP-S3 AT 11:22

COMPOUND

CONCENTRATION STD DEV.

MOLE (UOLUME) PCT.

NITROGEN
OXYGEN
ARGON
CARBON DIOXIDE
CARBON MONOXIDE

TOTAL

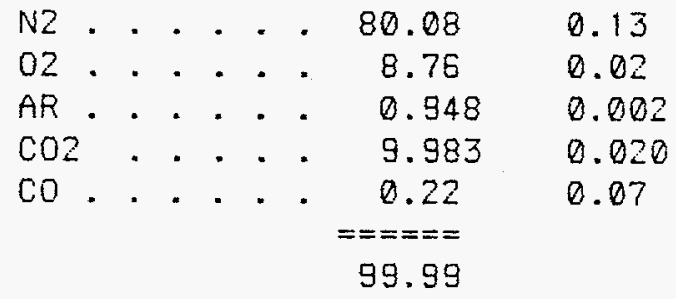

UARIANCE $=0.54$ PERCENT

NOTE: UNCERTAINTIES ARE ONE STD. DEU. FROM THE 'REGRESSION, ANALYSIS AND DO NOT INCLUDE CONTRIBUTIONS DUE TO

INTENSITY MEASUREMENTS WHICH ADD ABDUT $+1-.2 \%$ OF THE. CONCENTRATION.

COMPUTEO VALUES LESS THAN 0.01 PERCENT HAVE BEEN OMITTED.

COMPONENTS OMITTED EQUAL TO 0.16 PERCENT OF THE SAMPLE

RESULTS ARE NORMALIZED' AFTER THESE COMPOUNDS ARE REMOVED.

(1) WATER HZO 


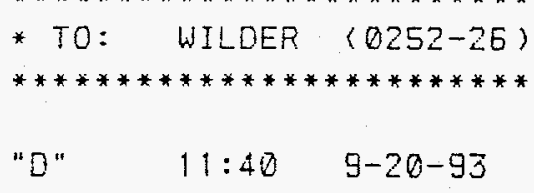

NITROGEN
OXYGEN
ARGON
CARBON DIOXIDE
NITRIC OXIDE

TOTAL

$$
\begin{aligned}
& \text { N2 . . . . } 80.40 \quad 0.12 \\
& 02 \text {..... } 10.340 .02 \\
& \text { AR . . . . } 0.9470 .002 \\
& \mathrm{CO2} \cdot \ldots .298 \quad 0.016 \\
& \text { NO ... } 0.0110 .002 \\
& ====== \\
& 100.00
\end{aligned}
$$

VARIANCE $=0.54$ PERCENT

NOTE: UNCERTAINTIES ARE ONE STD. DEU. FROM THE REGRESSION, ANALYSIS AND DO NOT INCLUDE CONTRIBUTIONS DUE TO INTENSITY MEASUREMENTS WHICH ADD ABOUT $+1-.2 \%$ 'OF THE. CONCENTRATION.

COMPUTED VALUES LESS THAN 0.01 PERCENT HAVE BEEN OMITTED.

COMPONENTS OMITTED EQUAL. TO $0.2 E$ PERCENT OF THE SAMPLE

RESULTS ARE NORMALIZED' AFTER THESE COMPOUNDS ARE REMOVED. (1) WATER H2O 


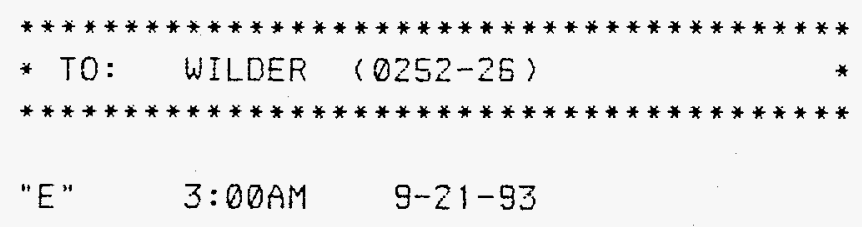

MASS SPECTROMETRIC ANALYSIS NO. 12546.

DONE ON 22 SEP 93 AT 10:32:46 CALCULATED ON 22-5EP-93 AT 11:23

COMPOUNO

CONCENTRATION STD DEU.

MOLE (VOLUME) PCT.

$\begin{array}{ll}1 & \text { NITROGEN } \\ 2 & \text { OXYGEN } \\ 3 & \text { ARGON } \\ 4 & \text { CARBON DIOXIDE } \\ 5 & \text { NITRIC OXIDE }\end{array}$

TOTAL

$$
\begin{aligned}
& \mathrm{N2} \cdot \ldots .+78.22 \\
& 02 . . . \quad 17.94 \\
& \text { AR } .0 .04 \\
& \text { COR } . .0 .002 \\
& \text { CO2.... } 2.893 \quad 0.008 \\
& \text { NO . . . } \begin{array}{cc}
0.011 & 0.002
\end{array} \\
& 100.00
\end{aligned}
$$

UARIANCE $=0.63$ PERCENT

NOTE: UNCERTAINTIES ARE ONE STD. DEV. FROM THE 'REGRESSION, ANALYSIS AND DO NOT INCLUDE CONTRIBUTIONS DUE TO INTENSITY MEASUREMENTS WHICH ADD ABOUT $+1-.2 \%$ OF THE. CONCENTRATION.

COMPUTED UALUES LESS THAN 0.01 PERCENT HAVE BEEN OMITTED. COMPONENTS OMITTED EQUAL TO 0.34 PERCENT OF THE SAMPLE RESULTS ARE NORMALIZED AFTER THESE COMPOUNDS ARE REMOUED. (1) WATER H2O 


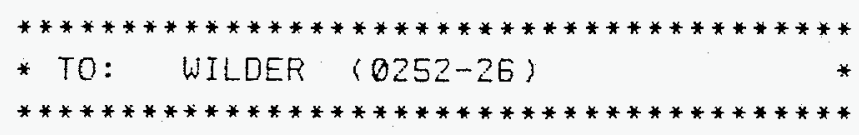

$" F " \quad 6: 50 A M \quad 9-21-93$

MASS SPECTROMETRIC ANALYSIS NO. 12547.

DONE ON 22 SEP 93 AT 10:47:57 CALCULATED ON 22-SEP-93 AT 11:40

COMPOUND

CONCENTRATION STD DEV.

MOLE (UOLUME) PCT.

$\begin{array}{ll}1 & \text { NITROGEN } \\ 2 & \text { OXYGEN } \\ 3 & \text { ARGON } \\ 4 & \text { CARBON DIOXIDE } \\ 5 & \text { NITRIC OXIDE }\end{array}$

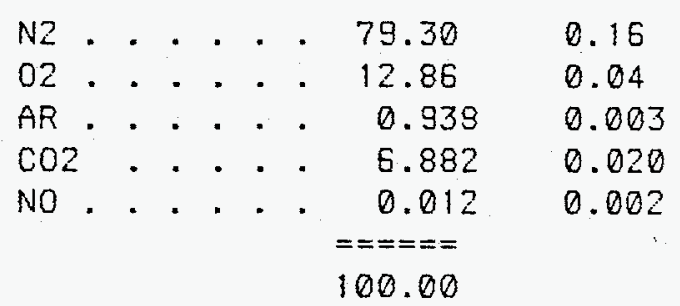

TOTAL

\author{
VARIANCE $=0.93$ PERCENT
}

NOTE: UNCERTAINTIES ARE ONE STD. DEU. FROM THE 'REGRESSION, ANALYSIS AND DO NOT INCLUDE CONTRIEUTIONS DUE TO INTENSITY MEASUREMENTS WHICH ADD ABOUT $+1-.2 \%$ OF THE. CONCENTRATION.

COMPUTED UALUES LESS THAN 0.01 PERCENT HAUE BEEN OMITTED.

COMPONENTS OMITTED EQUAL TO 0.47 PERCENT OF THE SAMPLE

RESULTS ARE NORMALIZED' AFTER THESE COMPOUNDS ARE REMOUED. (1) WATER H2O 


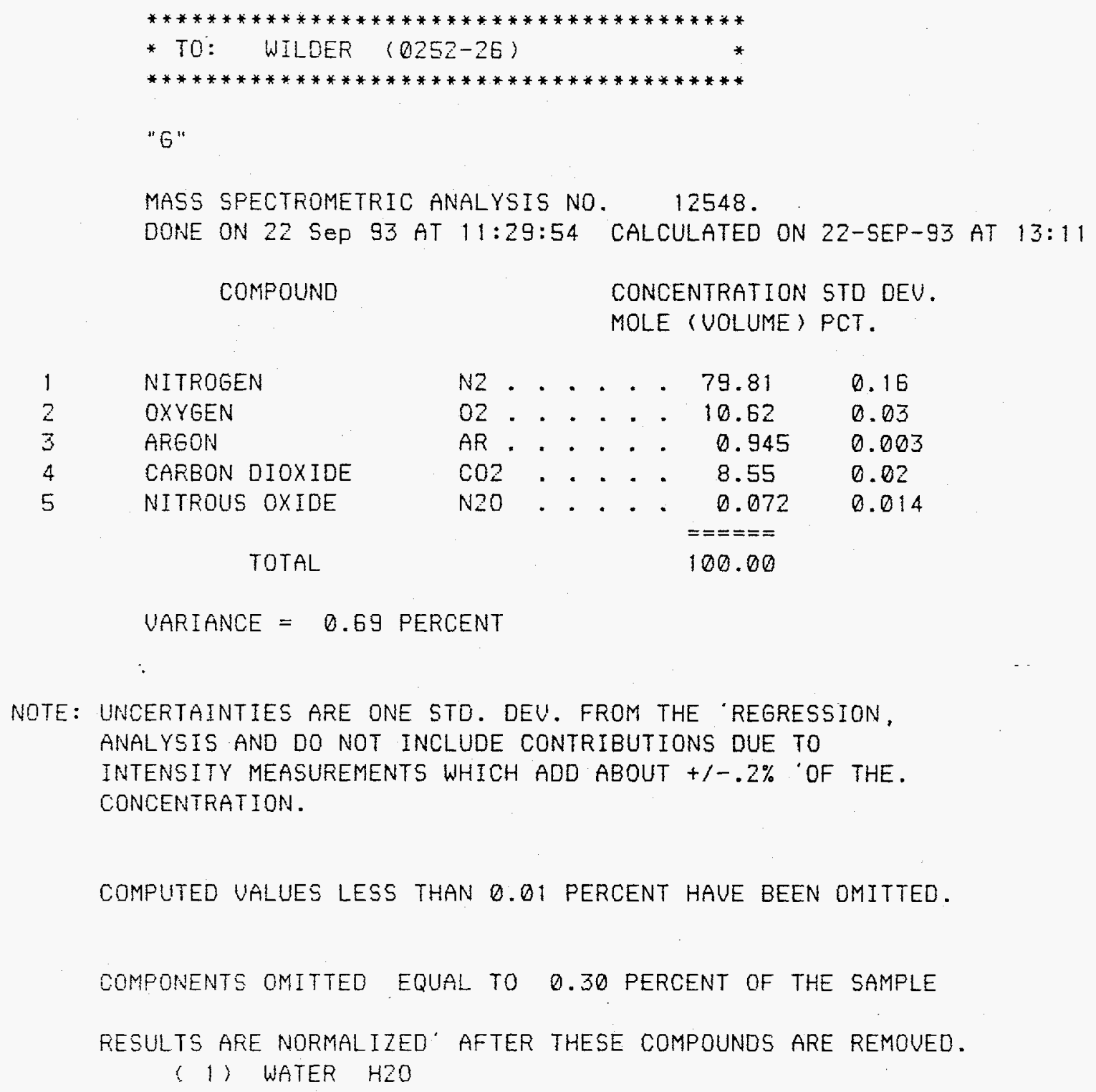




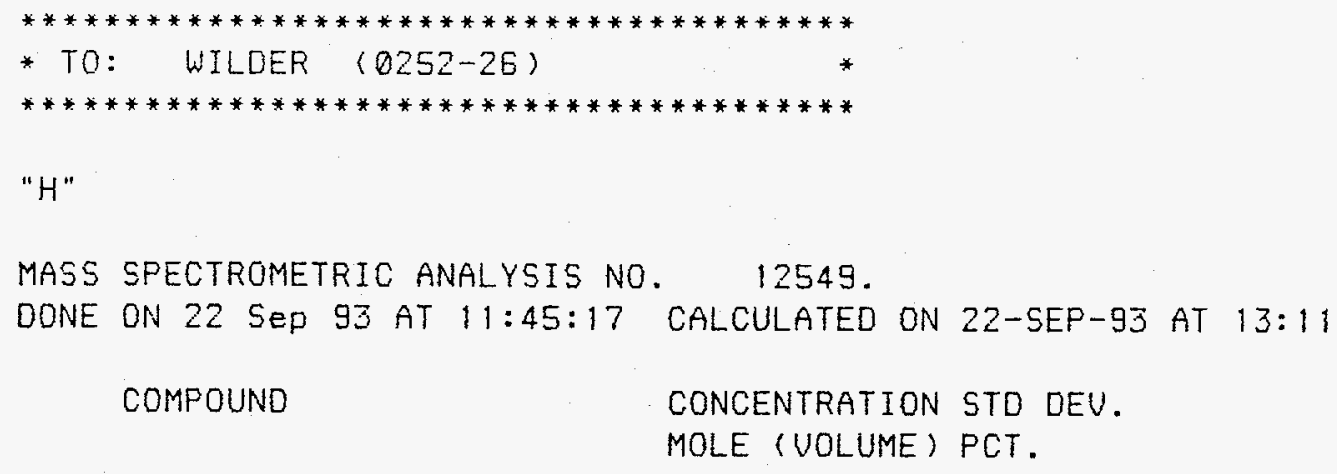

NOTE: UNCERTAINTIES ARE ONE STD. DEV. FROM THE 'REGRESSION, ANALYSIS AND DO NOT INCLUDE CONTRIBUTIONS DUE TO

INTENSITY MEASUREMENTS WHICH ADD ABOUT $+/-.2 \%$ OF THE. CONCENTRATION.

COMPUTED UALUES LESS THAN O. OI PERCENT HAVE BEEN OMITTED.

COMPONENTS OMITTED EQUAL TO 0.43 PERCENT OF THE SAMPLE

RESULTS ARE NORMALIZED' AFTER THESE COMPOUNDS ARE REMOVED. (1) WATER H2O 


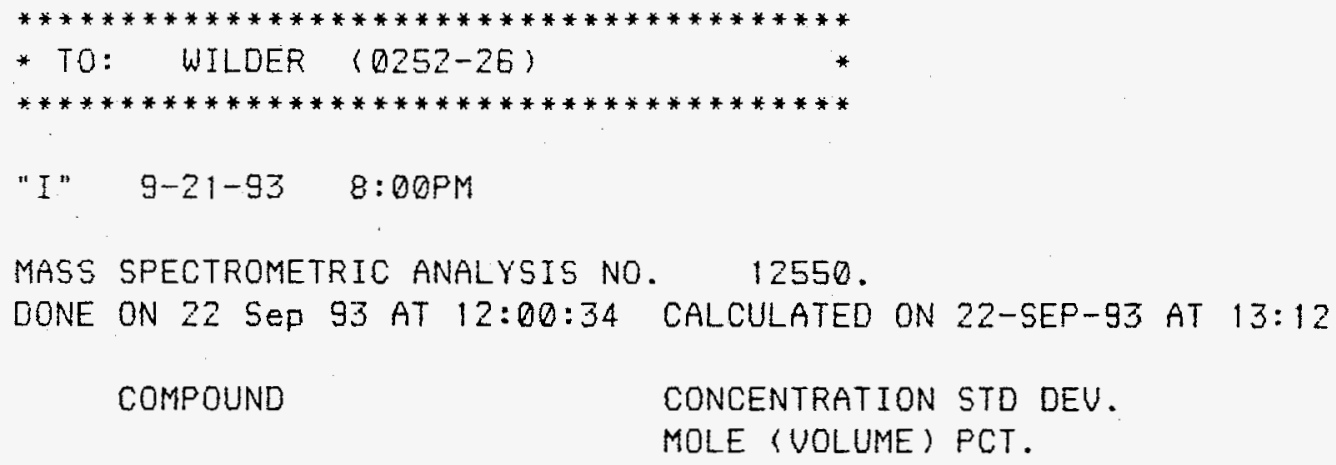

NOTE: UNCERTAINTIES ARE ONE STD. DEU. FROM THE 'REGRESSION, ANALYSIS ANO DO NOT INCLUDE CONTRIBUTIONS DUE TO INTENSITY MEASUREMENTS WHICH ADO AEOUT $+1-.2 \%$ 'OF THE. CONCENTRATION.

COMPUTED VALUES LESS THAN O. 1 PERCENT HAVE BEEN OMITTED.

COMPONENTS OMITTED EQUAL TO 0.36 PERCENT OF THE SAMPLE

RESULTS ARE NORMALIZED' AFTER THESE COMPOUNDS ARE REMOUED. (1) WATER HZO 


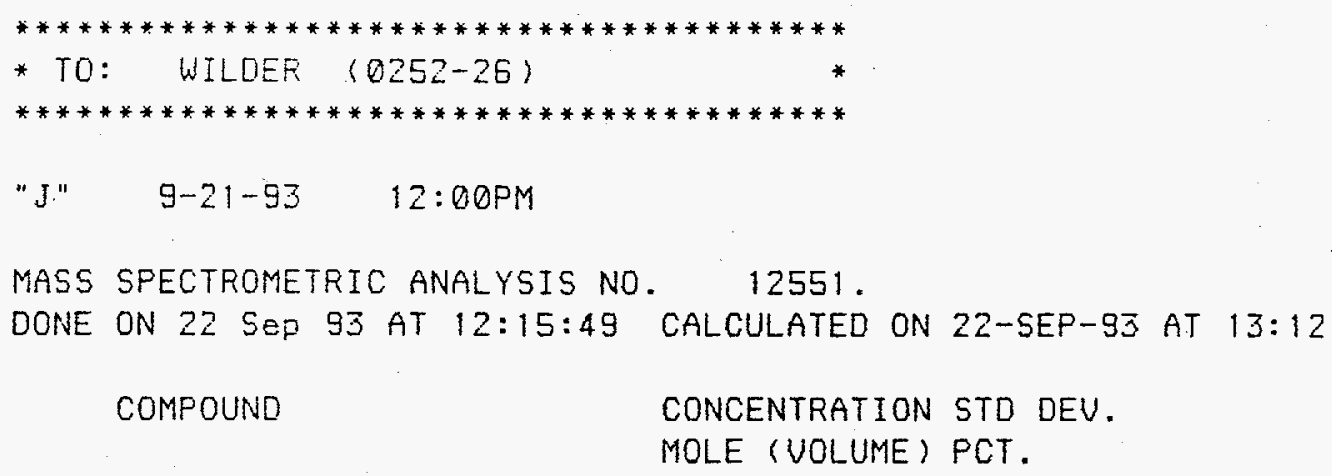

NITROGEN
OXYGEN
fRGON
CARBON DIOXIDE
NITRIC OXIDE

TOTAL

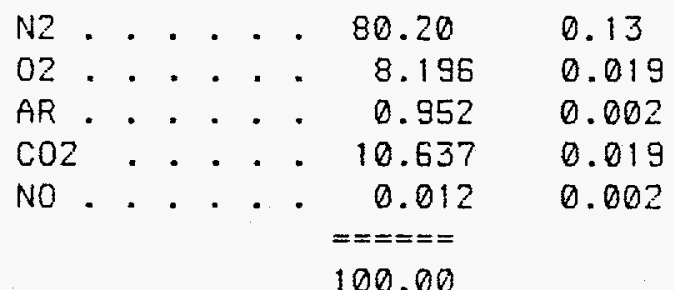

UARIANCE $=0.54$ PERCENT

NOTE: UNCERTAINTIES ARE ONE STD. DEU. FROM THE 'REGRESSION, ANALYSIS AND DO NOT INCLUDE CONTRIBUTIONS DUE TO INTENSITY MEASUREMENTS WHICH ADD ABOUT $+1-.2 \%$ 'OF THE. CONCENTRATION.

COMPUTED VALUES LESS THAN 0.01 PERCENT HAVE BEEN OMITTED.

COMPONENTS OMITTED EQUAL TO 0.37 PERCENT OF THE SAMPLE RESULTS ARE NORMALIZED' AFTER THESE COMPOUNDS ARE REMOVED. (1) WATER H2O 


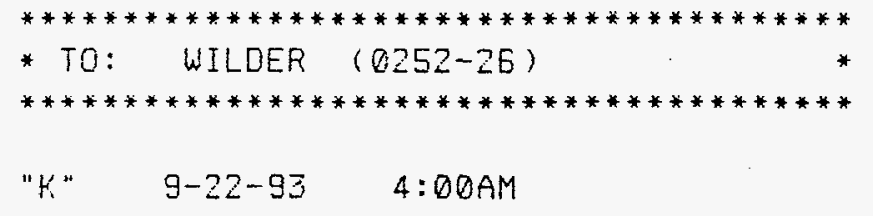

MASS SPECTROMETRIC ANALYSIS NO. 12552.

DONE ON 22 SeP 93 AT 12:31:06 CALCULATED ON 22-SEP-93 AT 13:12

COMPOUND CONCENTRATION STD DEV. MOLE (VOLUME) PCT.

NITROGEN
OXYGEN
ARGON
CARBON OIOXIDE
NITRIC OXIOE
TOTAL

$\mathrm{N} 2 \cdot . \cdot 79.84$

$02 . . . . .10 .74$

0.11

1 NITROGEN

2 OXYGEN

$3 \quad$ ARGON

4

5

TOTAL

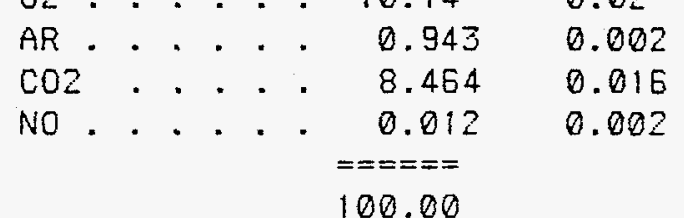

VARIANCE $=0.50$ PERCENT

NOTE: UNCERTAINTIES ARE ONE STD. DEV. FROM THE 'REGRESSION, ANALYSIS AND DO NOT INCLUDE CONTRIBUTIONS DUE TO

INTENSITY MEASUREMENTS WHICH ADO ABOUT $+1-.2 \%$ 'OF THE. CONCENTRATION.

COMPUTEO UALUES LESS THAN 0.01 PERCENT HAUE BEEN OMITTED.

COMPONENTS OMITTED EQUAL TO 0.76 PERCENT OF THE SAMPLE

RESULTS AFE NORMALIZED' AFTER THESE COMPOUNDS ARE REMOUED. (1) WATER H2O 
Two Stage Molten Salt B-241 22 Sep 93 Run MSD:DATA:22 Sep 93 Run TIMING REFERENCES-- VAX Time = 22-SEP-1993 18:21:50.00, Decimal Hours = 18.3638889

9/22/93 6:28:08 PM 18.469352 The time is 1325 hours, 22 Sep 93. We are restarting another "100" (this is wished for) run on the MSD 241 unit. Fuel feed will remain $3 \mathrm{~g} / \mathrm{min}$., combustion air feed will be set at $1.6 \mathrm{scfm}$. Our procedure will be to stop the combustion air and fuel once every 24 hours, heat the exhaust risers on both vessels with an oxy-acetylene "rosebud" until the accumulated salt is melted back into the vessel, and then continue the run.

The previous run was suspended after about 36 hours due to salt obstruction in the exhaust line.

9/22/93 10:29:50 PM 22.507588 It is 2230 hours, 22 Sep 93. All this time has been spent waiting for the 2 nd vessel to reach a high enough temperature so we can start. It is not above $900^{\circ} \mathrm{C}$ but it is molten, so we can get started.

$\begin{array}{llll}9 / 22 / 93 & 10: 33: 31 \mathrm{PM} & 22.558440 & \text { Start the combustion air. } \\ 9 / 22 / 93 & 10: 36: 53 \mathrm{PM} & 22.614796 & \text { Secure the top two heaters of vessel number }\end{array}$

one.

9/22/93 10:38:02 PM 22.633708 Begin rubber feed.

9/22/93 10:51:29 PM 22.858644 Take gas sample \#54.

9/22/93 11:53:37 PM 23.896708

9/22/93 11:57:23 PM 23.959648 salt 2 plug thermal coupler is reading a very high temp. and has been since the restart. Please check the data from the first start up. The $\mathrm{t} / \mathrm{c}$ is reading 3260 degrees.

9/23/93 4:00:03 AM 28.013792 pulling a gas sample; vial \#55 we'll leave the vial open for 15 secounds aqnd then secure the vial and the sample port.

9/23/93 7:22:25 AM 31.395190 Kelly told me that the rubber feed plugged once, at 0650 (about).

9/23/93 7:36:57 AM 31.638037 Added two jars of shedded rubber. This was don't without securing the combustion air or the rubber feed.

9/23/93 7:53:47 AM 31.919352 The salt temperature of vessel one rose about 5 degrees over the last ten minutes. This is abnormal. All other temperatures and pressures remain well within their normal limits. The lower heater current has not increased, in fact it has declined. I've reduced the set temperature 2 degrees. It would appear that the fuel increased somewhat. This is the only explanation I have.

9/23/93 8:01:11 AM 32.042931 Reduced vessel one set point one more degree to

724 degrees.

9/23/93 8:05:33 AM 32.115880 Take gas sample \#3.

9/23/93 8:07:47 AM 32.153176 Reduced vessel one set point one more degree to

723.

9/23/93 3:06:45 PM 39.153046 At 1210 hours, gas sample \#3 taken.

9/23/93 3:21:38 PM 39.401583 Shut down rubber feed and combustion air. Torch the riser of vessel \#1 to clear it of salt.

9/23/93 3:29:12 PM 39.528051 Restart combustion air and rubber feed. No detectable salt buildup in riser, so no torching was necessary. Added three bottles of rubber crumbs to the hopper.

9/23/93 3:57:13 PM 39.996134 
9/23/93 4:04:30 PM 40.117963 removed sample \#55 B.B.

9/23/93 7:41:16 PM 43.739569 Note, gas sample \#3 and \#55 were taken twice. Assume that the first take is probably good but no gas samples have been taken in the last 8 hours. 9/23/93 7:48:02 PM 43.852676 Will take two gas samples at the same time. Sample number 56 is located after the 2nd vessel as all the previous samples were. Number 54 is located at the top of vessel one riser. Take both sample now.

9/23/93 10:57:18 PM 47.014833 feed was turned off while fillingthe hooper we put in 3 bottles of feed material.

9/24/93 12:00:07 AM 48.064019 taking gas sample lable reads 19-25-93

12:00 a.m.

9/24/93 3:58:58 AM 52.054889 taking gas sample \#2; lable reads: \#2 4:00 a.m.

924193.

9/24/93 5:50:40 AM 53.921361 feeder sleeve became clogged about 05:30; we over shot the temp. we are slowly bringing it back down.

9/24/93 6:17:04 AM 54.362009

9/24/93 7:03:08 AM 55.131940 added 2 more jars of feed material.

9/24/93 7:08:29 AM 55.221306 The "Restart CAMAC" idiot sign just appeared an automatically stopped the program log. It is now restarted but we must look at the "Restart" sign forever.

9/24/93 7:28:45 AM 55.559569 Preparing to take two gas samples at 0800. \#51 will be taken at the top of vessel one riser. \#57 will be taken at the usual place, the exhaust line after the cold trap.

9/24/93 7:36:14 AM 55.684616 Salt temperature in vessel one began to rise a little so the set temperature was reduced to compensate. I believe this to be the result of an increased rubber feed rate entering the system. There does not seem to be the consistency from the screw feed that I desire.

9/24/93 7:57:16 AM 56.036486 Take gas samples \#51 and \#57.

9/24/93 8:16:10 AM 56.351801 I probed vessel one riser with my standard probe wire while removing the gas sample bottle. There was no indication of salt buildup.

9/24/93 8:54:11 AM 56.987389 I increased the set point 1 degree to 717

9/24/93 9:17:11 AM 57.371417 I increased the set point one degree to 718

9/24/93 9:58:27 AM 58.061065 I increased the set point one degree to 719

$9 / 24 / 93 \quad 10: 38: 12 \mathrm{AM} \quad 58.724815$ I increased the set point one degree to 720

9/24/93 11:00:50 AM 59.103218 I increased the set point one degree to 721

9/24/93 12:01:20 PM 60.113764 Gas sample - "A" 9-24-93 taken at 1200

9/24/93 12:10:44 PM $\quad 60.271190$ I increased the set point one degree to 722

9/24/93 2:51:05 PM 62.950324 At 1445, the lift line had bridged and plugged in the reducing fittings. Cleared the blockage and reassembled.

9/24/93 4:06:31 PM 16.111667 Take gas sample "B"

9/24/93 4:06:56 PM 16.118565 Add three jars of rubber crumbs to hopper.

9/24/93 6:22:21 PM 18.381051 Feeder clogged B.B.

9/24/93 8:00:15 PM 20.016324 Removed sample "C". B.B.

9/24/93 8:41:22 PM 20.703463 Note : temp. droped for no reason I could see feeder was feeding ? Turned temp. up to compansate. B.B. 
9/24/93 8:45:50 PM 20.778282 Question : Are we using house air and if so ,is the water being filterd out ? This would expliane the clogging of feeder. B.B.

9/24/93 10:47:23 PM 22.809014 Checked top of the exhaust riser of vessel 1. Looked ok. No appreciable buildup of salt. Have decided to forgo melting it back until tomorrow.

9/24/93 10:56:46 PM

hopper.

9/25/93

$12: 14: 36$ AM

22.965907 Add three jars of rubber crumbs to feed

$\# 51$.

9/25/93 3:02:05 AM 27.064444 lisening to the feed through the feed tube, the feed rate has slowed and tapping it with the hammer is not effecting it. Disassembly of the cluge apparati is in order.

9/25/93 3:05:41 AM 27.124676 some of the feed material was clinging on the second step from the bottom of the apparati; the material also appeared to be damp. 9/25/93 3:23:36 AM 27.423991 there is no feed material comming out of the hopper. opening the lid . material had packed, stiring material around and material is now moving again.

9/25/93 4:00:01 AM 28.032579 pulling 4:00 gas sample. lable reads \#52 4:00 a.m. 925193.

9/25/93

5:13:56 AM 29.267005 feed rate was slowing down and the temp. was dropping so I opened the lid to the hopper and stirred the material around.

9/25/93 7:34:57 AM 31.623519 just finished filling the hopper with 3 more jars of feed material.

9/25/93 7:58:35 AM 32.018245 pulling gas sample ,lable reads as: \#53 8:00 a.m.

92503.

9/25/93 11:58:53 AM 36.032986 Removed sample \#1. B.B.

$9 / 25 / 93$

4:00:03 PM 40.062287 Removed sample \#2. B.B.

$9 / 25 / 93$

4:05:36 PM 40.155028

Added 3 jars of rubber. B.B.

9/25/93 5:45:31 PM 41.824606 Observation: it seems that as the hopper

emptys, salt \#1 temp. drops \& the heater nee ds to be raised. After

filling hopper I have noticed the salt \#1 temp. gets hotter \& I needed to drop heater temp.. My conclusion is

the added waight must help the worm feed gear load fuel. 
Two Stage Molten Salt B-241 22 Sep 93 Run Cont. . MSD:DATA:22 Sep 93 Run Cont. TIMING REFERENCES-- VAX Time = 25-SEP-1993 18:49:57.00, Decimal Hours = 18.8325000

9/25/93 6:55:31 PM 18.925042 This is the continuation of 22 Sep 93 Run. It is now 1855 , Saturday.

9/25/93 6:56:21 PM 18.939319 I attempted to look at the data file with Word while the application was running. It caused the LabView application to shut down.

9/25/93 7:31:13 PM 19.521718 Hopper clogged at reducer . B.B.

9/25/93 8:00:04 PM 20.003792 pulled gas sample lable reads as : \#3

9/25/93 11:57:46 PM 23.975292 pulling gas sample ;lable reads :\#4 12:00 a.m.

92603.

$9 / 26 / 93$

92633.

9/26/93 6:02:03 AM 30.061583 filled up hopper with 3 jars of feed material time 6:02 a.m.

9/26/93 8:00:11 AM 32.035171 Take gas sample \#6.

9/26/93 8:08:13 AM 32.169495 Bill Sawyer has just arrived and has been briefed on the operation.

9/26/93 1:22:22 PM 37.418046 Combustion air and fuel feed stopped due to excessive vessel pressure in vessel number one.

9/26/93 1:54:17 PM 37.951403 Completed heating the exhaust risers in both vessels. The riser of vessel two appears to have been the blocked passage. Restarted combustion air and rubber feed.

9/26/93 2:06:30 PM 38.155144 Secured fuel feed and combustion air flow. It appears that the exhaust riser in vessel one is still plugged.

9/26/93 3:03:23 PM 39.105787 About an hour was used to melt out the riser. It appears as if a "blob" of salt was pushed up into the riser in a very short period of time. It is hoped that it is clear now.

9/26/93 3:09:27 PM 39.207333 There appears to still be a blockage in the exhaust line. I am shutting down the experiment. We will allow the units to cool and inspect. 


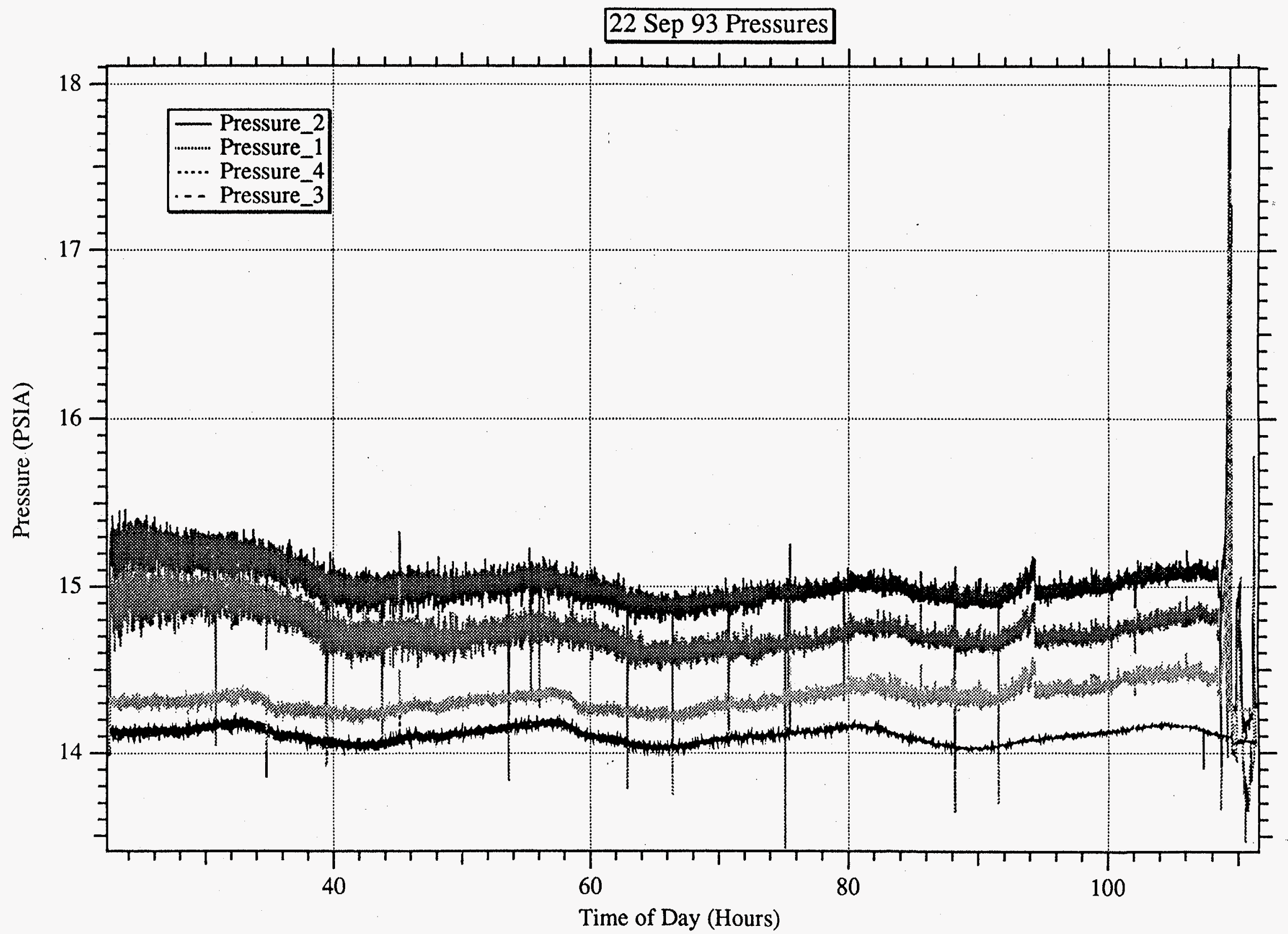


Temperature (Degrees C)

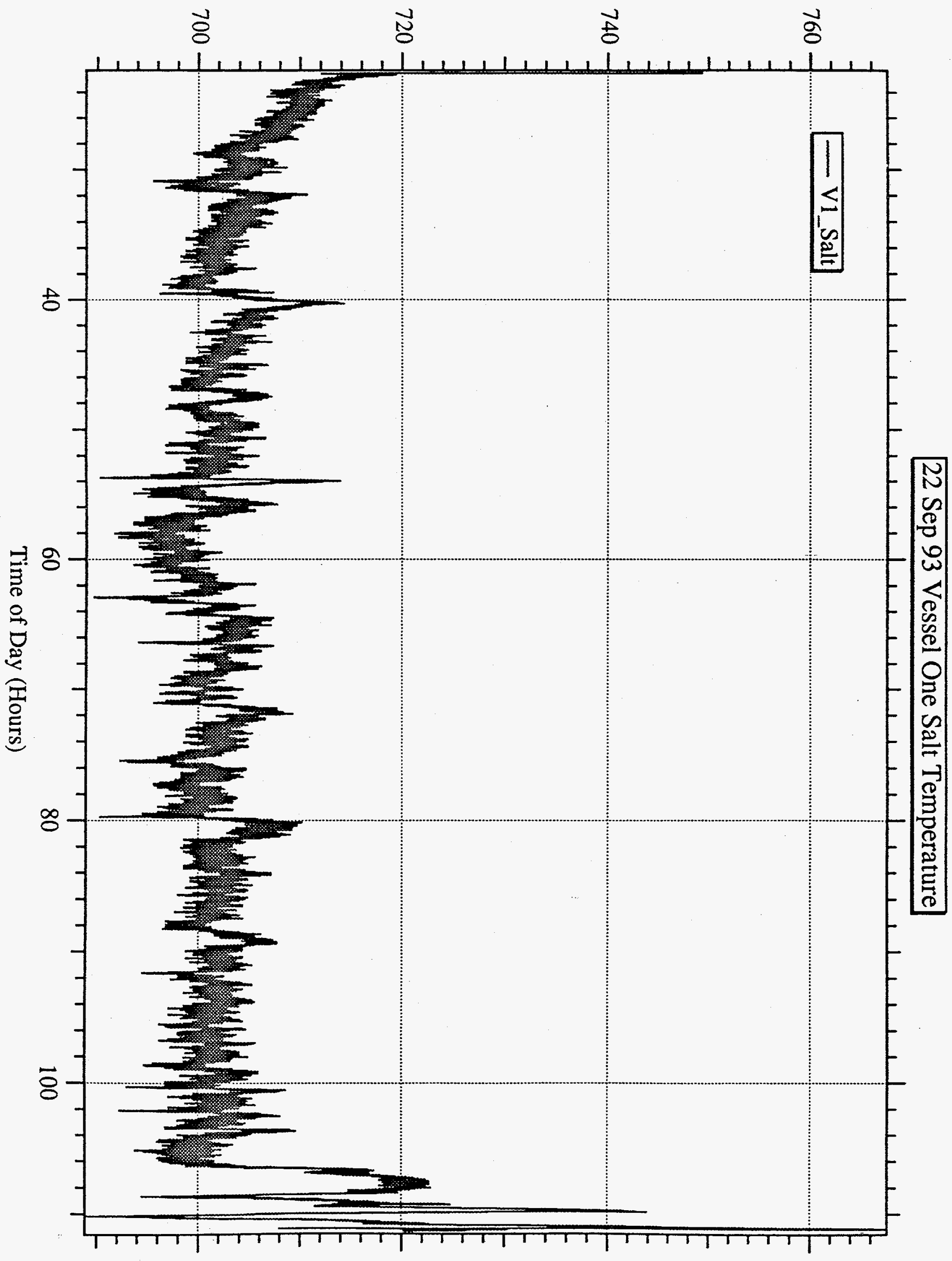




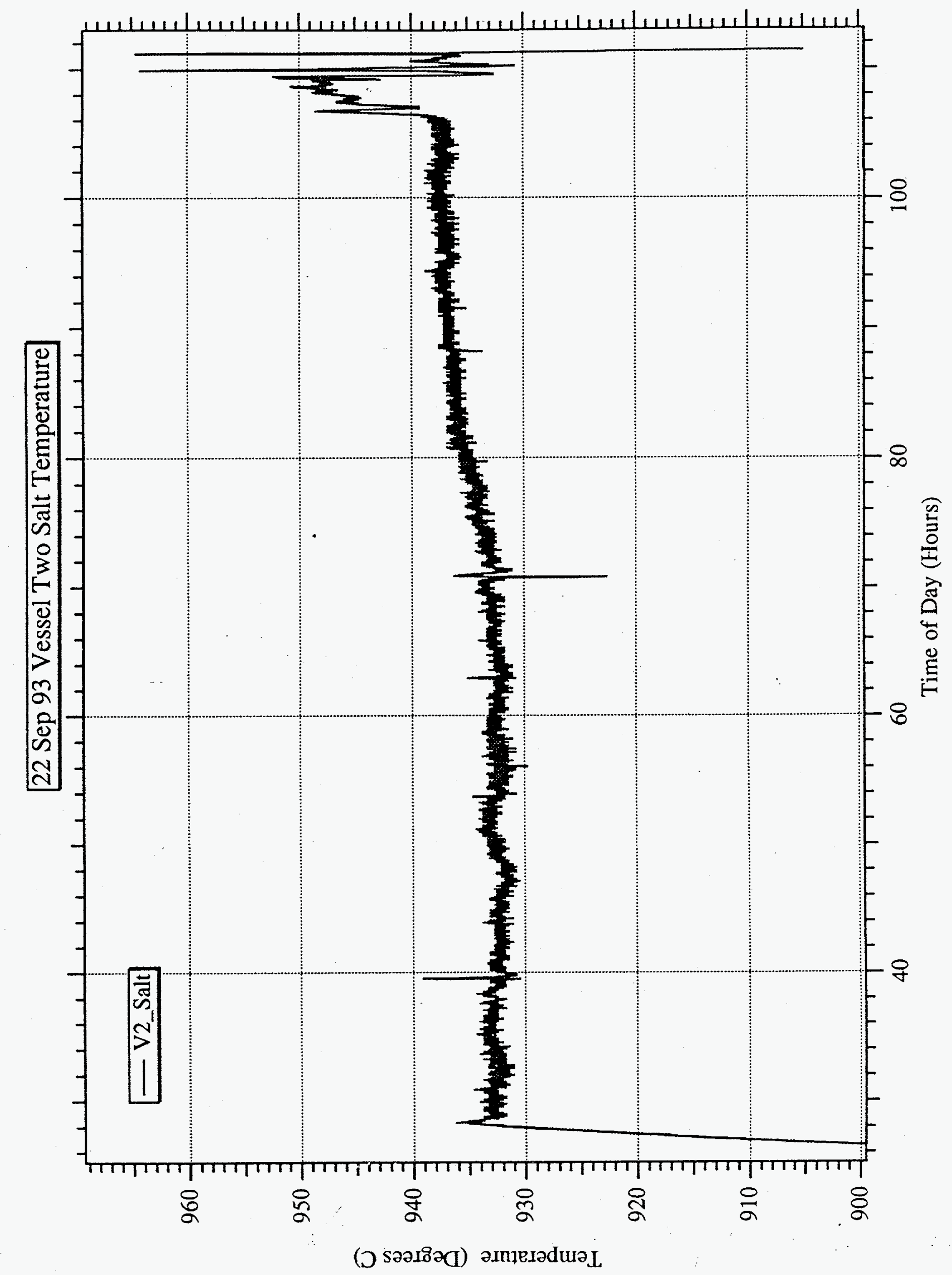




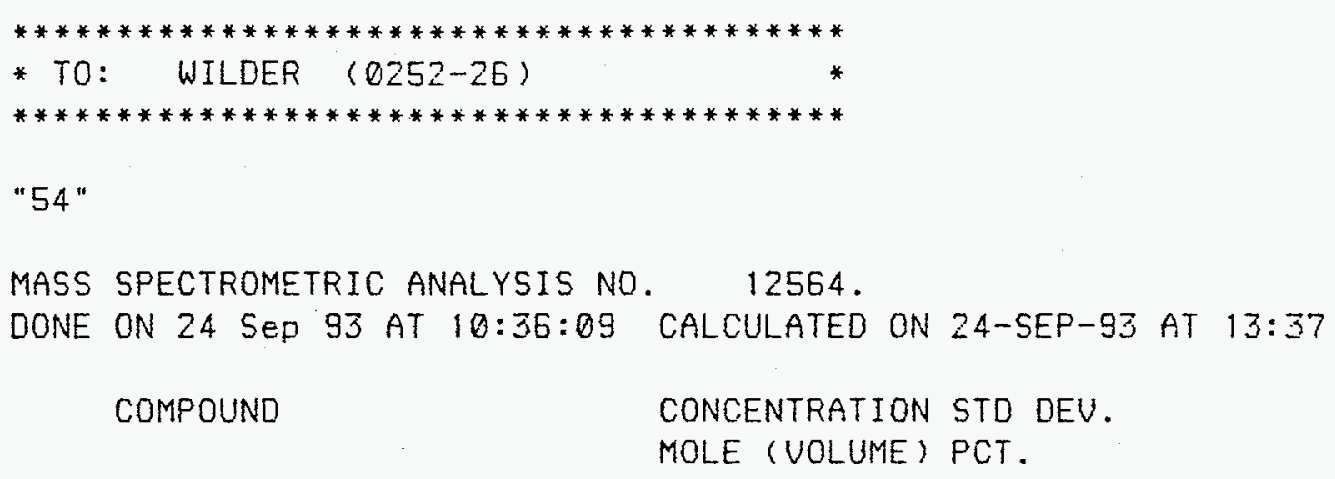

NOTE: UNCERTAINTIES ARE ONE STD. DEU. FROM THE 'REGRESSION, ANALYSIS AND DO NOT INCLUDE CONTRIBUTIONS DUE TO INTENSITY MEASUREMENTS WHICH ADD ABOUT $+/-.2 \%$ 'OF THE. CONCENTRATION.

COMPUTED UALUES LESS THAN 0.01 PERCENT HAVE BEEN OMITTED.

COMPONENTS OMITTED EQUAL TO 0.22 PERCENT OF THE SAMPLE RESULTS ARE NORMALIZEO' AFTER THESE COMPOUNDS ARE REMOUED. (1) WATER H2O 


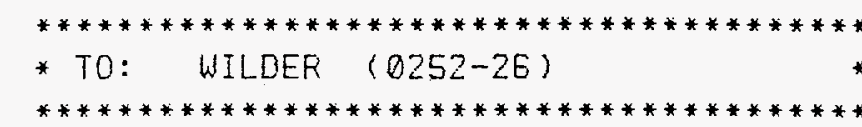

" 55 "

MASS SPECTROMETRIC ANALYSIS NO. 12565.

DONE ON 24 SEP 93 AT 10:51:27 CALCULATED ON 24-SEP-93 AT 13:37

COMPOUND

CONCENTRATION STD DEV.

MOLE (VOLUME) PCT.

NITROEEN
OXYGEN
ARGON
CARBON DIOXIDE
CAREON MONOXIDE
NITRIC OXIDE

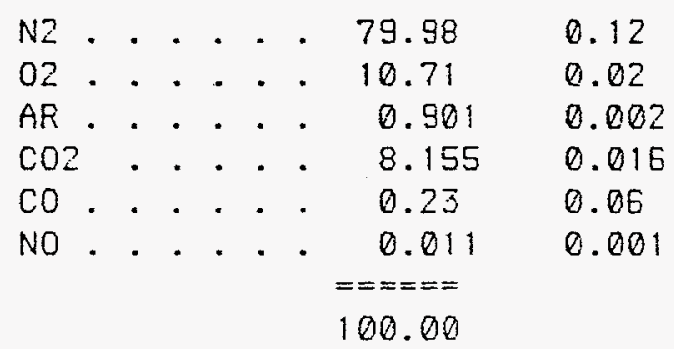

UARIANCE $=0.52$ PERCENT

NOTE: UNCERTAINTIES ARE ONE STD. DEU. FROM THE 'REGRESSION, ANALYSIS AND DO NOT INCLUDE CONTRIBUTIONS DUE TO

INTENSITY MEASUREMENTS WHICH ADD ABOUT $+1-.2 \%$ 'OF THE. CONCENTRATION.

COMFUTED VALUES LESS THAN 0.01 PERCENT haVE BEEN OMITTED.

COMPONENTS OMITTED EQUAL TO 0.18 PERCENT OF THE SAMPLE

RESULTS ARE NORMALIZED' AFTER THESE COMPOUNDS ARE REMOVED. (1) WATER HZO 


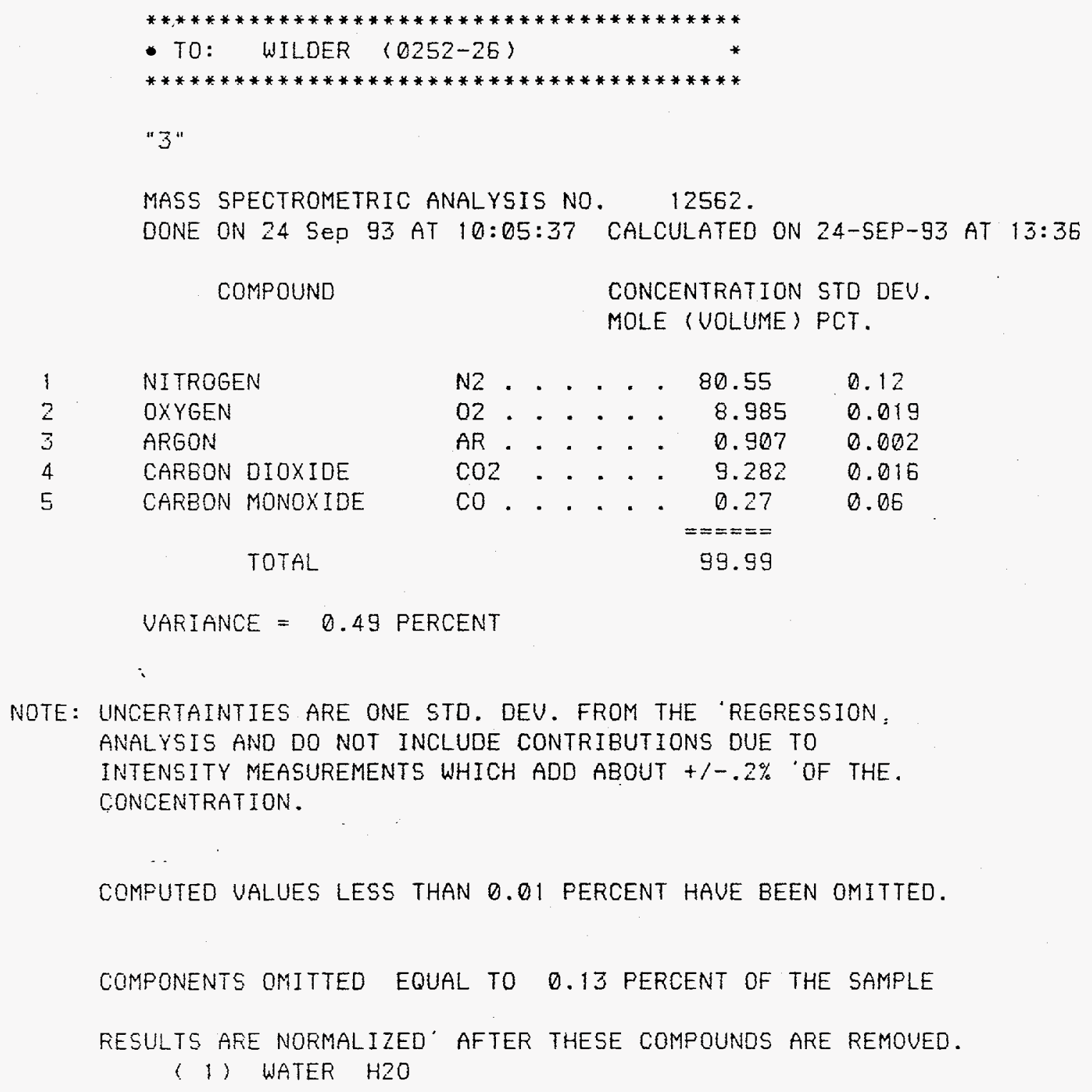

Orax Fenbarid 


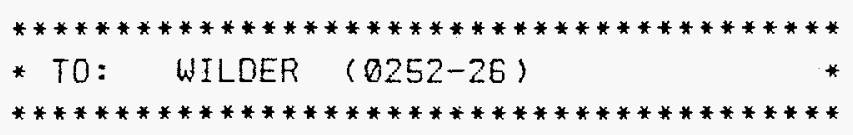

" $56 "$

MASS SPECTROMETRIC ANALYSIS NO. 12566.

DONE ON 24 SeP 93 AT 11:23:15 CALCULATED ON 24-SEP-93 AT 13:47

COMPOUND

CONCENTRATION STD DEU.

MOLE (VOLUME) PCT.

NITROGEN
OXYGEN
ARGON
CARBON DIOXIDE
CARBON MONOXIDE
NITRIC OXIDE

TOTAL

$$
\begin{aligned}
& \text { N2 . . . } 80.60 \quad 0.12 \\
& 02 \ldots . . .8 .663 \quad 0.018 \\
& \text { AR . . . . } 0.9120 .002 \\
& \mathrm{CO} 2 \ldots .9 .553 \quad 0.017 \\
& \text { CO..... } 0.260 .06 \\
& \text { NO . . . } 0.011 \cdot 0.001 \\
& 100.00
\end{aligned}
$$

VARIANCE $=0.49$ PERCENT

NOTE: UNCERTAINTIES ARE ONE STD. DEU. FROM THE 'REGRESSION: ANALYSIS AND DO NOT INCLUDE CONTRIBUTIONS DUE TO INTENSITY MEASUREMENTS WHICH ADD ABOUT $+1-.2 \%$ 'OF THE. CONCENTRATION.

COMPUTED VALUES LESS THAN 0.01 PERCENT HaVE BEEN OMITTED.

COMPONENTS OMITTED EOUAL TO 0.07 PERCENT OF THE SAMPLE RESULTS ARE NORMALIZED' AFTER THESE COMPOUNDS ARE REMOVED. (1) WATER H2O 


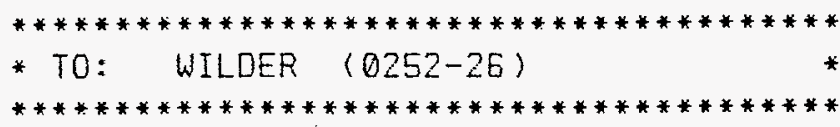

"1" 12:00AM $9 / 24 / 93$

MASS SPECTROMETRIC ANALYSIS NO. 12560.

DONE ON 24 SEP 93 AT 09:35:05 CALCULATED ON 24-SEP-93 AT 13:36

COMPOUND

CONCENTRATION STD DEU.

MOLE (VOLUME) PCT.

NITROGEN
OXYGEN
ARGON
CARBON DIOXIDE
CARBON MONOXIDE

TOTAL

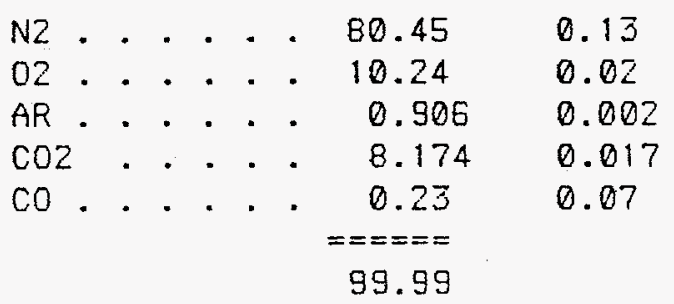

VARIANCE $=0.56$ PERCENT

NOTE: UNCERTAINTIES ARE ONE STD. DEU. FROM THE 'REGRESSION, ANALYSIS AND DO NOT INCLUDE CONTRIBUTIONS DUE TO INTENSITY MEASUREMENTS WHICH ADD ABOUT $+/-.2 \%$ 'OF THE. CONCENTRATION.

COMPUTED UALUES LESS THAN 0.01 PERCENT HAVE BEEN OMITTED.

COMPONENTS OMITTED EQUAL TO 0.02 PERCENT OF THE SAMPLE

RESULTS ARE NORMALIZED' AFTER THESE COMPOUNDS ARE REMOUED. (1) WATER H2O 


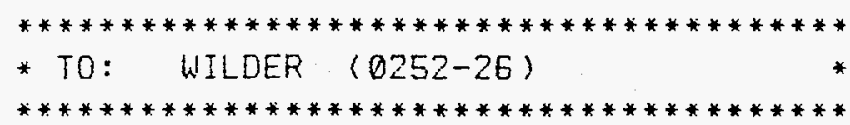

$" 2 " \quad 4: 00 A M \quad 9 / 24 / 93$

MASS SPECTROMETRIC ANALYSIS NO. 12561.

DONE ON 24 SeP 93 AT $99: 50: 21$ CALCULATED ON 24-SEP-93 AT 14:19

COMPOUND CONCENTRATION STD DEV.

MOLE (VOLUME) PCT.

$\begin{array}{ll}1 & \text { NITROGEN } \\ 2 & \text { OXYGEN } \\ 3 & \text { ARGON } \\ 4 & \text { CARBON DIOXIDE } \\ 5 & \text { CARBON MONOXIDE } \\ 6 & \text { NITRIC OXIDE }\end{array}$

TOTAL

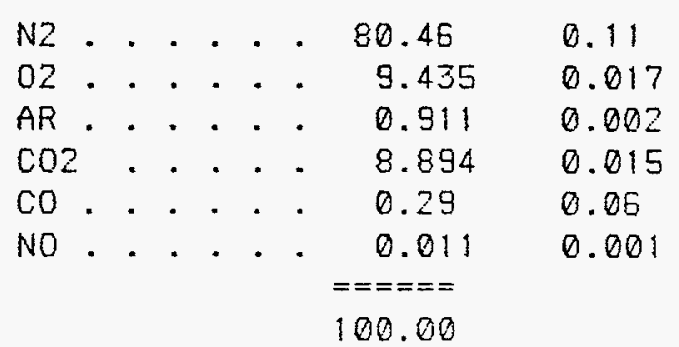

VARIANCE $=0.45$ PERCENT

NOTE: UNCERTAINTIES ARE ONE STD. DEU. FROM THE 'REGRESSION, ANALYSIS AND DO NOT INCLUDE CONTRIBUTIONS DUE TO

INTENSITY MEASUREMENTS WHICH ADD ABOUT $+1-.2 \%$ 'OF THE. CONCENTRATION.

COMPUTED UALUES LESS THAN 0.01 PERCENT HAVE BEEN OMITTEO.

COMFONENTS OMITTED EQUAL TO 0.07 PERCENT OF THE SAMPLE

RESULTS ARE NORMALIZED' AFTER THESE COMPOUNOS ARE REMOUED.

(1) WATER H2O 


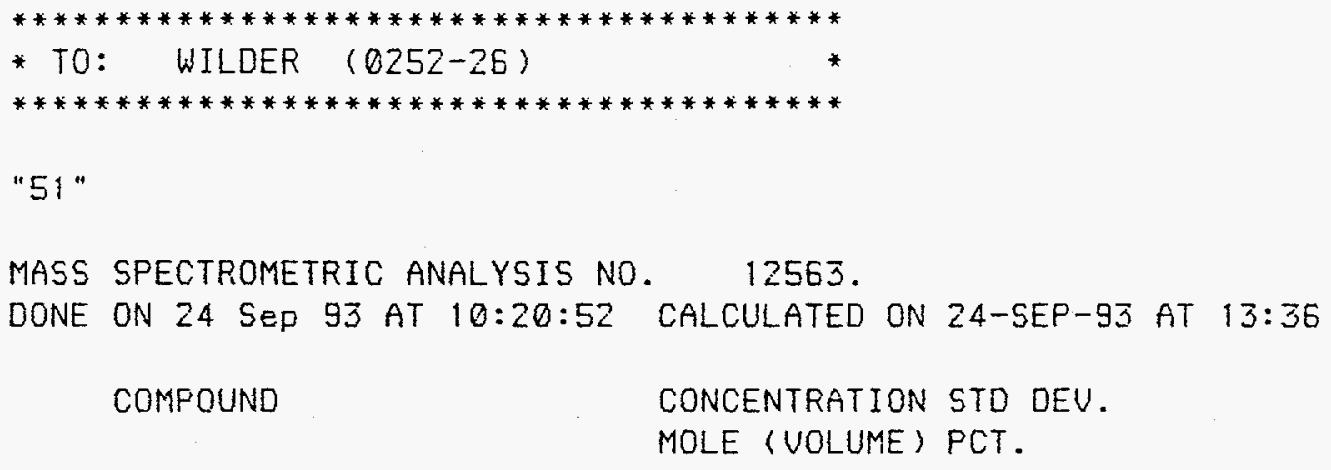

NOTE: UNCERTAINTIES ARE ONE STD. DEU. FROM THE 'REGRESSION, ANALYSIS AND DO NOT INCLUDE CONTRIBUTIONS DUE TO

INTENSITY MEASUREMENTS WHICH ADD ABOUT $+1-.2 \%$ OF THE. CONCENTRATION.

COMPUTED VALUES LESS THAN 0.01 PERCENT haVE BEEN OMITTEO. COMPONENTS OMITTED EQUAL TO 0.19 PERCENT OF THE SAMPLE RESULTS ARE NORMALIZEO' AFTER THESE COMPOUNDS ARE REMOUED. (1) WATER HZO 


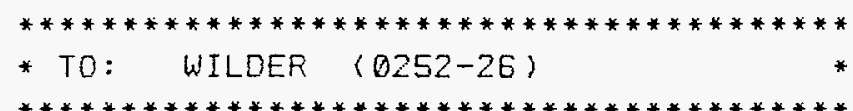

"57"

MASS SPECTROMETRIC ANALYSIS NO. 12567.

DONE ON 24 SEP 93 AT $11: 38: 31$ CALCULATED ON 24-SEP-93 AT 14:30

COMPOUND

CONCENTRATION STD DEU. MOLE (VOLUME) PCT.

NITROGEN
OXYGEN
ARGON
CARBON OIOXIDE
NITRIC OXIDE
TOTAL

N2 . . . 81.16

0.16

2

3

4

TOTAL

$$
\begin{aligned}
& 02 . . . .8 .05 \quad 0.05 \\
& \text { AR . . . . } 0.9110 .003 \\
& \mathrm{CO2} \cdot . . .9 .87 \quad 0.02 \\
& \text { NO . . . } .0 .015 \quad 0.002 \\
& ===== \\
& 100.00
\end{aligned}
$$

VARIANCE $=0.75$ PERCENT

NOTE: UNCERTAINTIES ARE ONE STO. DEV. FROM THE 'REGRESSION, ANALYSIS AND DO NOT INCLUDE CONTRIBUTIONS DUE TO

INTENSITY MEASUREMENTS WHICH ADD ABOUT $+1-.2 \%$ 'OF THE. CONCENTRATION.

COMPUTED VALUES LESS THAN 0.01 PERCENT HAVE BEEN OMITTED.

COMPONENTS OMITTED EQUAL TO 0.11 PERCENT OF THE SAMPLE

RESULTS ARE NORMALIZED' AFTER THESE COMPOUNOS ARE REMOUEO. (i) WATER H2O 


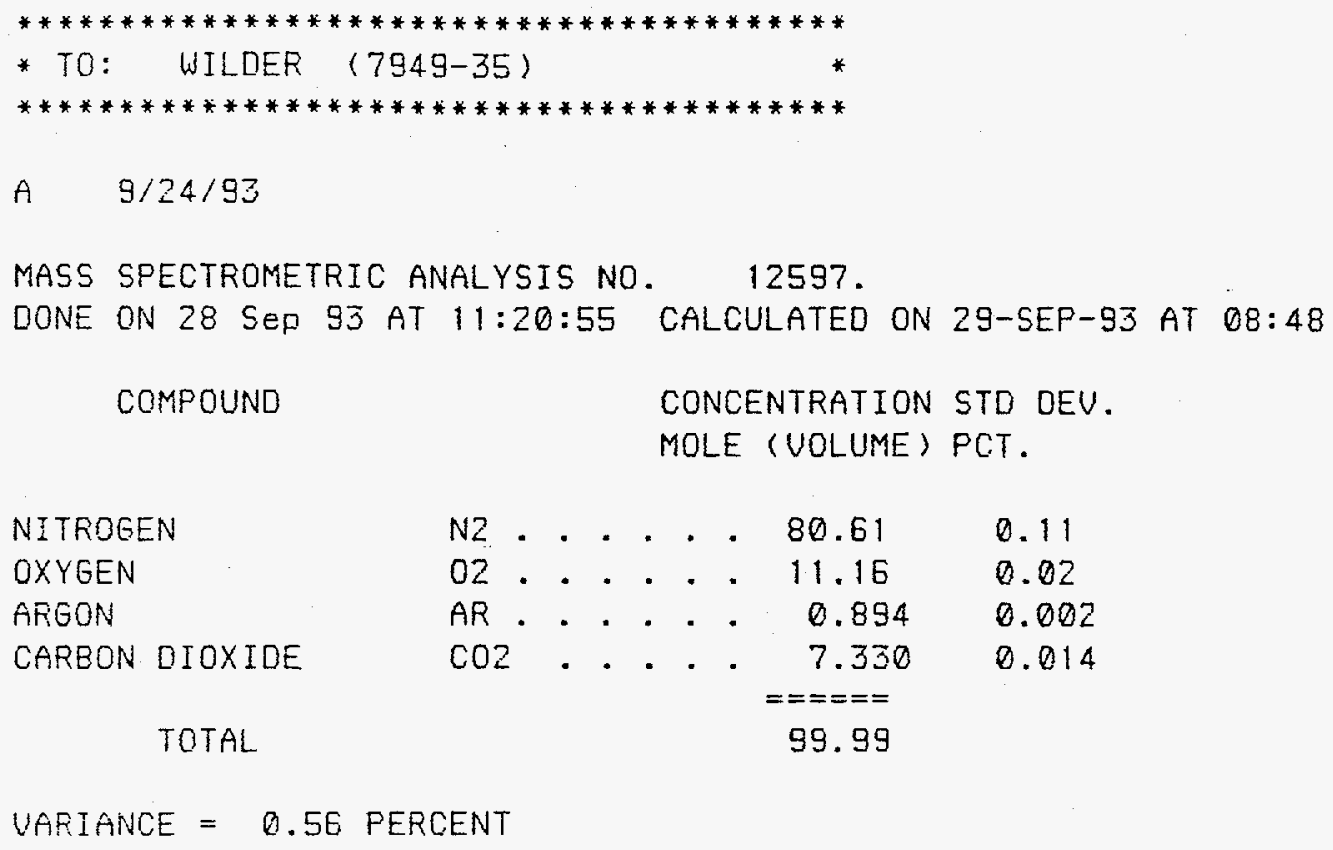

UARIANCE $=0.56$ PERCENT

NOTE: UNCERTAINTIES ARE ONE STD. DEU. FROM THE 'REGRESSION, ANALYSIS ANO DO NOT INCLUDE CONTRIBUTIONS DUE TO INTENSITY MEASUREMENTS WHICH ADD ABOUT $+1-.2 \%$ 'OF THE. CONCENTFATION.

COMPUTED VALUES LESS THAN 0.01 PERCENT HAUE BEEN OMITTED.

COMPONENTS OMITTED EQUAL TO 0.29 PERCENT OF THE SAMPLE

RESULTS ARE NORMALIZEO' AFTER THESE COMPOUNDS ARE REMOVED. (1) WATER H2O 


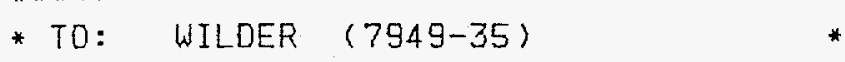

B $\quad 9 / 24 / 93$

MASS SPECTROMETRIC ANALYSIS NO. 12598.

DONE ON 28 SEP 93 AT 11:36:05 CALCULATED ON 29-5EP-93 AT 08:49

COMPOUND CONCENTRATION STO DEV. MOLE (VOLUME) PCT.

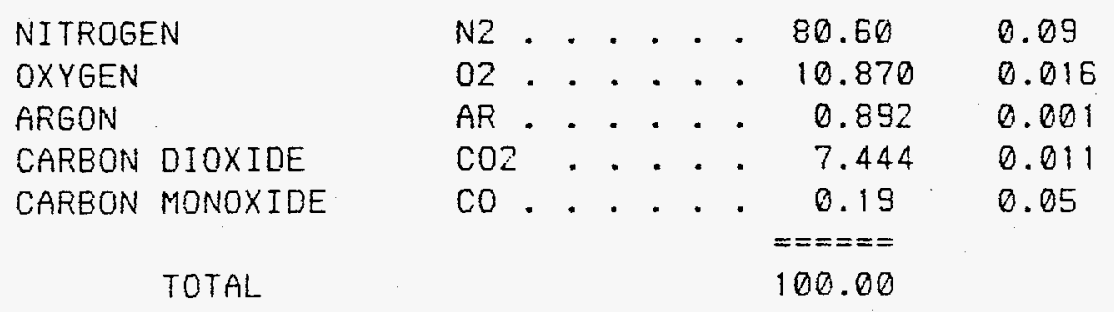

VARIANCE $=0.37$ PERCENT

NOTE: UNCERTAINTIES ARE ONE STO. DEV. FROM THE 'REGRESSION: ANALYSIS AND DO NOT INCLUDE CONTRIBUTIONS DUE TO

INTENSITY MEASUREMENTS WHICH ADD ABOUT $+1-.2 \%$ 'OF THE. CONCENTRATION.

COMPUTED VALUES LESS THAN 0.01 PERCENT HAVE BEEN OMITTEO.

COMPONENTS OMITTEO EQUAL TO 0.34 PERCENT OF THE SAMPLE

FESULTS ARE NORMALIZED' AFTER THESE COMPOUNDS ARE REMOUED.

(1) WATER H2O 


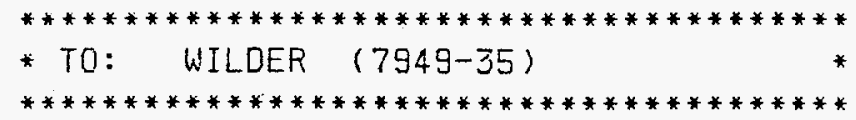

C

MASS SPECTROMETRIC ANALYSIS NO. 12599.

DONE ON 28 SeP 93 AT 12:31:04 CALCULATED ON 29-5EP-93 AT D8:49

COMPOUND

CONCENTRATION STD DEV.

MOLE (VOLUME) PCT.

NITROGEN
OXYGEN
ARGON
CARBON OIOXIDE
TOTAL

N2 . . 81.98

0.11

1 NITROGEN

$$
02
$$

$02 \ldots 5.587$

0.012

3 ARGON

AR . ... 0.907

$\mathrm{CO} 2 . . .11 .520$

0.002

4

VARIANCE $=0.50$ PERCENT

NOTE: UNCERTAINTIES ARE ONE STD. DEV. FROM THE 'REGRESSION, ANALYSIS AND DO NOT INCLUDE CONTRIBUTIONS DUE TO

INTENSITY MEASUREMENTS WHICH ADD ABOUT $+/-.2 \%$ 'OF THE. CONCENTRATION.

COMPUTED VALUES LESS THAN 0.01 PERCENT HAVE BEEN OMITTED.

COMPONENTS OMITTED EQUAL TO 0.05 PERCENT OF THE SAMPLE

RESULTS ARE NORMALIZED' AFTER THESE COMPOUNDS ARE REMOUED. (1) WATER HZO 


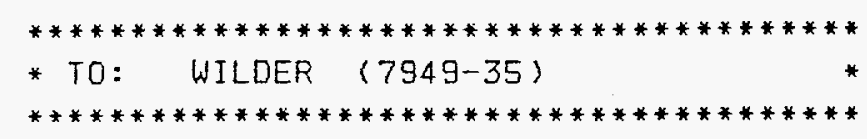

\section{\#52 4:00AM $9 / 25 / 93$}

MASS SPECTROMETRIC ANALYSIS NO. 12595.

DONE ON 28 SEP 93 AT 10:50:31 CALCULATED ON 29-SEP-33 AT 08:48

COMPOUND

CONCENTRATION STO DEV. MOLE (UOLUME) PCT.

NITROGEN
OXYGEN
ARGON
CARBON DIOXIDE
CARBON MONOXIDE
NITRIC OXIDE
TOTAL

\begin{tabular}{|c|c|c|c|c|c|c|}
\hline$N 2$ & . . & . & . & . & 80.79 & 0.05 \\
\hline 02 & . . & . & . & - & 9.591 & 0.014 \\
\hline AR & . & . & . & . & 0.895 & 0.001 \\
\hline $\mathrm{COZ}$ & . & . & . & . & 8.608 & 0.012 \\
\hline $\mathrm{CO}$ &. & . & . & . & 0.11 & 0.04 \\
\hline NO & . . & . & . & . & $\begin{array}{r}0.011 \\
====== \\
100.00\end{array}$ & 0.001 \\
\hline
\end{tabular}

VARIANCE $=0.36$ PERCENT

NOTE: UNCERTAINTIES ARE ONE STD. DEV. FROM THE 'REGRESSION, ANALYSIS AND DO NOT INCLUDE CONTRIBUTIONS DUE TO INTENSITY MEASUREMENTS WHICH ADD ABOUT + $1-.2 \%$ 'OF THE. CONCENTRATION.

COMPUTED UALUES LESS THAN O. OI PERCENT HAUE BEEN OMITTED.

COMPONENTS OMITTED EQUAL TO 0.12 PERCENT OF THE SAMPLE RESULTS ARE NORMALIZED' AFTER THESE COMPOUNDS ARE REMOVED. (1) WATER H2O 


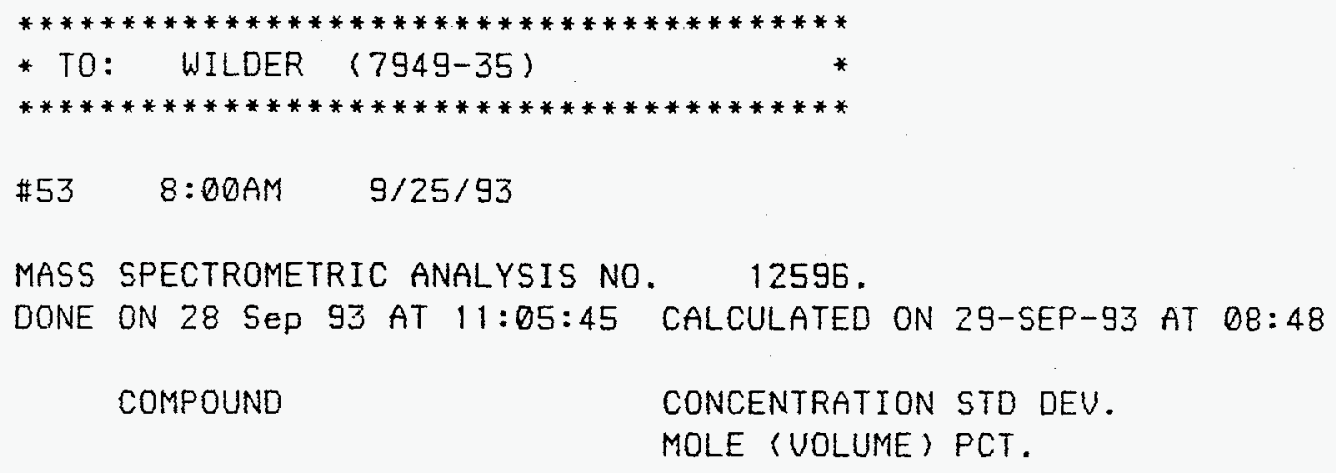

NOTE: UNCERTAINTIES ARE ONE STD. DEU. FROM THE REGRESSION, ANALYSIS AND DO NOT INCLUDE CONTRIBUTIONS DUE TO INTENSITY MEASUREMENTS WHICH ADO ABOUT $+1-.2 \%$ OF THE. CONCENTRATION.

COMPUTED UALUES LESS THAN 0.01 PERCENT HAUE BEEN OMITTED.

COMPONENTS OMITTED EQUAL TO 0.20 PERCENT OF THE SAMPLE

RESULTS ARE NORMALIZED' AFTER THESE COMPOUNDS ARE REMOUED. (1) WATER HZO 


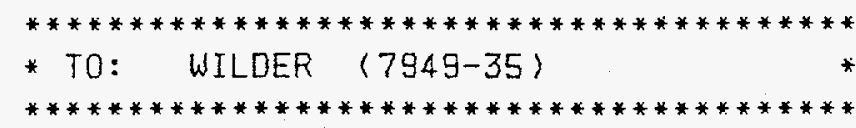

$\# 1$

MASS SPECTROMETRIC ANALYSIS NO. 12579.

DONE ON 27 Sep 93 AT 12:24:20 CALCULATED ON 29-SEP-93 AT 08:34

COMPOUND

CONCENTRATION STD DEV. MOLE (UOLUME) PCT.

NITROGEN
OXYGEN
ARGON
CAREON DIOXIDE
HELIUM

TOTAL

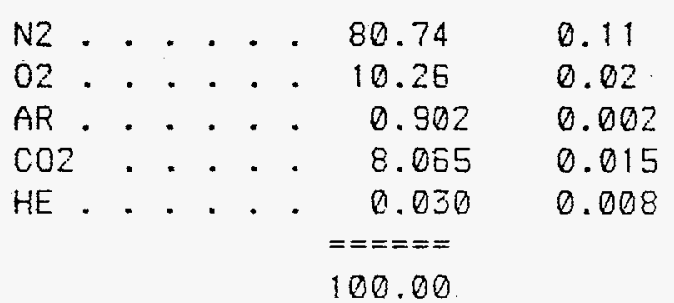

VARIANCE $=0.55$ PERCENT

NOTE: UNCERTAINTIES ARE ONE STO. DEU. FROM THE 'REGRESSION, ANALYSIS AND DO NOT INCLUDE CONTRIBUTIONS DUE TO INTENSITY MEASUREMENTS WHICH ADO ABOUT $+1-.2 \%$ OF THE. CONCENTRATION.

COMPUTED UALUES LESS THAN 0.01 PERCENT HAUE BEEN OMITTED.

COMPONENTS OMITTED EQUAL TO 0.03 PERCENT OF THE SAMPLE

RESULTS ARE NORMALIZED' AFTER THESE COMPOUNDS ARE REMOUED. (1) WATER H2O 


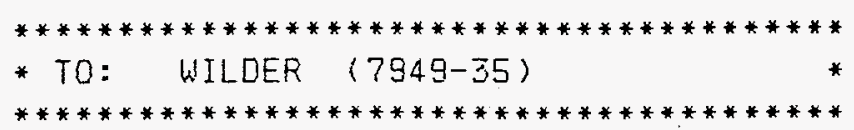

\#2

MASS SPECTROMETRIC ANALYSIS NO. 12580.

DONE ON 27 SEP 93 AT 12:39:40 CALCULATED ON 29-SEP-93 AT 08:34

COMPOUND

CONCENTRATION STO DEV.

MOLE (UOLUME) PCT.

\begin{abstract}
NITROGEN
OXYGEN

ARGON

CARBON DIOXIDE
\end{abstract}

TOTAL

$$
\begin{aligned}
& \text { N2 . . . } 80.770 .11 \\
& 02 . . \quad 10.87 \quad 0.02 \\
& \text { AR . . . } 0.8910 .002 \\
& \mathrm{CO2} \cdot . .7 .465 \quad 0.014 \\
& === \pm==
\end{aligned}
$$

VARIANCE $=0.55$ PERCENT

NOTE: UNCERTAINTIES ARE ONE STD. DEV. FROM THE 'REGRESSION, ANALYSIS AND DO NOT INCLUDE CONTRIBUTIONS DUE TO INTENSITY MEASUREMENTS WHICH ADD ABOUT $+/-.2 \%$ 'OF THE. CONCENTRATION.

COMPUTED UALUES LESS THAN 0.01 PERCENT HAUE BEEN OMITTED.

COMPONENTS OMITTED EQUAL TO 0.14 PERCENT OF THE SAMPLE

RESULTS ARE NORMALIZED' AFTER THESE COMPOUNDS ARE REMOUED. (1) WATER H2O 


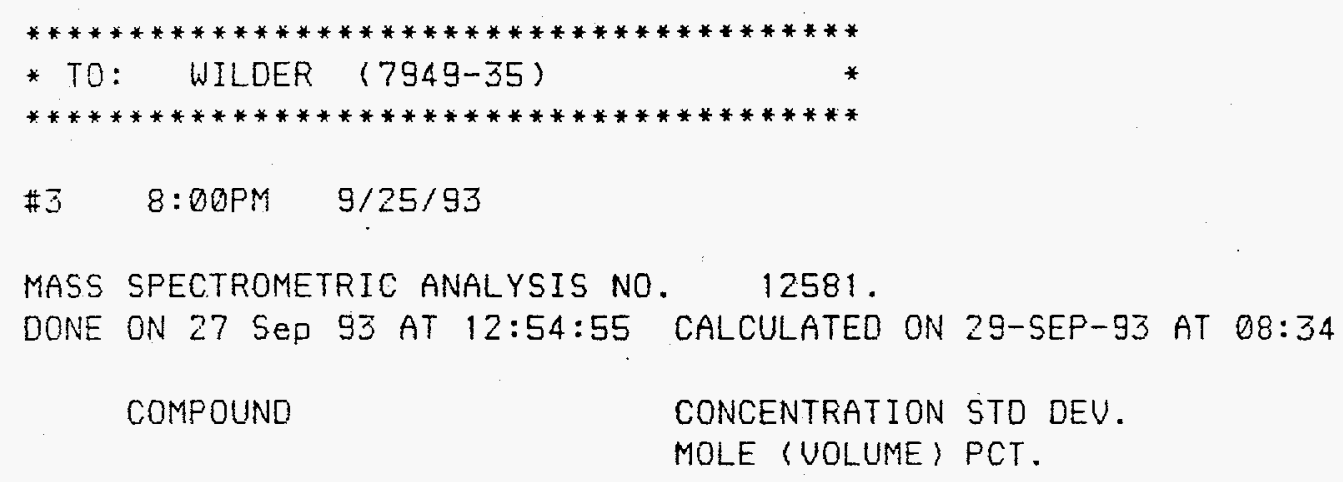

NOTE: UNCERTAINTIES ARE ONE STD. DEU. FROM THE 'REGRESSION, ANALYSIS AND DO NOT INCLUDE CONTRIBUTIONS DUE TO INTENSITY MEASUREMENTS WHICH ADO ABOUT $+/-.2 \%$ OF THE. CONCENTRATION.

COMPUTEO VALUES LESS THAN 0.01 PERCENT HaVE BEEN OMITTED.

COMPONENTS OMITTED EQUAL TO 0.19 PERCENT OF THE SAMPLE

RESULTS ARE NORMALIZED' AFTER THESE COMPOUNDS ARE REMOUED. (1) WATER HZO 


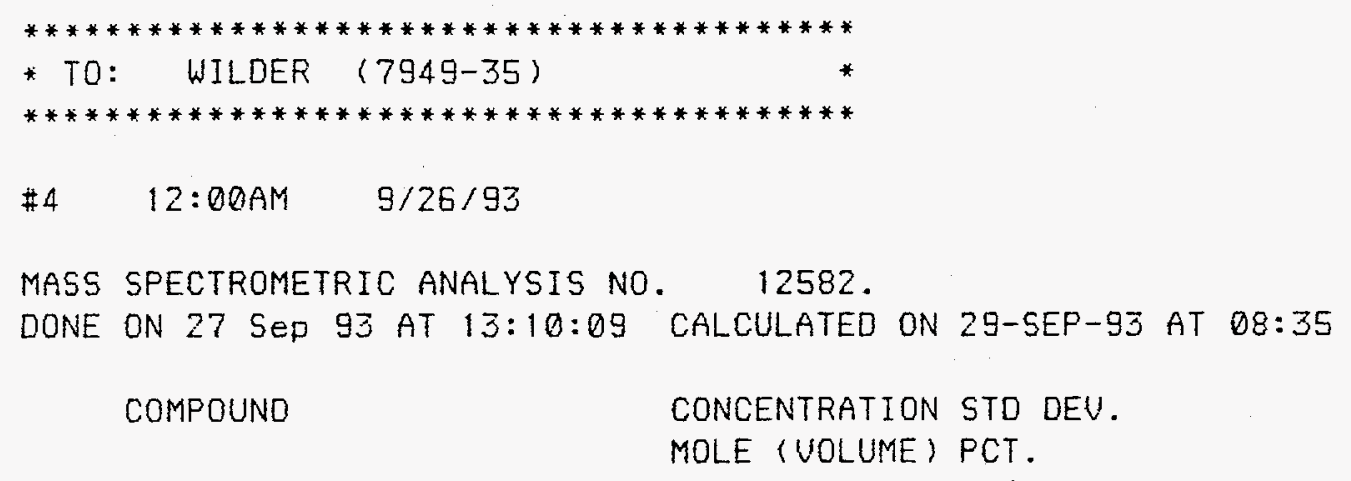

NOTE: UNCERTAINTIES ARE ONE STD. DEV. FROM THE 'REGRESSION, ANALYSIS AND DO NOT INCLUDE CONTRIBUTIONS DUE TO

INTENSITY MEASUREMENTS WHICH ADD ABOUT $+1-.2 \%$ OF THE. CONCENTRATION.

COMPUTEO VALUES LESS THAN 0.01 PERCENT HAVE BEEN OMITTED.

COMPONENTS OMITTED EQUAL TO 0.25 PERCENT OF THE SAMPLE

RESULTS ARE NORMALIZED' AFTER THESE COMPOUNDS ARE REMOVED.

$$
\text { (1) WATER H2O }
$$




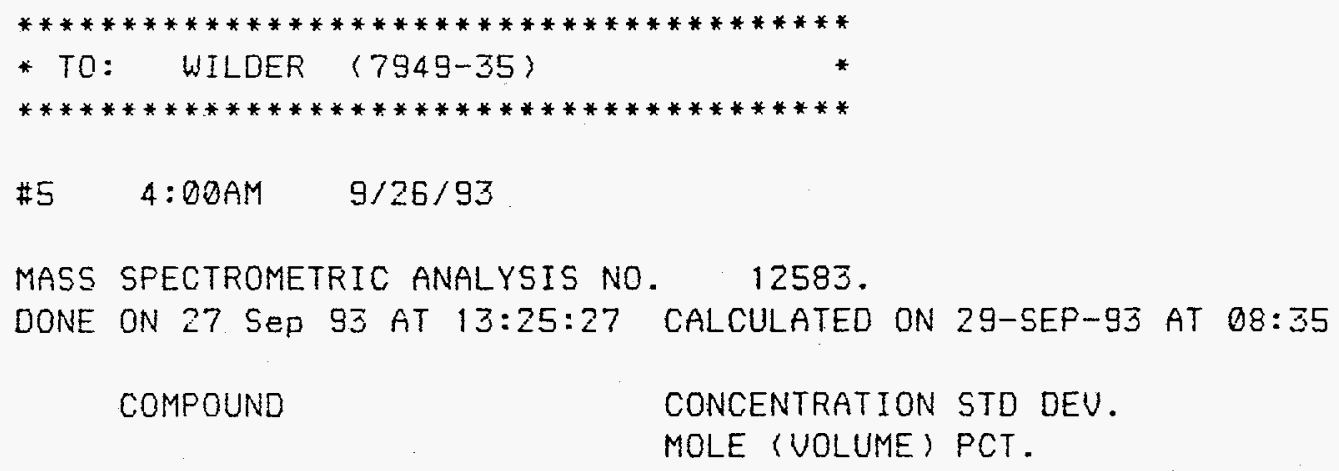

NOTE: UNCERTAINTIES ARE ONE STD. DEV. FROM THE 'REGRESSION, ANALYSIS AND DO NOT INCLUDE CONTRIBUTIONS DUE TO

INTENSITY MEASUREMENTS WHICH ADD ABOUT $+1-.2 \%$ 'OF THE. CONCENTRATION.

COMPUTED VALUES LESS THAN 0.01 PERCENT HAVE BEEN OMITTED.

COMPONENTS OMITTED EQUAL TO 0.33 PERCENT OF THE SAMPLE

RESULTS ARE NORMALIZED' AFTER THESE COMPOUNDS ARE REMOUED.

(1) WATER H2O 


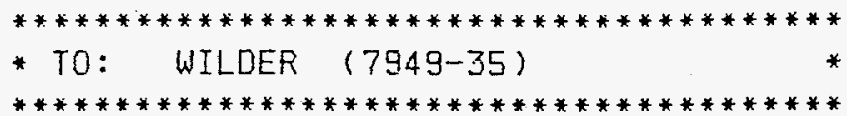

\#5 8:00AM $9 / 26 / 93$

MASS SPECTROMETRIC ANALYSIS NO. 12584.

DONE ON 27 SEP 93 AT 13:40:42 CALCULATED ON 29-SEP-93 AT OB:3E

COMPOUND

CONCENTRATION STO DEU. MOLE (UOLUME) PCT.

NITROGEN
OXYGEN
ARGON
CARBON DIOXIDE

TOTAL

$$
\begin{aligned}
& \text { N2..... } 80.810 .04 \\
& 02 . . \quad .0 .191009 \\
& \text { AR . . . . } 0.8970 .001 \\
& \mathrm{CO2} . . . \quad 8.085 \quad 0.006 \\
& ===== \\
& 99.98
\end{aligned}
$$

NOTE: UNCERTAINTIES ARE ONE STD. DEU. FROM THE :REGRESSION, ANALYSIS AND DO NOT INCLUDE CONTRIBUTIONS DUE TO

INTENSITY MEASUREMENTS WHICH ADD ABOUT $+/-.2 \%$ OF THE. CONCENTRATION.

COMPUTED VALUES LESS THAN 0.01 PERCENT HAVE BEEN OMITTED.

COMPONENTS OMITTED EQUAL TO 0.28 PERCENT OF THE SAMPLE

RESULTS ARE NORMALIZED' AFTER THESE COMPOUNDS ARE REMOVED. (1) WATER H2O 
Two Stage Molten Salt B-241 27 Sep 93 Run MSD:DATA:27 Sep 93 Run TIMING REFERENCES-- VAX Time = 27-SEP-1993 19:18:49.00, Decimal Hours = 19.3136111

9/27/93 7:23:38 PM 19.393907 This is another atempt to run 100 hours. We have installed wire brush cleaning devices on the exhaust riser of each vessel. The plan is to sweep the risers at periodic intervals to keep them clear. During the initial startup, the lower heating element of vessel \#1 shorted and welded itself to the lower thermocouple well. The "weld" was broken. The system seems to be working.

9/27/93 8:30:28 PM 20.510593 Initial temperature on vessel one had to be raised quite high in order to free a salt plug in the injector tube. I will cool the vessel down a bit before starting the rubber feed.

9/27/93 8:34:42 PM 20.581306 Begin rubber feed. Feed rate is estimated to be about $3.0 \mathrm{~g} / \mathrm{min}$.

$\begin{array}{llll}\text { 9/27/93 } & 10: 00: 02 \text { PM } & 22.007032 & \text { Removed sample \#8. B.B. } \\ \text { 9/27/93 } & 10: 21: 29 \text { PM } & 22.365495 & \text { Raised temp. to 729 10:25 pm B.B. }\end{array}$

9/27/93 11:04:44 PM 23.088167 Stopped rubber feed and combustion air momentarily to "scrub" both riser with the new brushs. All worked well. Restarted combustion air and rubber feed with same conditions as before.

9/28/93 12:13:26 AM 24.235745 Corrie, the time scale of the data charts has gone completely ape. What happened?

9/28/93 12:14:58 AM 24.261444 Take gas sample \#9.

9/28/93 3:33:43 AM 27.581958 This is a demonstration for Curly.

9/28/93 3:44:32 AM 27.762940 Shut down fuel and combustion air for a short time to scrape the two risers for the second time. They appear to be clear. Restarted air and fuel as before.

9/28/93

$9 / 28 / 93$

$9 / 28 / 93$

9/28/93

4:45:58 AM 28.789148

PROB

9/28/93

$9 / 28 / 93$

9/28/93

help. Horizontal run?

3:47:08 AM 27.805940

4:05:17 AM 28.109412

4:14:44 AM 28.267245

Added two bottles of rubber to hopper.

Took gas sample \#10

Rubber feed plugged during last gas sample

Plugged feed $10 \mathrm{~min}$ ago

WITH COMPUTER -OPERATER ERROR

5:15:40 AM 29.285426

Fuel feed plugged $5 \mathrm{~min}$ ago

5:51:16 AM 29.880218

CAMAC restarted

P2 above 15psi, cleared both risers but did not

Will wait for Doug and see what he says.

9/28/93

7:50:28 AM 31.871866

Bumped set point up to $750 \mathrm{c}$.

9/28/93

8:03:30 AM 32.089639

Pressure up to 15.25psi HOPE Doug gets here

SOON !

9/28/93

8:25:08 AM 32.450620

Sample \#11 taken at 0820 .

Risers have been swept with wire brush, but pressure still rising slowly. The horizontal section is apparently filling with salt again.

9/28/93 8:33:35 AM 32.592097 At 0830, opened tap below pressure tap and rodded material out, pressure dropped. When tap was closed, pressure went back up. 9/28/93 9:45:24 AM 33.792000 Unexpected rise in pressures one and two. Stop experiment. Will determine cause.

9/28/93 9:47:45 AM 33.831157 This is a test. 
9/28/93 11:01:38 AM 35.065685 The system pressure began to rise, so it was shut down for inspection. We found no evidence of blockage anywhere! We've reassembled the exhaust lines and are waiting for the salt temperature to return to the previous settings prior to continuance.

9/28/93 11:10:05 AM 35.206907 Begin feed. Temperatures are a bit low, but it is hoped that the burning rubber will accelerate the warmup.

9/28/93 11:11:39 AM $\quad 35.232907$ Secured vessel one top heater.

9/28/93 11:16:15 AM 35.310005 Two jars of rubber were added prior to this resumption of fuel feed.

9/28/93 11:36:42 AM 35.651685 Power reading to the lower heater of vessel one is $72 \%$, as compared to $48 \%$ earlier, yet the salt temperature appears to have

stabilized at under $700^{\circ} \mathrm{C}$. The pressure has stabilized (for now) at about $15.1 \mathrm{psi}$ though I find no indication of blockage anywhere. We are further plagued by the PrintMonitor feature of this Mac no wanting to go away.

9/28/93 11:50:41 AM 35.885088 I'm beginning to believe that the recent abnormalities in pressure just may be caused by faulty readings. They may bear little resemblence to reality.

9/28/93 12:02:43 PM

9/28/93 12:06:22 PM

9/28/93 12:06:35 PM

9/28/93 12:10:35 PM

9/28/93 12:10:57 PM

9/28/93 12:26:58 PM

36.086370

36.147102

36.150532

36.217792

36.223463

36.491523 Run secured due to salt blockage at the riser/top junction in vessel \#1. This blockage could not be dislodged with the brush. It appears as if it formed very fast. 


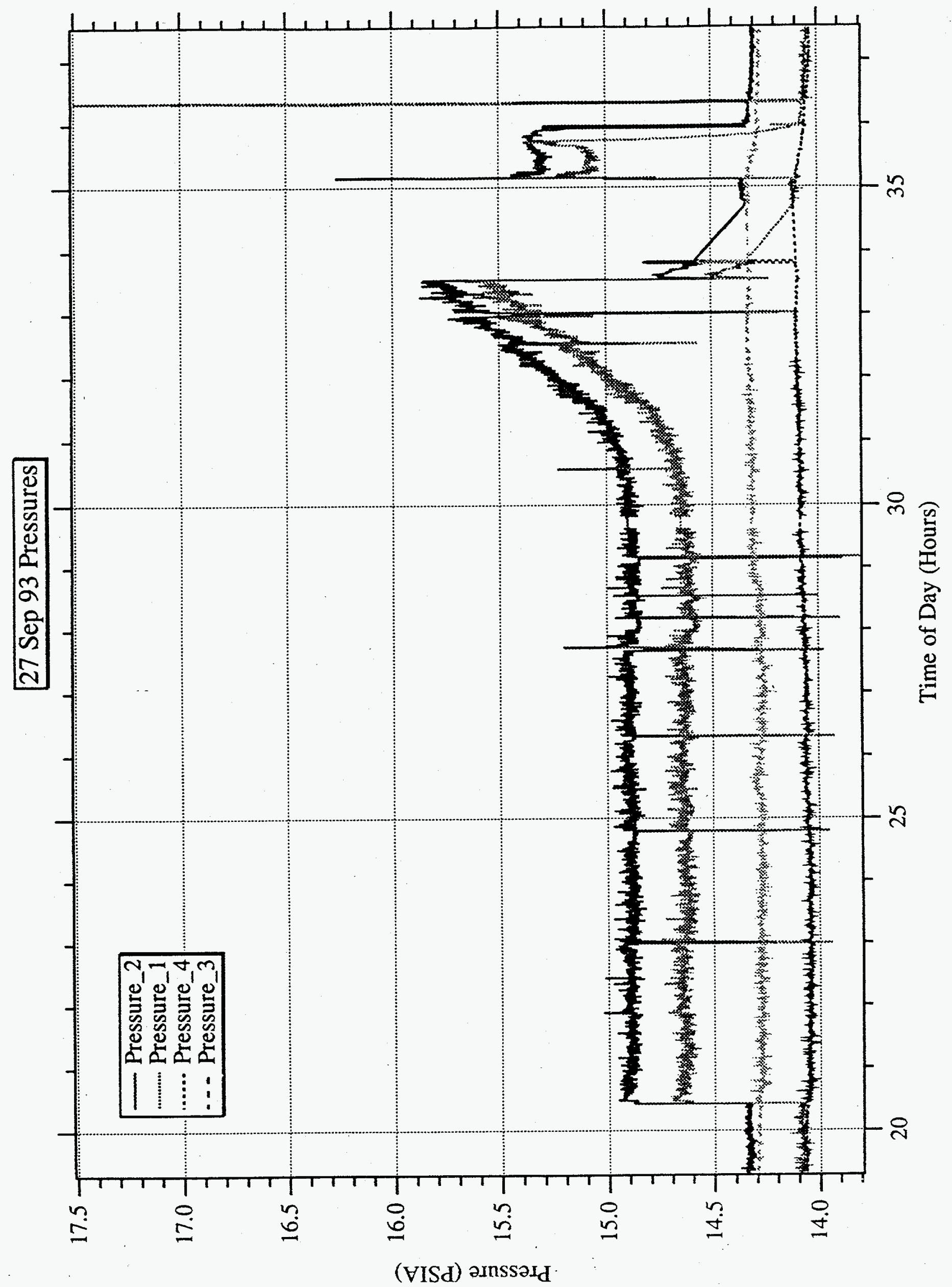




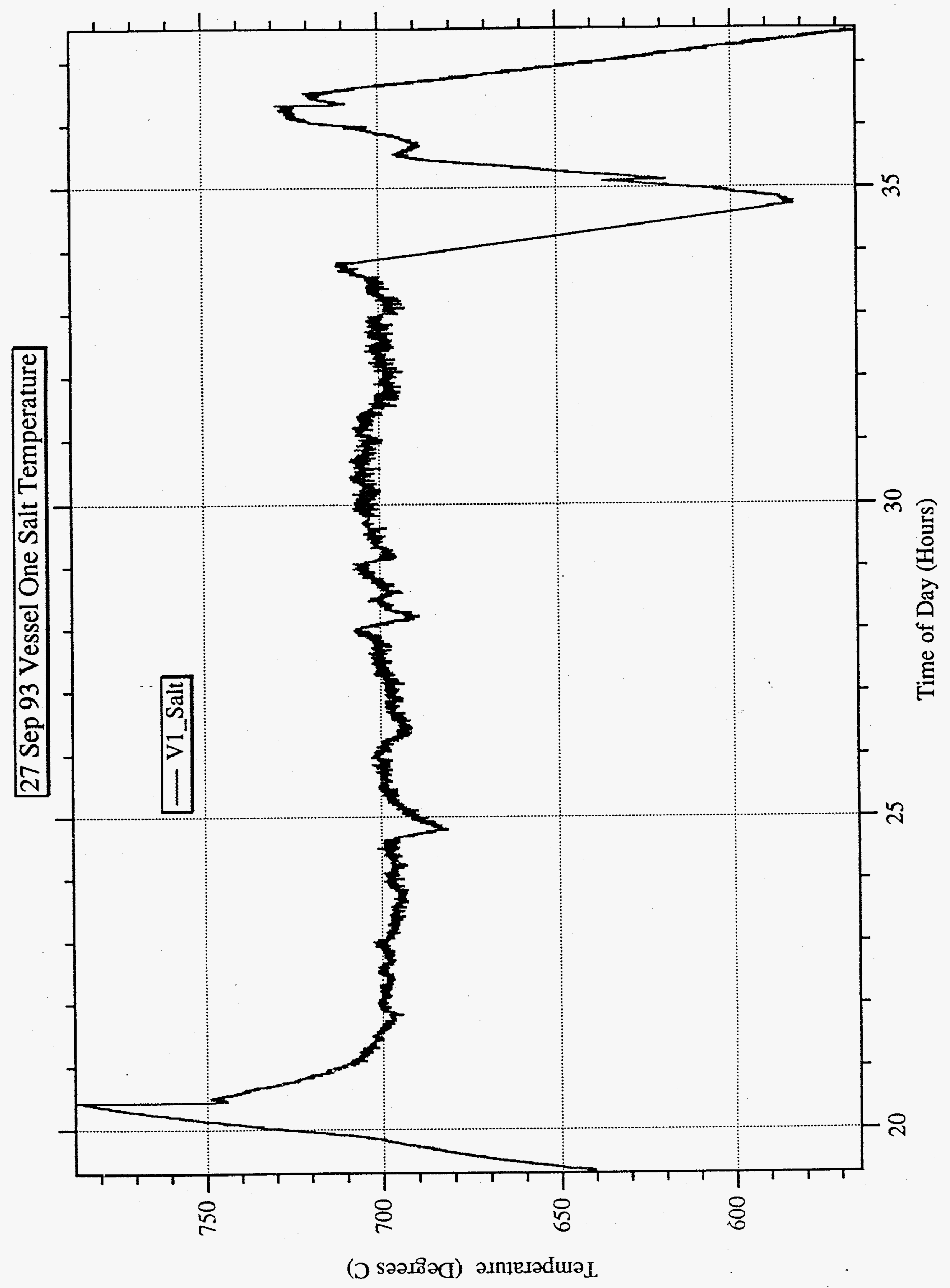




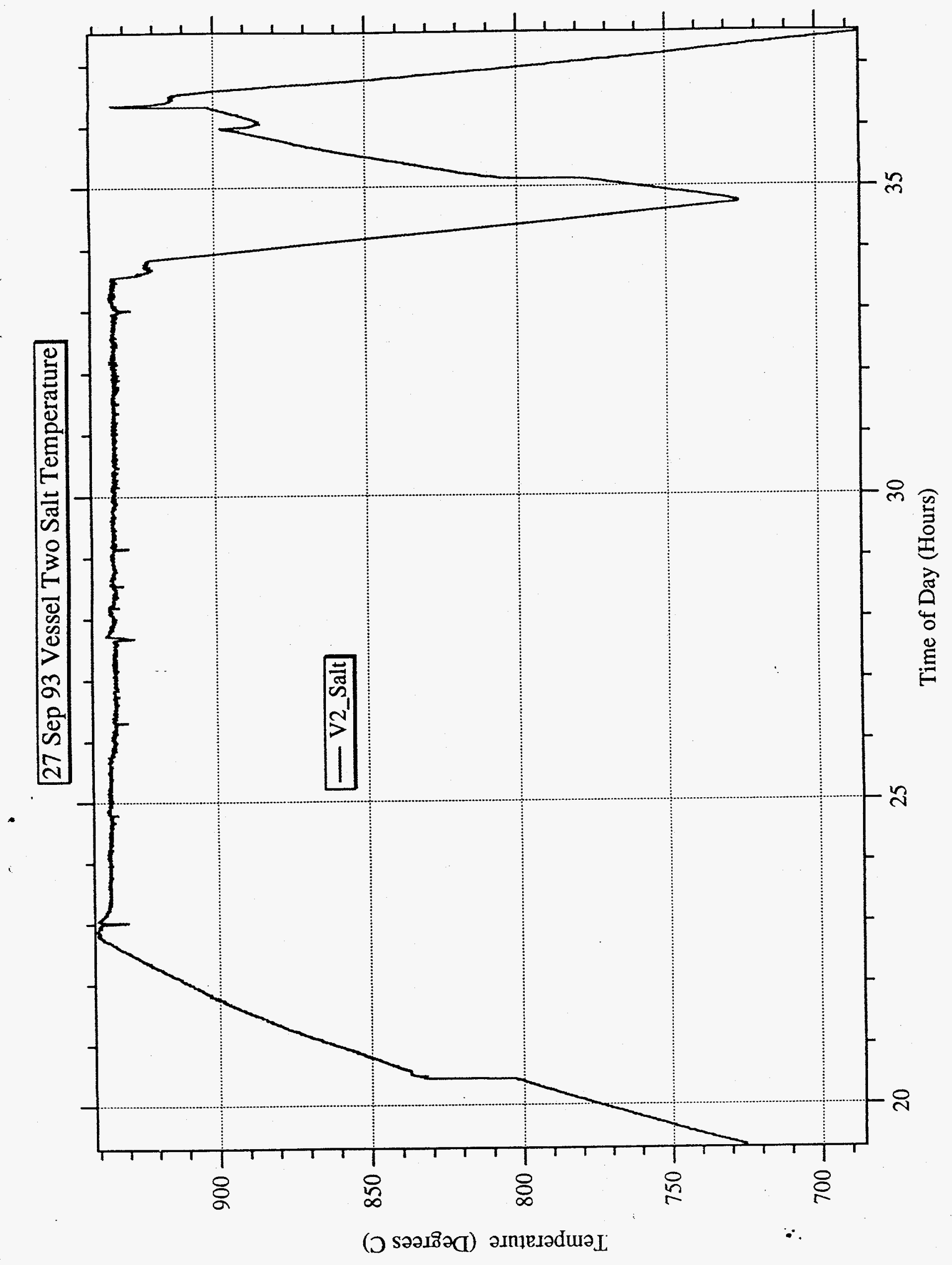




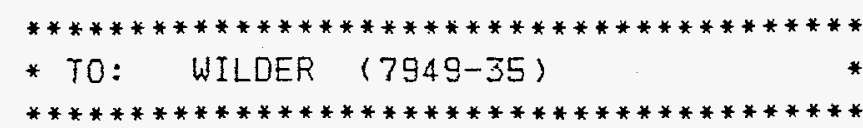

8

MASS SPECTROMETRIC ANALYSIS NO. 12613.

DONE ON 29 SEP 93 AT 15:19:20 CALCULATED ON 30-SEP-93 AT 08:25

COMPOUND

CONCENTRATION STD DEV. MOLE (VOLUME) PCT.

NITROGEN
OXYGEN
ARGON
CARBON DIOXIDE
NITROUS OXIDE

TOTAL

$$
\begin{aligned}
& \text { N2. . . } 79.780 .26 \\
& 02 . . . .11 .45 \quad 0.05 \\
& \text { AR .... } 0.9310 .004 \\
& \mathrm{CO} 2 . . . \quad 7.77 \quad 0.05 \\
& \text { N2O . . } 0.06 \quad 0.02 \\
& ====== \\
& 100.00
\end{aligned}
$$

UARIANCE $=1.13$ PERCENT

NOTE: UNCERTAINTIES ARE ONE STD. DEU. FROM THE 'REGRESSION, ANALYSIS AND DO NOT INCLUDE CONTRIBUTIONS DUE TO INTENSITY MEASUREMENTS WHICH ADD ABOUT $+1-.2 \%$ OF THE. CONCENTRATION.

COMPUTED VALUES LESS THAN 0.01 PERCENT HAUE BEEN OMITTED.

COMFONENTS OMITTEO EQUAL TO 0.03 PERCENT OF THE SAMFLE RESULTS ARE NORMALIZED' AFTER THESE COMPOUNDS ARE REMOUED. (1) WATER H2O 
* TO: WILDER (7949-35) *

$* * * * * * * * * * * * * * * * * * * * * * * * * * * * * * * *$

9

MASS SPECTROMETRIC ANALYSIS NO. 12614.

DONE ON 29 Sep 93 AT 15:34:41 CALCULATED ON 30-SEP-93 AT 08:41

COMPOUND CONCENTRATION STD DEU. MOLE (VOLUNE) PCT.

1
$-\quad 2$
3
4
5

\begin{abstract}
NITROGEN
OXYGEN

ARGON

CARBON DIOXIDE
\end{abstract}

NITROGEN DIOXIDE NO2

TOTAL

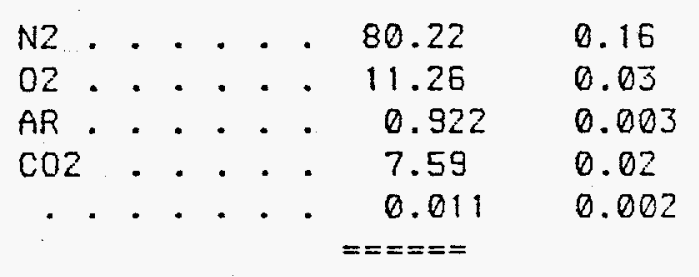

100.00

VARIANCE $=0.78$ PERCENT

NOTE: UNCERTAINTIES ARE ONE STD. DEU. FROM THE 'REGRESSION, ANALYSIS AND DO NOT INCLUDE CONTRIBUTIONS DUE TO

INTENSITY MEASUREMENTS WHICH ADO ABOUT $+1-.2 \%$ 'OF THE. CONCENTRATION.

COMPUTED VALUES LESS THAN 0.01 PERCENT HAVE BEEN OMITTED.

COMPONENTS OMITTED EQUAL TO 0.14 PERCENT OF THE SAMPLE

RESULTS ARE NORMALIZED' AFTEF. THESE COMPOUNDS ARE REMOVED.

(1) WATER H2O 
* TO:

WILDER

$(7949-35)$

10

NASS SPECTROMETRIC ANALYSIS NO. 12615.

DONE ON 29 SEP 93 AT 15:50:03 CALCULATED ON 30-SEP-93 AT 08:41

COMPOUND

CONCENTRATION STD DEU.

MOLE (VOLUME) PCT.

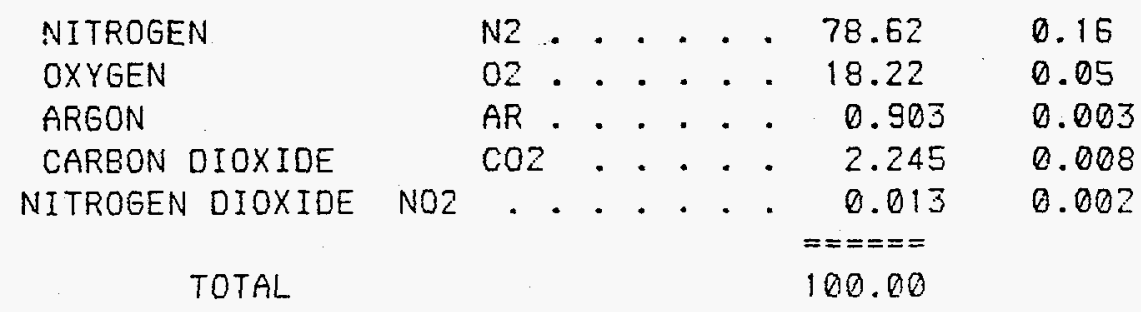

VARIANCE $=0.84$ PERCENT

NOTE: UNCEFTAINTIES ARE ONE STD. DEU. FROM THE 'REGRESSION, ANALYSIS AND DO NOT INCLUDE CONTRIBUTIONS DUE TO

INTENSITY MEASUREMENTS WHICH ADD ABOUT $+i-.2 \%$ 'OF THE. CONCENTRATION.

COMPUTED VALUES LESS THAN 0.01 PERCENT HAUE BEEN OMITTED.

COMPONENTS OMITTED EQUAL TO 0.12 PERCENT OF THE SAMPLE

RESULTS ARE NORMALIZEO' AFTER THESE COMPOUNDS ARE REMOUED.

(1) WATER H2O 